\title{
ROZPRAWY
}

\section{Donos na dominikanina \\ Studium historyczne i edycja tekstu listu denuncjacyjnego Stanisława ze Skarbimierza i akt sprawy brata Mikołaja z Brześcia z około 1421 roku*}

\section{Pamięci Profesorów Stanisława Byliny i Jerzego Kłoczowskiego}

Zarys treści: Artykuł dotyczy procesu denuncjacyjnego przeciwko byłemu prowincjałowi dominikanów krakowskich Mikołajowi z Brzezia z około 1421 r. Jego kazania oburzyły krakowskich duchownych, których prokuratorem stał się Stanisław ze Skarbimierza. Sprawa stanowi odbicie napięć związanych z poczuciem zagrożenia przez husytyzm.

Content outline: The paper deals with the denunciatory proceedings against the former provincial of the Cracovian Dominicans, Mikołaj of Brzezie, in circa 1421. His sermons outraged the clergy of Cracow, whose procurator became Stanisław of Skarbimierz. The matter reflects the tensions connected with the feeling of the threat of Hussitism.

Słowa kluczowe: Stanisław ze Skarbimierza, dominikanie, prowincjał Mikołaj z Brześcia, Wojciech Jastrzębiec, Uniwersytet Krakowski, husytyzm, wiklefizm, proces denuncjacyjny, kaznodziejstwo, inkwizycja

Keywords: Stanisław of Skarbimierz, Dominicans, provincial Mikołaj of Brześć, Wojciech Jastrzębiec, Cracow University, Hussitism, Wiclifism, denunciatory process, medieval preaching, Inquisition

\section{WSTĘP}

Na początku lat pięćdziesiątych XX w. prof. Zofia Kozłowska-Budkowa, w trakcie prac nad średniowiecznymi zbiorami kazań uniwersyteckich przechowywanych w zbiorach rękopiśmiennych Biblioteki Jagiellońskiej w Krakowie, natrafiła na niewielki tekst dopisany na ostatnich kartach rękopisu BJ 1629. Ponieważ w źródle pojawiła się postać jakiegoś dominikanina, o swoim odkryciu poinformowała więc świeżo wypromowanego dr. Jerzego Kłoczowskiego, przygotowującego wówczas do druku monografię o dominikanach śląskich. Ten - przytaczając opis sporządzony

* Praca została napisana w ramach projektu nr 2014/13/B/HS3/04911, finansowanego ze środków przyznanych przez Narodowe Centrum Nauki. 
przez krakowską mediewistkę - wspomniał o tym tekście w obszernym przypisie, dotyczącym szkolnictwa dominikańskiego i zakonnego studium generalnego. Czytamy tam m.in.: „Rkp. Bibl. Jagiell. nr 1629 k. 340-341r zawiera np. list dotyczący oskarżenia brata N., dominikanina, o wygłaszanie w kazaniach błędnych i szkodliwych twierdzeń i żądających ich odwołania. Rękopis pochodzi z kolegium kanonistów z 1417 r. i zawiera przede wszystkim kazania. Wspomniany wyżej list wpisany został na stronach, które pozostały puste, ręką niewiele późniejszą od ręki z 1417 r. Wśród punktów oskarżenia kaznodziei dominikańskiego na szczególną uwagę zasługuje czwarty zarzucający wręcz zakonowi wrogie wystąpienie przeciwko uniwersytetowi”'. Według J. Kłoczowskiego wspomniane źródło wzmacniało hipotezę o trudnych relacjach, a nawet „walce” pomiędzy dominikańskim a uniwersyteckim ośrodkiem studiów wyższych. Interpretacja ta została zaakceptowana przez Macieja Zdanka, który uznał tekst z rękopisu BJ 1629 za „świadectwo rzeczywistego napięcia” między dominikanami a Wydziałem Teologicznym². Ostatnio Wojciech Świeboda odnalazł w rękopisie BJ 1652 drugą kopię wspomnianego tekstu i przekazał mi ją do opracowania ${ }^{3}$. Lektura i dokładna analiza obu kodeksów była nad wyraz owocna i zaskakująca. Okazało się bowiem, że rękopisy te zawierają nie tylko jakiś „list”, ale grupę kilku powiązanych ze sobą tekstów. Głównym tematem jest obszerna denuncjacja złożona przez nieznanego autora do nieznanego wysokiego urzędnika kościelnego przeciwko pewnemu kaznodziei dominikańskiemu Mikołajowi, który miał obrażać lokalne duchowieństwo i profesorów uniwersyteckich oraz głosić treści sprzeczne z doktryną Kościoła. Do denuncjacji dołączono również dwa pisma, dłuższe i krótsze, zawierające odpowiedzi dominikanina na dziewięć zarzutów. Teksty te nie są datowane. Widzimy zatem, że liczba niewiadomych i pytań jest długa: Jaka jest wiarygodność przekazów i jakie są pomiędzy nimi relacje? Kiedy powstały te trzy teksty i jaki jest ich charakter? Czy był to zwyczajny donos czy też element jakiejś procedury sądowej? Kim byli sprawca denuncjacji oraz zadenuncjowany zakonnik? Jakie były okoliczności i powody złożenia doniesienia? Jakie zarzuty zostały postawione dominikaninowi i jaka była jego reakcja? Odpowiedzi na powyższe oraz wiele innych pytań postaram się przedstawić w niniejszym studium. W aneksie udostępniam zaś edycję analizowanych tekstów.

\section{TRADYCJA RĘKOPIŚMIENNA I KRYTYKA TEKSTU}

Tradycja rękopiśmienna omawianego źródła obejmuje dwa piętnastowieczne przekazy rękopiśmienne: BJ 1629 i BJ 1652. Żaden z nich nie doczekał się jeszcze gruntownego opracowania katalogowego. Stosunkowo najlepiej w literaturze przedmiotu rozpoznany został rękopis BJ 1629 (dalej: Kr1) ${ }^{4}$. Ma wymiary 30,5 x 22 cm,

1 J. Kło c zow ski, Dominikanie polscy na Śląsku w XIII-XIV wieku, Lublin 1956, s. 233 , przyp. 1.

${ }^{2}$ M. Z d a n e k, Szkoły i studia dominikanów krakowskich w średniowieczu, Warszawa 2005, s. 126.

3 Serdecznie dziękuję Panu dr. Wojciechowi Świebodzie z Oddziału Rekopisów Biblioteki Jagiellońskiej w Krakowie za udostępnienie mi źródeł oraz życzliwą pomoc.

${ }^{4}$ W. W i s ł o c k i, Katalog rękopisów Biblioteki Uniwersytetu Jagiellońskiego, t. I, Kraków1877-1881, s. 394-395; Z. B u d k o w a, Rękopisy kazania „De bellis iustis”, w: L. Ehrlich, 
zawiera 341 kart papierowych oraz 3 pergaminowe (k. I-III); papier z sześcioma różnymi znakami wodnymi pochodzi z lat 1414-1417. Rękopis zawiera: kazania sapiencjalne Stanisława ze Skarbimierza (k. 1r-304r) oraz przypisywaną mu rektorską mowę rekomendacyjną (k. 333v-336r), ponadto dwa anonimowe traktaty teologiczne (k. 305r-339r), interesującą nas anonimową denuncjację w sprawie poglądów dominikanina, brata N., i jego konkluzje (k. 340v-341r), uwagi o grzechach i zasługach oraz wróżbach i wróżbitach (k. 342v). Prawie cały rękopis (k. 1r-304r, 333v-336r) przepisał jeden nieznany skądinąd kopista Michał w marcu 1417 r., o czym poinformował w kolofonie (k. 293r). W powstaniu rękopisu uczestniczyło jeszcze trzech innych kopistów (drugi zapisał k. 305r-333r, trzeci - k. 336r-339r, a czwarty - k. 340v-341r, IIIr-v), którzy przystąpili do pracy po marcu 1417 r. i zakończyli ją prawdopodobnie w krótkim czasie. Datację tę potwierdza również analiza kodykologiczna fragmentu rękopisu, zawierającego interesujący nas tekst. Został on zapisany przez czwartego kopistę drobną kursywą gotycką, w jednym bloku tekstu, na ostatniej stronie ostatniej składki (seksternion, k. 324-340) oraz na doszytej do tej składki karcie 341. Warto zauważyć, że ostatnia składka została złożona z papieru z znakiem wodnym z 1417 r., przedstawiającym głowę wołu z różą na pojedynczym pręcie ${ }^{5}$. Z kolei dodana k. 341 nosi inny znak wodny z 1416 r. - rogi wołu z gwiazdą na pojedynczym pręcie ${ }^{6}$; ten sam znak odnajdujemy również na kartach innych składek ${ }^{7}$. Czwarty kopista zatem użył tego samego papieru, z którego skorzystał pierwszy, rozpoczynający przed marcem 1417 r. przepisywanie kazań sapiencjalnych Stanisława ze Skarbimierza. Można domniemywać, że gdyby interesujący nas tekst z k. 340v-341r został skopiowany dużo później niż reszta rękopisu Kr1, czwarty kopista z pewnością skorzystałby z papieru o zupełnie innej proweniencji. Obserwacja ta jest o tyle istotna, że daje mocne podstawy, by powstanie omawianego źródła datować niedługo po $1417 \mathrm{r}$. Potwierdza to przypuszczenie Zofii Budkowej, że omawiany tekst został sporządzony „ręką nie wiele późniejszą od ręki z 1417 r.”8

Rękopis BJ 1652 (dalej: Kr2) ma wymiary 30,5 × 21,5 cm, spisany został na paginowanych papierowych składkach, noszących sześć rodzajów znaków wodnych z lat 1377-13909. Kodeks zawiera drugą część dzieła Expositio super totum corpus Evangeliorum, autorstwa czternastowiecznego augustianina Szymona Fidati (s. 1-521) oraz wspomnianą denuncjację w sprawie poglądów dominikanina, brata Mikołaja i jego odpowiedzi (s. 521-524). Rękopis został skopiowany przez trzech kopistów: imię pierwszego (który zapisał s. 1-343) znamy z kolofonu (s. 163); był

Polski wykład prawa wojny XV wieku. Kazanie Stanisława ze Skarbimierza „De bellis iustis”, Warszawa 1955, s. 222; C. Z a w o d z i ń s k a, Pisma Stanisława ze Skarbimierza, pierwszego rektora UJ, w kodeksach Biblioteki Jagiellońskiej, Roczniki Biblioteczne 4, 1960, s. 320; R. Z a w a d zk i, Spuścizna pisarska Stanisława ze Skarbimierza, Kraków 1979, s. 38; Stanisław ze Skarbimierza, Sermones sapienciales, t. I, wyd. B. Chmielowska, Warszawa 1979, s. 16-17.

${ }_{5}^{5}$ Piccard online (<https://www.piccard-online.de/start.php $>$ ), $\mathrm{nr} 65667$.

${ }_{6}^{6}$ Tamże, nr 61807.

7 BJ 1629, k. 15, 18, 20-21, 23-25, 31-35, 37, 41, 43, 45-47, 97, 101, 103, 105-107.

${ }^{8}$ Zob. przyp. 1.

${ }^{9}$ W. W i s ł o c k i, Katalog, t. I, s. 399; Z. K o zło w s k a - B u d k o w a, Opis rękopisu BJ 1652 (maszynopis w Oddziale Rękopisów BJ), s. 5. 
to Iohannes filius Wenceslaiy medici de Chremsir dictus Hana; drugi, anonimowy pisarz (s. 343-521) sporządził również powstały pod koniec XIV w. rękopis BJ 1657 z pierwszą częścią dzieła Szymona Fidati ${ }^{10}$; trzeci kopista dopisał później interesującą nas denuncjację i odpowiedzi na nią (s. 521-524). Pisał staranną kursywą gotycką na ostatniej składce rękopisu (kwinternion, s. 507-526). Papier tej składki nosi znak głowy jelenia i datowany jest na lata osiemdziesiąte XIV w. ${ }^{11}$ Ten sam typ papieru odnajdujemy także na s. 153-180. Warto zauważyć, że w oprawach tego rękopisu znajdują się cztery dokumenty odnoszące się do spraw czeskich, m.in. list Jana I księcia opawskiego i raciborskiego z 1381 r. Najprawdopodobniej rękopis ten został złożony i oprawiony na przełomie XIV i XV w. Z. Kozłowska-Budkowa, bazując na informacjach z kolofonu oraz wyklejek, zaproponowała jego czeską proweniencję. Niestety, na tym etapie badań nie jesteśmy w stanie dokładnie określić czasu i okoliczności skopiowania przez trzeciego pisarza krakowskiego pisma.

Ponieważ treść denuncjacji zostanie omówiona w dalszej części studium, dlatego też krytykę tekstu rozpocznę od opisu struktury tego zawiadomienia. Krakowska denuncjacja ma formę listu denuncjacyjnego (litterae denuntiationis) i składa się z czterech formuł: 1) salutacja; 2) prolog; 3) narracja, w której przedstawiono zarzuty przeciwko dominikaninowi oraz opinię prawno-teologiczną; 4) petycja, zachęcająca adresata do podjęcia odpowiednich czynności. Formuła datacyjna oraz podpis wystawcy nie zostały zanotowane przez żadnego z kopistów. Wszystkie z wymienionych czterech formuł odnajdujemy tylko w rękopisie Kr1. W Kr2 brakuje petycji, po obszernej narracji przechodzi się od razu do prezentacji odpowiedzi dominikanina. Opustka ta z pewnością była wynikiem albo świadomej decyzji pisarza Kr2, albo braku tego elementu struktury w pierwowzorze, z którego on korzystał. Z pewnością petycja nie była autorskim dodatkiem kopisty Krl. W świetle tej obserwacji, możemy sformułować pierwszy wniosek: pisarz Kr1 nie skopiował tekstu z rękopisu Kr2. Definitywnym potwierdzeniem tej obserwacji jest zidentyfikowanie w Kr2 jednej opustki uwarunkowanej kontekstem (per homoeoteleuton) w stosunku do Kr1. Czy w takim razie pierwowzorem Kr2 był tekst denuncjacji przekazany w Kr1? Taką możliwość wykluczają przynajmniej dwa argumenty. Kopista Kr1 opuścił, zapewne nieświadomie, krótki (pochodzący z dzieła Ryszarda z Middletown) fragment tekstu (non conuenit), który jest w Kr2. Ponadto Kr2 zachował też- inaczej niż Kr1 - poprawną lekcję w cytacie ze św. Hieronima: qui uel se uel (et Kr1) mundum lugeat. Kopista $\mathrm{Kr} 2$ nie skopiował więc tekstu z rękopisu Kr1. Czy zatem obaj kopiści korzystali z tego samego pierwowzoru tekstu denuncjacji? W trakcie krytyki tekstu odnajdujemy przynajmniej cztery argumenty uwiarygodniające możliwość istnienia wspólnego pierwowzoru. Po pierwsze, oba rękopisy posiadają tę samą błędną lekcję: minister paucis, zamiast zgodnej z logiką wywodu: minister pacis. Błędu tego zapewne nie było w czystopisie listu denuncjacyjnego, ale pojawił się dopiero w jego kopii (lub brudnopisie listu), będącej pierwowzorem dla pisarzy rękopisów Kr1 i Kr2. Przypuszczenie to potwierdza także druga obserwacja. Obaj kopiści świadomie pozostawili w środku tekstu puste miejsce na wpisanie brakującego około ośmioliterowego słowa

${ }^{10}$ W. W i s ł o c k i, Katalog, t. I, s. 400.

${ }^{11}$ Piccard online, $\mathrm{nr} 85662$. 
(uocantur). Możemy się domyślać, że kopista pierwowzoru nie potrafił odczytać tego słowa w przepisywanym tekście, dlatego też je opuścił, planując być może późniejszą korektę. W końcu, argumentem na rzecz jednego pierwowzoru jest brak poważniejszych różnic tekstowych pomiędzy kopiami. Rękopis $\mathrm{Kr} 2$, oprócz przytoczonej już opustki per homoeoteleuton i braku końcowej petycji, nie ma żadnych innych pominięć w stosunku do Kr1. Z kolei w Kr1 zidentyfikowano jedynie dwie drobne opustki, jedną inwersję dwóch słów i jeden nieznaczący wariant tekstowy. Ostatnim argumentem na rzecz jednego pierwowozoru jest zasygnalizowane już pominięcie przez obu kopistów formuły datacyjnej oraz podpisu wystawcy. Opustkę tę można wyjaśnić korzystaniem z tej samej podstawy, którą nie był jednak czystopis litterae denuntiationis, ale konceptu tego pisma (minuta).

Pewien fragment prologu wskazuje natomiast na nieco bardziej skomplikowaną historię powstawania obu kopii. Autor krakowskiej denuncjacji, zanim jeszcze przeszedł do omawiania zarzutów przeciwko dominikaninowi, postanowił naszkicować idealny wizerunek kaznodziei. Fragment ten wypada różnie w obu kopiach. K1: Presupponitur quod predicator fidei catholice debet esse uelud aurum ignitum probatum et eloquium castum igne distrectionis examinatum, que satis patent. K2: Presupponitur quod predicatoris euuangelici uerbum debet esse uelud aurum ignitum probatum et eloquium castum igne distrectionis examinatum, hoc satis patet. Przy pobieżnej lekturze wersja rękopisu Kr1 wydaje się poprawna lub co najmniej dopuszczalna, tym bardziej że w dalszej części autor kontynuował swoje refleksje na temat kaznodziei: Item predicator debet esse minister pacis. W istocie jednak logiczna i zgodna z całością wywodu jest tylko wersja przekazana przez rękopis Kr2. Seria biblijnych porównań (aurum - - probatum et eloquium castum - - examinatum) odnosiła się nie do osoby samego kaznodziei, jak podaje Kr1, ale do wypowiadanego przez niego słowa (predicatoris euuangelici uerbum). Ponadto autor denuncjacji konsekwentnie używał w swoim tekście określenia os euuangelici predicatoris (art. 3) oraz in predicationis officio euuangelico (art. 2). Pojawienie się zatem w Kr1 słów predicator fidei catholice należy potraktować jako niefortunną interwencję samego kopisty ${ }^{12}$.

Po denuncjacji każdy z naszych kopistów dołączył tekst z odpowiedziami dominikanina. Rozbieżności pomiędzy tym fragmentem źródła w rękopisach Kr1 i Kr2 są wyraźne, a ich wzajemnych podobieństw możemy poszukiwać jedynie na poziomie wspólnej tematyki, nie zaś struktury, warstwy językowej, tonacji i stylu oraz użytych przez dominikanina autorytetów. Niewątpliwie mamy do czynienia z dwoma różnymi tekstami. Każdy z nich - o czym więcej napiszę przy okazji omawiania procedury denuncjacyjnej - jest świadectwem innego etapu postępowania sądowego.

W rękopisie Kr1 zachowała się lista sześciu konkluzji (conclusiones), które frater Nicolaus publice coram populo proponet. Kopista zapewne przepisal tekst ogłoszony publicznie przez dominikanina, czego świadectwem jest trzecia konkluzja, w której pozwany przemówił w pierwszej osobie: Ego tamen in hoc excessiue dixi, quod hereticos et hussonistas appelaui. Niemniej jednak kopista dokonał redakcji

${ }_{12}$ Biorąc pod uwagę, że rękopis Kr1 powstał w czasie gorących debat doktrynalnych z hustytami, zamiana „kanodziei ewanglicznego” na „kaznodzieję wiary katolickiej” specjalnie nie zaskakuje. Okazuje się zatem, że pisarz w imię źle rozumianej troski o dobro Kościoła był gotowy zmienić, a de facto zepsuć, przepisywany tekst. 
tekstu, jak sam bowiem zaznaczył: Quartam conclusionem obmitto. Być może od niego pochodzą również określenia wypowiedzi dominikanina jako conclusiones $^{13}$. Chociaż dominikanin przedstawił konkluzje jako swoje oficjalne stanowisko wobec postawionych mu zarzutów, to najprawdopodobniej - co postaram się wykazać w rozważaniach o osobie brata Mikołaja - nie był on ich bezpośrednim autorem. Autor konkluzji na pewno skorzystał z listy zarzutów oraz opinii prawno-teologicznych zamieszczonych w denuncjacji:

\begin{tabular}{|c|c|}
\hline Litterae denuntiationis & Conclusiones \\
\hline $\begin{array}{l}\text { art. 6: Finis autem istius articuli criminatur } \\
\text { uniuersitatem plabanorum, in qua possunt } \\
\text { boni esse et mali. }\end{array}$ & $\begin{array}{l}\text { con. 2: multitudinem absolute terminat, in qua } \\
\text { sunt boni et mali. }\end{array}$ \\
\hline $\begin{array}{l}\text { art. 9: Verum corpus Domini nostri Ihesu } \\
\text { Christi in ueritate manibus sacerdotum tractari } \\
\text { et frangi et fidelium dentibus atteri, quia illa } \\
\text { attricio et fractio debet referri ad species, non } \\
\text { ad uerum corpus Christi-- Ex quo patet quod } \\
\text { licet factum per partes diuiditur sub illo tamen } \\
\text { integrum corpus Christi latet glorificatum } \\
\text { enim corpus non recipit aliquam lesionem. }\end{array}$ & $\begin{array}{l}\text { con. 7: Circa materiam sacramenti sit ista } \\
\text { conclusio. Licet factum per partes diuiditur } \\
\text { sub illo tamen corpus Christi latet glorificatum } \\
\text { enim corpus non recipit aliquam lesionem. } \\
\text { Attricio et fractio fit in specibus non in corpore } \\
\text { Christi et quam diu durantur species, tam diu } \\
\text { est ibi uerum corpus Christi. }\end{array}$ \\
\hline
\end{tabular}

Analizą treści conclusiones zajmę się niżej, natomiast już teraz zwrócę uwagę na jedną obserwację, niezwykle istotną z perspektywy ustalenia datacji omawianego źródła. W pięciu na sześć konkluzji został przytoczony prawie w całości rozdział 20 z krakowskich statutów synodalnych biskupa Wojciecha Jastrzębca z 1420 r. ${ }^{14}$ Data dzienna zwołania i sporządzenia tekstu statutów nie jest nam znana, choć istnieją przesłanki wskazujące na koniec roku ${ }^{15}$. Obecność uchwał synodalnych w konkluzjach dominikanina rodzi uzasadnione przypuszczenia, że genezy dominikańskich odpowiedzi należy poszukiwać najwcześniej na początku $1421 \mathrm{r}$. Datacja ta jest wysoce prawdopodobna, tym bardziej że doskonale koresponduje z wynikami badań kodykologicznych nad rękopisem $\mathrm{Kr1}$.

Kopista Kr2 do swojej denuncjacji również dołączył drugi tekst przygotowany przez dominikanina, ale nie w formie sześciu conclusiones, lecz dziewięciu odpowiedzi

13 Conclusio było terminem technicznym z dydaktyki uniwersyteckiej i oznaczało tezę ostatecznie zamykającą scholastyczną kwestię lub jej część sformułowana pozytywnie - B. Ch mi elow s k a, „Ars praedicandi” Stanisława ze Skarbimierza, w: Retoryka w XV wieku, Wrocław 1988, s. 124; M. Te e u w e n, The Vocabulary of Intellectual Life in the Middle Ages, Turnhout 2003, s. 343-344.

14 Statuta Alberti Jastrzębiec episcopi Cracoviensis, wyd. U. Heyzmann, Starodawne prawa polskiego pomniki, t. IV, Kraków 1875, s. 84-85.

${ }^{15}$ Warto zauważyć, że w edycji U. Heyzmann statuty są błędnie datowane na 1423 r. Zob. J. S a w i c k i, Concilia Poloniae. Źródła i studia krytyczne, [t. IV:] Najdawniejsze statuty synodalne diecezji chełmskiej z XV w., Lublin 1948, s. 68-72; L. Z y g n e r, Działalność synodalna arcybiskupa Wojciecha Jastrzębca (próba retrospekcji i reinterpretacji), Studia Mazowieckie 10/24, 2015, z. 3, s. 61-62; K. O ż ó g, Biskupa Wojciecha Jastrzębca „paterna sollicitudo” o Kościół krakowski. Statuty synodalne z roku 1420, w: Wojciech Jastrzębiec - dyplomata i arcybiskup, Katowice 2017 (w druku). Serdecznie dziękuję Panu Prof. Krzysztofowi Ożogowi za udostępnienie mi tego tekstu. 
na wszystkie zarzuty wymienione w denuncjacji (positiones et responsiones). Pisarz scalił oba pisma $\mathrm{w}$ taki sposób, by czytelnik w trakcie lektury płynnie przechodził z list zarzutów do odpowiedzi dominikanina. Z tego też powodu prawdopodobnie świadomie opuścił petycję, czyli ostatnią część denuncjacji. Dominikanin w trakcie przygotowania swoich odpowiedzi z pewnością miał do dyspozycji wykaz zarzutów przedstawiony w liście denuncjacyjnym, np.:

\begin{tabular}{|l|l|}
\hline \multicolumn{1}{|c|}{ Litterae denuntiationis } & \multicolumn{1}{|c|}{ Positiones et responsiones } \\
\hline $\begin{array}{l}\text { art. 1: Hiis premissis declaretur primus } \\
\text { articulus, qui dicit, quod magis licet audire } \\
\text { confessiones fratribus predicatoribus seu } \\
\text { monachis quam plebanis }\end{array}$ & $\begin{array}{l}\text { Ad primum articulum dixi, quod licet audire } \\
\text { magis confessionem fratribus predicatorum } \\
\text { quam plebanis extensiue }\end{array}$ \\
\hline $\begin{array}{l}\text { art. 3: Tertius articulus qui continet in effectum, } \\
\text { quod qui passim fratribus predicatoribus } \\
\text { inhibent, sunt heretici et hussoniste }\end{array}$ & $\begin{array}{l}\text { Ad tertium qui confiteri fratribus predicatori- } \\
\text { bus inhibent, sunt heretici et huszsite }\end{array}$ \\
\hline
\end{tabular}

W odróżnieniu od tekstu z Kr1, w wersji z Kr2 dominikanin w swoich odpowiedziach sięgnął zaledwie po kilka auctoritates i raczej starał się własnymi słowami wyłożyć to, co tak naprawdę myśli o zarzutach z denuncjacji i osobach, które doniosły na niego do biskupa. Biorąc pod uwagę zarówno żywy styl, jak i oryginalność argumentacji, nie dziwi, że kopista Kr2 zainteresował się tym właśnie tekstem zamiast oficjalną i bardzo stonowaną listą konkluzji z Kr1.

Podsumowując, krytyka tekstu pozwala stwierdzić, że rękopisy Kr1 i Kr2 zawierają trzy różne teksty: denuncjację, odpowiedzi dominikanina na zarzuty oraz przedstawione przez niego konkluzje. W przypadku denuntiatio kopiści obu rękopisów korzystali z jednego pierwowzoru $(\alpha)$, którym był, jak przypuszczam, koncept przekazanego biskupowi listu denuncjacyjnego $(\Omega)$. Wierniej oddała go kopia Kr2. Kopista ten połączył tekst denuncjacji z dziewięcioma positiones et responsiones oskarżonego (ß). Natomiast kopista Kr1 do denucjacji dodał tekst ogłoszonych przez oskarżonego conclusiones $(\gamma)$. Oskarżony dominikanin w trakcie sporządzania ß oraz autor $\gamma$ najprawdopodobniej korzystali z oryginalnego listu denuncajcyjnego $(\Omega)$ lub jego fragmentu, zawierającego listę zarzutów wraz z opinią prawno-teologiczną. Schemat filiacji rękopisów przedstawia się następująco:

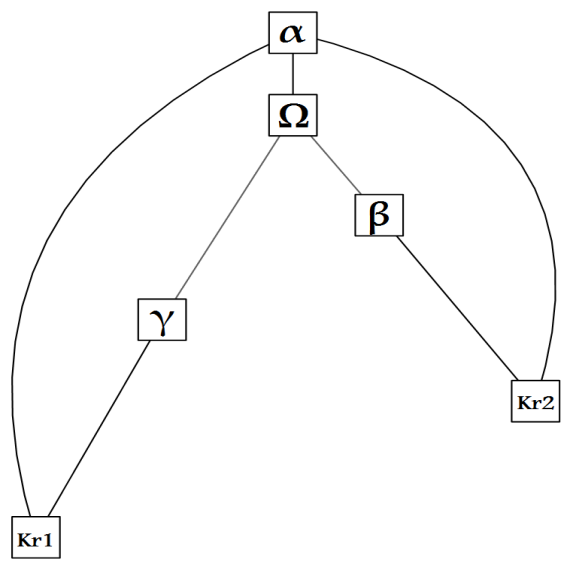




\section{DENUNCJACJA W PRAWIE KANONICZNYM}

Autor denuncjacji już w pierwszym zdaniu krótko i konkretnie przedstawił przedmiot oraz cel sporządzenia pisma: Reuerendissime Pater, in denuntiationis materia ad ostendendum, quod articuli per me uia denuntiationis oblati quidam sunt iuri contrarii, quidam scandalosi, quidam piarum animarum offensiui, quidam de fide suspecti. W ostatnim zdaniu z kolei raz jeszcze zwrócił się wprost do adresata z prośbą o adekwatną reakcję: Hoc produco non faciendo me accusatorem, sed uestre paternitatis officium ad quod pertinet errores corrigere implorando. Użycie w salutacji epitetu retorycznego w stopniu najwyższym oraz dwukrotne podkreślenie „ojcowskiego" charakter urzędu piastowanego przez adresata wskazuje, że autor skierował swoje pismo do biskupa ${ }^{16}$. W ostatnim zdaniu znajdujemy jeszcze jedną, istotną dla nas informację - autor mianowicie wyraźnie zaznaczył, że on sam, choć sporządził niniejsze pismo, to jednak nie występuje jako formalny oskarżyciel (accusator). Ewidentnie zatem nie chodziło mu o wszczęcie procedury karnej w trybie skargowym. Ponieważ autor zaznaczył, że pismo ma na celu zadenuncjowanie dominikanina i zostało przygotowane na podstawie zarzutów zebranych na drodze denuncjacji, a co więcej, zwrócił się z interwencją do biskupa, możemy przypuszczać, że mamy do czynienia z trzecią, obok skargowej i inkwizycyjnej, procedurą sądową przed sądem kościelnym, mianowicie postępowaniem denuncjacyjnym ${ }^{17}$. Aby zatem zrozumieć motywy, jakimi kierował się autor, wybierając ten sposób dochodzenia sprawiedliwości, warto pokrótce przyjrzeć się problemowi denuncjacji w średniowiecznym prawie kościelnym.

Procedura denuncjacyjna ma swoje źródło przede wszystkim w ewangelicznym nakazie upomnienia braterskiego (correctio fraterna). Według słów Chrystusa: „Gdy brat twój zgrzeszy, idź i upomnij go w cztery oczy - - . Jeśli zaś nie usłucha, weź z sobą jeszcze jednego albo dwóch, żeby na słowie dwóch albo trzech świadków oparła się cała sprawa. Jeśli i tych nie usłucha, donieś Kościołowi!” (Mt 18, 15-17). W doktrynie Kościoła correctio fraterna była interpretowana jako wyraz konkretnej miłości i sprawiedliwości wobec bliźniego. Tomasz z Akwinu poświęcił temu zagadnieniu osobną kwestię w swojej Summie teologii ${ }^{18}$, w której wyjaśnił, że napomnienie braterskie jako obowiązek nakazany przez przykazanie jest dwojakiego rodzaju. Pierwsze, rozumiane jako akt miłości, zmierza do poprawy grzesznika (correctio, quae est actus caritatis). Do tego rodzaju napomnienia wezwani są wszyscy chrześcijanie

${ }^{16}$ S. K u r a ś, Przywileje prawa niemieckiego miast i wsi malopolskich XIV-XV wieku, Wrocław 1971, s. 11-12.

${ }^{17}$ A. E s m e i n, A History of Continental Criminal Procedure: With Special Reference to France, thum. J. Simpson, Boston 1913, s. 85-87; P. B e 11 i n i, „Denunciatio evangelica” e „denunciatio iudicialis privata". Un capitulo di storia disciplinare della Chiesa, Milano 1986; C. L e f e b v r e, Gratien et les origines de la dénonciation évangélique, De l'accusatio à la denunciatio, Studia Gratiana 4, 1956/57, s. 231-250; W. D e c o c k, Theologians and Contract Law: The Moral Transformation of the „Ius Commune” (ca. 1500-1650), Leiden-Boston 2013, s. 88-101.

18 Thomas de Aquino, Summa theologiae, Pars II $^{\mathrm{a}}-\mathrm{II}^{\mathrm{ae}}$, q. 33, a. 1-8 (ed. Commissio Leonina, t. VIII, Romae 1895, s. 262-272); tenże, Super Evangelium Matthaei lectura, c. XVIII, lect. 2 (ed. Typographia Pontificia Petri Marietti, Taurini-Romae 1951, s. 231-233, nr 1514-1523). 
bez względu na stan i sprawowane funkcje ${ }^{19}$. Drugi typ napomnienia (correctio, quae est actus iustitiae) wynika nie tylko z miłości wobec grzesznika, ale również $\mathrm{z}$ chęci przywrócenia porządku we wspólnocie oraz naprawy krzywd wyrządzonych przez czyny grzesznika. Ten rodzaj, będący aktem sprawiedliwości, mogli stosować tylko przełożeni wobec swoich podwładnych ${ }^{20}$. W obu przypadkach napomnienie powinno odbyć się w porządku podanym przez Ewangelię, czyli najpierw w cztery oczy (secreta admonitio), a następnie w obecności kilku świadków. Dopiero gdyby te wysiłki okazały się nieskuteczne, należało odwołać się do denuncjacji. Gdyby zaś $i$ ta nie przyniosła poprawy grzesznika, Tomasz zalecał pozostawienie sprawy osądowi samego Boga. Co ważne, Akwinata właściwą materią correctionis fraternae uczynił przede wszystkim przewinienia ukryte (peccata occulta). W przypadku zaś zdrady i spisków przeciwko legalnej władzy, herezji, grzechów publicznych i poważnych przestępstw należało odwołać się od razu do denuncjacji publicznej (denuntiatio publica ${ }^{21}$. Warto jeszcze dodać, że Tomasz precyzyjnie odróżniał denuncjację od skargi oskarżycielskiej (accusatio). Denuncjacja służyła poprawie winowajcy (emendatio fratris), a skarga - wymierzeniu kary (punitio criminis). Denuncjator mógł liczyć co najwyżej na duchową satysfakcję z powodu nawrócenia grzesznika, oskarżyciel zaś - na materialne zadośćuczynienie. Właściwym miejscem składania denuncjacji była wspólnota wiernych, skargi natomiast - sąd. Istotne było również, by osoba składająca denuncjację kierowała się wyłącznie prawymi pobudkami, tj. dobrą gorliwością (bonus zelus) i bezinteresowną troską o zbawienie bliźniego ${ }^{22}$. Owa bezinteresowność była warunkiem sine qua non i kolejną cechą, która odróżniała denuncjację od oskarżenia. Generalnie dla Tomasza z Akwinu, podobnie jak i innych średniowiecznych teologów, correctio fraterna, w tym również denuntiatio, była elementem stałej duchowej formacji chrześcijańskiej.

Problemem upomnienia braterskiego i samej denuncjacji zainteresowani byli również ówczesni prawnicy. Gracjan, przygotowując ok. 1140 r. swój Dekret, wspomina kilkukrotnie o denuncjacji (denuntiatio, indicatio, delatio, correctio) ${ }^{23}$. Trzeba jednak zauważyć, że była ona traktowana wyłącznie jako jeden z etapów postępowania skargowego i nie miała jeszcze charakteru osobnej procedury ${ }^{24}$. Momentem przełomowym w „prawniczej egzegezie” cytowanego ustępu Mt 18, 15-17 było ogłoszenie w 1205 r. przez papieża Innocentego III w sławnej bulli Novit ille, włączonej, co ważne, również do korpusu prawa kanonicznego ${ }^{25}$. Innocenty, odpowiadając na prośbę króla angielskiego Jana bez Ziemi o pomoc w zakończeniu konfliktu z królem Francji Filipem II Augustem, wyjaśnił, że co prawda nie może

19 Summa theologiae, art. 1 (s. 262-263).

20 Tamże, art. 3 (s. 265).

${ }^{21}$ Tamże, art. 7 (s. 269-271).

${ }^{22}$ Tamże, q. 68, art. 1, resp. (ed. Commissio Leonina, t. IX, Romae 1897, s. 104).

${ }^{23}$ Zwłaszcza: Decretum Gratiani, P. II, C. II, q. 1, c. 19 (wyd. E. Friedberg, t. I, Leipzig 1879, kol. 447); c. 21 (kol. 449); q. 7, c. 47 (kol. 499); C. V, q. 5, c. 1 (kol. 549); c. 5 (kol. 550-551); C. XXIII, q. 4, c. 5 (kol. 900); C. XXIV, q. 3, c. 14 (kol. 994).

${ }^{24}$ C. Le fe bvre, Gratien, s. 234-238.

${ }_{25}$ Decretales Gregorii IX, lib. II, tit. I, c. 13 (wyd. E. Friedberg, t. II, Leipzig 1879, kol. 242-244); zob. W. D e c o c k, Theologians, s. 91-92. 
on rostrzygać spraw związanych z prawem feudalnym, ale jako papież może interweniować w sprawy świeckie w momencie zaistnienia grzechu (ratione peccati). W takiej sytuacji działanie papieża miałoby być dosłownym wypełnieniem nakazu Chrystusa: „Jeśli i tych nie usłucha, donieś Kościołowi!” (Mt 18, 17)26. Kanon Novit ille otworzył drogę nowej interpretacji ewangelicznej denuntiatio, która od tej pory mogła być motywowana nie tylko troską o zbawienie bliźniego, lecz także troską o sprawy doczesne poszkodowanego. To przekierunkowanie lub raczej rozszerzenie zakresu denuncjacji z „,bezinteresownej” na ,interesowną” zyskało wkrótce dodatkowe wsparcie ze strony kanonisty Sinibalda Fieschi (przyszłego papieża Innocentego IV). W swoim komentarzu do dokumentu Innocentego III stwierdził on, że poszkodowany ma prawo donieść na swojego dłużnika, który dopóki nie zwróci długu, może być pozbawiony rozgrzeszenia ${ }^{27}$. W ten sposób denuntiatio przestała być wyłącznie ostatnim etapem correctionis fraternae lub też elementem postępowania skargowego, ale stała się osobną procedurą w prawie kościelnym.

Jednym z pierwszych uczonych, który postanowił uporządkować całą dotychczasową dyskusję na temat denuncjacji, był kardynał Ostii, kanonista i autor najbardziej popularnego w średniowiecznej Europie wykładu prawa kanonicznego - Henryk z Suzy (de Segusio) ${ }^{28}$. Opracował on gruntownie temat procesu denuncjacyjnego w Summa super titulis Decretalium (tzw. Summa aurea) ${ }^{29}$ oraz w komentarzu do wspomnianego już kanonu Novit ille ${ }^{30}$ i dekretu Innocentego IV Romana ecclesia ${ }^{31}$. W pierwszej kolejności Henryk zaproponował następującą definicję denuncjacji: Criminis alicuius apud iudicem sine inscriptione legitime facta delatio: ad poenitentiam peragendam, vel aliam poenam legitimam imponendam, vel etiam ad utrumque ${ }^{32}$. Według Henryka zatem głównym celem denuncjacji była poprawa grzesznika albo przez nałożenie pokuty (poenitentia) lub sankcji karnej (poena), albo też zastosowanie obu tych środków. Denuncjator, inaczej niż oskarżyciel w postępowaniu skargowym, nie był zobowiązany do złożenia inscriptio legitima, czyli formalnej

${ }^{26}$ Decretales Gregorii IX, lib. II, tit. I, c. 13 (kol. 243): Sed, cum Dominus dicat in Evangelio: Si peccaverit in te frater tuus, vade et cor eum inter te et ipsum solum: si te audierit, lucratus eris fratrem tuum; si te autem non audierit, adhibe tecum adhuc unum vel duos, ut in ore duorum vel trium testium stet omne verbum; quod si non audierit eos, dic ecclesiae; si autem ecclesiam non audierit, sit tibi sicut ethnicus et publicanus. Et rex Angliae, sicut asserit, sit paratus sufficienter ostendere, quod rex Francorum peccat in eum, et ipse circa illum in correctione processit secundum regulam evangelicam, et tandem, quia nullo modo profecit, dicat Ecclesiae, quomodo, nos, qui sumus ad regimen universalis Ecclesiae superna dispositione vocati, mandatum divinum possumus exaudire, ut non procedamus secundum formam ipsius, nisi forsan ipse coram nobis vel delegato nostro sufficientem in contrarium rationem ostendat?

${ }^{27}$ W. D e c o c k, Theologians, s. 92.

${ }^{28}$ K. P e n n ingto n, Enrico da Susa, detto l'Ostiense, w: Dizionario biografico degli Italiani, t. XLII, Roma 1993, s. 758-763.

${ }^{29}$ Henricus de Segusio, Summa aurea, Coloniae 1612, kol. 1303-1308.

${ }^{30}$ Tenże, In secundum Decretalium librum commentaria, Venetiis 1581, k. 5v-6r, nr 10-13.

${ }^{31}$ Liber sextus decretalium, lib. III, tit. 20, c. 1 (wyd. E. Friedberg, t. II, Leipzig 1879, kol. 1056-1057); Henricus de Segusio, In sextum Decretalium librum commentaria, Venetiis 1581, k. 26v-27r, nr 28-38.

${ }^{32}$ Henricus de Segusio, Summa, kol. 1303, nr 1. 
skargi ${ }^{33}$. Jednakże w razie złożenia fałszywego doniesienia sam był obciążany odpowiednią karą, a w przypadku osób duchownych nawet wydaleniem ze stanu kapłańskiego ${ }^{34}$.

Henryk z Suzy wyróżnił i opisał kilka rodzajów denuncjacji. Pierwszym była denuncjacja ewangeliczna (denuntiatio evangelica, penitencialis), której głównym celem było nawrócenie grzesznika, a materią były tylko grzechy ukryte, lecz - jak zauważa autor - „nie na tyle, by nie można ich było wykazać”; sędzią w tego rodzaju przypadkach miał być odpowiedni przełożony (praelatus) ${ }^{35}$. W przypadku gdy denuncjacja ewangeliczna okazywała się nieskuteczna, a grzech winowajcy był powszechnie znany (peccata manifesta), można było odwołać się do denuncjacji sądowej publicznej (denuntiatio iudicalis publica) ${ }^{36}$. Taka procedura była wszczynana ex officio przez biskupa lub - gdyby ten odmówił przeprowadzenia postępowania - przez arcybiskupa. Henryk wyraźnie zaznaczył, że biskup był zobowiązany do zajęcia się tego typu sprawami, gdyż ad eius curam hoc pertinet ${ }^{37}$. Dzięki denuncjacji sądowej publicznej winowajca miał zmienić nie tylko swoje postępowanie, ale także zadośćuczynić za popełnione zło. Osobny rodzaj stanowiła denuncjacja sądowa prywatna (denuntiatio iudicalis privata), która wszczynana był po złożeniu przez poszkodowanego denuncjacji, gdy aliquis mihi iniurietur, vel rem meam aufe$r^{3} t^{38}$. Warto $\mathrm{w}$ tym miejscu zauważyć pewną subtelną, ale istotną różnicę pomiędzy denucjacją sądową publiczną a prywatną. Mianowicie publiczna była wszczynana $\mathrm{z}$ powodu zaistniałego grzechu (ratione peccati), prywatna zaś w pierwszej kolejności w celu obrony konkretnych dóbr poszkodowanego (ratione interesse). Publicznej było bliżej do ewangelicznego upomnienia braterskiego, a prywatnej do postępowania skargowego. Denuncjacja sądowa prywatna miała pomóc - jak wyjaśniał Henryk - przede wszystkim „biednym i uciśnionym” (denuntiantes pauperes et opressi), którzy z różnych powodów mieliby problem ze złożeniem formalnej skargi, przede wszystkim z powodu stosunku zależności względem winowajcy ${ }^{39}$. Henryk z Suzy po obszernym przedstawieniu denuncjacji ewangelicznej i sądowej opisał jeszcze trzeci typ denuncjacji: kanoniczna specjalna i generalna. Wspomnijmy krótko, że denuntiatio canonica specialis stosowana była wobec duchownych w celu pozbawienia kogoś beneficjum, natomiast denuntiatio canonica generalis - wobec decyzji sędziów kościelnych ${ }^{40}$. W opinii Henryka z powyższych trzech procedur mogli skorzystać wszyscy wierni z wyjątkiem zakonników. Trafnie bowiem zauważył, że jeżeli chcieliby oni zadenuncjować swojego przełożonego, powinni odwołać się do przewidzianych przez ich prawo zakonne odpowiednich instytucji,

${ }^{33}$ Decretales Gregorii IX, lib. V, tit. 1, c. 17 (kol. 738-739); tit. 3, c. 31 (kol. 760-761); zob. K. A m i e la ń c z y k, Zasada skargowości i zakaz orzekania ponad żądanie stron w procesie rzymskim, Gdańskie Studia Prawnicze 33, 2015, s. 41-43.

${ }^{34}$ Henricus de Segusio, Summa, kol. 1306, 1308.

35 Tamże, kol. 1304; tenże, In secundum, k. 5v, nr 10; tenże, In sextum, k. 26v, nr 29.

36 Tenże, Summa, kol. 1306; tenże, In secundum, k. 5v-6r, nr 10-11; tenże, In sextum, k. 26v-27r, nr 31.

37 Tenże, In sextum, k. 26v, nr 31.

38 Tenże, Summa, kol. 1304-1305; tenże, In sextum, k. 26v-27r, nr 32-33.

39 Tenże, In sextum, k. 26v, nr 32.

40 Tamże, k. 27r, nr 35-36. 
regulujących tego rodzaju konfliktowe sytuacje, np. kapituł win, kapituł prowincjalnych i generalnych ${ }^{41}$.

Jeżeli chodzi o modus procedendi w postępowaniu denuncjacyjnym, Henryk w swojej Summie przedstawił bardzo ogólnie dwa modele. Pierwszy, przewidziany przy denuntiatio evangelica, należało zastosować, gdy jedynym oczekiwanym skutkiem miała być poprawa winowajcy w wyniku nałożenia pokuty (ad correcrtionem peccati $)^{42}$. Sędzia, w tym przypadku jakikolwiek przełożony, po otrzymaniu denuncjacji odbierał zarówno od denuncjatora, jak i winowajcy stosowną przysięgę (iuramentum). Gdy ten ostatni przyznawał się do winy lub gdy przedstawiono dowód pełny (probatio plena), np. zeznania wiarygodnych świadków potwierdzających zarzuty, wówczas otrzymywał stosowną pokutę. W sytuacji gdy doniesienie okazywało się nieprawdziwe, oskarżony był oczyszczany z zarzutów, a denuncjator ponosił odpowiednią karę. W przypadku denuntationis iudicialis i canonicae czynności sądowe były generalnie zbieżne z klasycznym przewodem kanonicznym ${ }^{43}$. Strony w postępowaniu denuncjacyjnym nie musiały występować w sądzie samodzielnie, ale mogli je reprezentować zawodowi adwokaci zwani prokuratorami ${ }^{44}$. Denuncjacja w formie listu denuncjacyjnego (literrae denuntiationis) była adresowana do biskupa lub arcybiskupa, który mógł daną sprawę zastrzec dla siebie albo przekazać ją swojemu oficjałowi, który sprawował władzę sądowniczą zwyczajną (iudex ordinarius), lub innemu sędziemu (iudex delegatus). Pozew denuncjacyjny - jak wyjaśnił Henryk miała formę libellus denuntiationis, przy czym nie określił formalnych wymogów dla tego typu dokumentów ${ }^{45}$. Najprawdopodobniej pozew taki był podobny do pozwu w sprawach karnych (libellus accusationis), czyli przedstawiał przedmiot oraz wyszczególniał wszystkie motywy, na podstawie których wniesiono denuncjację ${ }^{46}$. Sędzia zobowiązany był dostarczyć pozew winowajcy i wyznaczał datę pierwszej rozprawy. Po tych czynnościach następowało zawiązanie sporu (litis contestatio) oraz złożenie przez powoda i pozwanego przysięgi (iuramentum de veritate dicenda). Osoba pozwana miała prawo podważyć wiarygodność denuncjatora, wykazując, że ten jest inimicus, vel excomunicatus, vel quia non monuit ipsum, vel quia dicit denuntiationem non debere procedere ex eo ${ }^{47}$. Jeżeli jednak oskarżony nie zgłaszał żadnych zarzutów formalnych co do osoby powoda lub sędziego, to następowały kolejne etapy przewodu sądowego. Osoba składająca doniesienie przedkładała tzw. pozycje (positiones), tj. pisemny raport przedstawiający zarzuty i uzasadniający złożenie denuncjacji. Strona przeciwna prosiła sędziego o odpis i przygotowywała

${ }^{41}$ Tamże, k. 27r, nr 37; o kapitułach win oraz sądach w trakcie kapituł prowincjalnych zob. T. G a ł u s z k a, Kara więzienia w późnośredniowiecznej polityce penitencjarnej dominikanów polskich, Kwartalnik Historyczny 117, 2010, nr 4, s. 65-79; t e n ż e, Mikołaja Duthorowa OP „Error condemnatus ab Ecclesia”. Dominikanie polscy wobec herezji i nowych nurtów pobożności w 1. połowie XIV wieku, tamże 122, 2014, nr 1, s. 73-106.

${ }^{42}$ Henricus de Segusio, Summa, kol. 1307.

43 Tamże, kol. 1307-1308; o procesie kanonicznym zob. E. K n a p e k, Akta oficjalatu i wikariatu generalnego krakowskiego do połowy XVI wieku, Kraków 2010, s. 76-88.

${ }^{44}$ A. E s m e i n, A History, s. 87; E. K n a p e k, Akta oficjalatu, s. 77.

${ }^{45}$ Zob. Henricus de Segusio, Summa, kol. 1307.

${ }^{46}$ Zob. E. Kn a pe k, Akta oficjalatu, s. 78, 80.

${ }^{47}$ Henricus de Segusio, Summa, kol. 1307. 
własną odpowiedź (positiones et responsiones contra articulos). Henryk wspomniał jeszcze o innych typowych dla procesu kanonicznego elementach przewodu sądowego, jak przedstawienie materiału dowodowego (probationes), zgłoszenie przez powoda świadków (testes quos denuntians nominaverit), wnoszenie ekscepcji przeciw denuncjacji oraz wiarygodności zeznań świadków (exceptiones). Proces kończył się wyrokiem przeciwko pozwanemu (sententia contra denuntiatum), tj. wyznaczeniem odpowiedniej pokuty oraz nałożeniem kary kościelnej ${ }^{48}$. Warto dodać, że w opinii Henryka „doskonała pokuta” (perfecta poenitentia) musiała uwzględniać restytucję dóbr utraconych przez poszkodowanego.

Opisana powyżej procedura denuncjacyjna jest podobna do postępowania inkwizycyjnego, w którym kluczową rolę również pełniły denuncjacja i działanie sędziego ex mero officio ${ }^{49}$. Tym jednak, co odróżniało oba postępowania, było przede wszystkim większe zaangażowanie osoby zgłaszającej denuncjację. W postępowaniu per denuntiationem głównym zainteresowanym wszczęciem postępowania był nie tyle sam sędzia (jak w procesach per inquisitionem), ile denuncjator. On też był zobowiązany ,przekonać” sędziego, by ten rozpoczął postępowanie z urzędu, czyli na sposób inkwizycyjny. Inaczej niż w postępowaniu inkwizycyjnym, osoba składająca doniesienie musiała nie tylko cieszyć się dobrą sławą, ale również potwierdzić zasadność denuncjacji odpowiednimi dowodami ${ }^{50}$. Ponadto procedura denuncjacyjna była wszczynana dopiero wówczas, gdy denuncjacja ewangeliczna lub inne formy correctionis fraternae okazywały się nieskuteczne.

Przedstawione wyżej refleksje na temat denuncjacji i postępowania denuncjacyjnego w prawie kościelnym stanowią odpowiedni punkt wyjścia interpretacji omawianego tekstu z rękopisów Kr1 i Kr2 oraz rekonstrukcji sprawy brata Mikołaja. Możemy przypuszczać, że oba rękopisy zawierają część akt z postępowania denuncjacyjnego, a dokładniej: procedury denuntiatio iudicalis publica. Krakowska denuncjacja została sporządzona przez autora, który wyraźnie podkreślił, że nie jest oskarżycielem. Możemy jednak przypuszczać, że pełnił on funkcję prokuratora anonimowych poszkodowanych. Ci poszkodowani to grupa lokalnych duchownych (sacerdotes et plebani). Jak przyznał sam pozwany, duchowni ci podejmowali - zgodnie z procedurą correctionis fraternae - już wcześniej próby formalnego upomnienia go za pomocą zawiadomienia (intimitatio). Jednakże złożone przez niego wyjaśnienia okazały się na tyle niesatysfakcjonujące $\mathrm{z}$ punktu widzenia poszkodowanych, że postanowili oni zaangażować prawnego reprezentanta. On też na podstawie ich zeznań przygotował obszerny list denuncjacyjny (litterae denuntiationis), w którym zawarł zarówno listę zarzutów stawianych dominikaninowi, jak i własną opinię prawno-

48 Tamże, kol. 1308.

$49 \mathrm{P}$. K r a s, „Ad abolendam diversarum haeresium pravitatem”. System inkwizycyjny w średniowiecznej Europie, Lublin 2006, zwłaszcza s. 187-256 (tu obszerna literatura).

${ }^{50}$ A. E s m e i n, A History, s. 86. To m.in. z tych właśnie powodów inny autor popularnego w XV w. komentarza do prawa kanonicznego, Mikołaj de Tudeschis (zw. Panormitanus), jasno rozróżnił postępowanie denuncjacyjne i inkwizycyjne: Proprie processus inquisitionis est, quod iudex fecit ex officio suo puro et mero, nemine deferente et impetrante inquisitionem. Sed quando fit ad denuntiationem alterius, tunc est proprie processus per viam denuntiationis (Nicolaus de Tudeschis [Panormitanus], In quintum librum Decretalium commentaria, [De accusationibus], c. 25, Venetiis 1582 , k. 124v, nr 21). 
-teologiczną. Zgodnie z wymogami stawianymi procedurze denuncjacji sądowej list został skierowany wprost do biskupa, w którego kompetencji było - co przypomnieli zarówno Henryk z Suzy, jak i autor analizowanego źródła - ,poprawianie błędów”. Koncept tego listu denuncjacyjnego stał się podstawą obu kopii w rękopisach Kr1 i Kr2. Biskup pozytywnie rozpatrzył petycję adresata i wszczął postępowanie. Oczywiście procedura w krakowskim sądzie mogła odbiegać od wzorcowego opisu u Henryka z Suzy i biskup mógł ograniczyć się tylko do podstawowych elementów postępowania denuncjacyjnego. Na podstawie dostarczonej litterae denuntiationis, został sporządzony pozew denuncjacyjny (libellus denuntiationis), który następnie został on przekazany pozwanemu dominikaninowi. Zakonnik przygotował własną odpowiedź (positiones et responsiones), w której odpierał poszczególne zarzuty. Jej tekst zachował się w rękopisie Kr2. Jak pamiętamy, zakonnik odniósł się do wszystkich zarzutów, a równocześnie sam zgłosił także szereg zarzutów odnośnie do osób składających denuncjację. Jego odpowiedź przybrała wręcz formę skargi wzajemnej. Możemy przypuszczać, że w toku procesu powstała jeszcze jakaś druga, nieznana nam, odpowiedź na wyjaśnienia przedłożone przez dominikanina. Pewne jest natomiast, że dominikanin na ostatnim etapie procesu, być może podczas rozprawy zamykającej postępowanie dowodowe (conclusio in causa) ${ }^{51}$, upublicznił sześć ogólnych konkluzji (conclusiones). Ich treść znamy dzięki rękopisowi Kr1. Autor konkluzji ograniczył się przede wszystkim do dosłownego przytoczenia fragmentów z krakowskich statutów synodalnych z 1420 r. oraz - co znamienne - z opinii teologicznej samego twórcy denuncjacji (art. 6-7). Niewątpliwie dominikanin nasz, ogłaszając te konkluzje, chciał definitywnie i raczej polubownie zakończyć zaistniały spór. Nie mamy żadnych informacji o sententia contra denuntiatum.

Kilku słów komentarza wymaga jeszcze sam fakt zaistnienia omawianego tutaj procesu. Wiadomo bowiem, że dominikanie cieszyli się przywilejem egzempcji, której istotą było dokonane przez Stolicę Apostolską jako najwyższą władzę jurysdykcyjną w Kościele zwolnienie zakonników spod władzy karnej biskupa ${ }^{52}$. Bracia Zakonu Kaznodziejskiego już w dniu założenia zakonu 22 XII 1216 r. zostali poddani sub gubernatione papieża ${ }^{53}$. Pełna i bezpośrednia egzempcja chroniła zarówno autonomię dominikanów, jak i ich niezależność sądowniczą w stosunku do władzy biskupów oraz innych urzędników kościelnych. Zgodnie z prawem zakonnym oskarżony in omnibus criminibus brat podlegał jurysdykcji władz zakonu (prowincjał, kapituła prowincjalna i generalna, generał) lub samego papieża. Skierowanie pozwu przeciwko dominikaninowi do sądu biskupiego mogło się skończyć co najwyżej prośbą sędziego o interwencję przełożonych zakonnych. Dlaczego zatem krakowski biskup w ogóle przyjął denuncjację i nadał bieg sprawie brata Mikołaja? W czasie

51 E. K n a p e k, Akta oficjalatu, s. 85.

52 O egzempcji w średniowieczu zob. A. W e is s, Biskupstwa bezpośrednio zależne od Stolicy Apostolskiej w średniowiecznej Europie, Lublin 1992, s. 109-120 (tam też dalsza, obszerna literatura).

53 Bullarium Ordinis Praedicatorum, wyd. T. Ripolli, t. I, Romae 1729, s. 4; T. G a ł u s z k a, Kolektor Piotr z Auvergne i plebani versus biskup Jan Grotowic i dominikanie. Studium historyczne instrumentu notarialnego z 1333 roku ze zbiorów Archivio Secreto w Watykanie, Przegląd Historyczny 105, 2014, s. 326-327 (tam też obfita literatura). 
omawianego procesu, tj. ok. 1421 r., na stolicy biskupiej zasiadał Wojciech Jastrzębiec, który rzeczywiście mógł być osobiście zainteresowany rozwiązaniem zaistniałego konfliktu. Biskup ten bowiem znany był z sympatii do dominikanów, czemu dał wyraz choćby na synodzie krakowskim w 1420 r. W 20 rozdziale statutów synodalnych przytoczonym prawie w całości w conclusiones brata Mikołaja - zabronił podległym sobie duchownym utrudniać zakonnikom słuchania spowiedzi i przypomniał m.in., że posiadający zgodę biskupa zakonnicy mają taką samą władzę jak plebani ${ }^{54}$. Co jednak szczególnie istotne z perspektywy naszego studium, to fakt, że Jastrzębiec pełnił też funkcję ustanowionego przez papieża konserwatora praw (conservator iurium) polskich dominikanów oraz franciszkanów ${ }^{55}$. Konserwatorzy jako sędziowie delegowani mieli za zadanie przede wszystkim bronić przywilejów zakonnych, zwłaszcza związanych z posługą duszpasterską i relacjami z klerem diecezjalnym oraz generalnie reagować na wszelkie akty agresji wobec powierzonych im braci ${ }^{56}$. Jest zatem zrozumiałe, że Wojciech Jastrzębiec w momencie pojawienia się sporu pomiędzy dominikaninem i lokalnym duchowieństwem skorzystał z przysługujących mu jako biskupowi, a zarazem konserwatorowi, prerogatyw i nie tylko nie oddalił sprawy, ale przyjął skargę duchownych i pozwolił dominikaninowi na szczerą odpowiedź na postawione zarzuty. Lektura konkluzji brata Mikołaja - jak zobaczymy dalej - pozwala przypuszczać, że biskup osiągnął zamierzony cel - każda ze stron procesu mogła poczuć się usatysfakcjonowana, a równocześnie „po ojcowsku” przez niego napomniana.

\section{AUTOR LISTU DENUNCJACYJNEGO}

Krakowski dominikanin otwarcie i ostro krytykował duchownych, którzy złożyli na niego denuncjację. W stosunku zaś do twórcy denuncjacji zachował znaczące milczenie. Nie zakwestionował ani jego wiarygodności, ani kompetencji, ani też dołączonych do zarzutów opinii prawno-teologicznych. Pozwany zatem mógł znać autora denuncjacji i wiedzieć, że ewentualne próby podważenia jego autorytetu są bezcelowe. Dla autora denuncjacji brat Mikołaj również nie był anonimowym zakonnikiem. Pisał o nim z szacunkiem, ale też z nieukrywanym rozczarowaniem. Według niego bowiem dominikanin przez swoje skandaliczne wypowiedzi, nielicujące - jak

${ }^{54}$ Zob. wyżej, przyp. 14.

${ }_{55}$ G. L i c h oń c z a k - N u re k, Wojciech herbu Jastrzębiec. Arcybiskup i mąż stanu, Kraków 1996, s. 116-117.

${ }^{56}$ Liber sextus decretalium, lib. I, tit. 14, c. 1 (wyd. E. Friedberg, t. II, s. 978): Statuimus, ut conservatores, quos plerumque concedimus, a manifestis iniuriis et violentiis defendere possint quos eis committimus defendendos. Zob. A. d e B o ü a rd, Les „conservatores et judices" de la Basilique de S. Pierre de Rome, Mélanges d'Archéologie et d'Histoire de l'Ecole française de Rome 30, 1910, s. 321-372; T. G a ł u s z k a, Dominikanie i spory wokół prawa do słuchania spowiedzi. Recepcja bulli Jana XXII „Vas electionis” w diecezji wrocławskiej w 1. połowie XIV wieku, Studia Źródłoznawcze 52, 2014, s. 13. Konserwatorzy również starali się - jak widzimy choćby na przykładzie następcy Jastrzębca, biskupa Zbigniewa Oleśnickiego - czynnie uczestniczyć w rozwoju powierzonych im wspólnot, zob. J. Tu re k, Spory dominikanów polskiej prowincji z duchowieństwem diecezjalnym w okresie od XIII do XV wieku, Przegląd Tomistyczny 15, 2009, s. 408-409. 
pisał - z godnością „,ewangelicznego kaznodziei”, stał się źródłem powszechnego zgorszenia. Sam autor także poczuł się osobiście dotknięty słowami zakonnika. Stąd też przygotowany przez niego tekst równie wiele mówi o jego twórcy, co o pozwanym dominikaninie. Kim zatem był autor krakowskiego listu denuncjacyjnego?

W żadnych z dwóch rękopisów nie odnotowano imienia ani godności wystawcy denuncjacji. Pierwowzór, z którego korzystali kopiści, był, jak pamiętamy, zapewne konceptem listu denuncjacyjnego, a zatem mógł być pozbawiony tych elementów formularza. Pewne jest jednak, że autor był osobą o wszechstronnych zainteresowaniach. W denuncjacji możemy go zobaczyć w kilku rolach, m.in. prawnika, teologa, obrońcy uniwersytetu i stylisty.

Na początku denuncjacji autor zaznaczył, że jego celem jest wykazanie błędów w kazaniach dominikanina. W pierwszej kolejności zajął się ich oceną pod kątem zgodności z prawem kanonicznym. Powiedzmy już teraz, że przedstawione przez niego analizy są poprawne i przekonujące oraz dowodzą, że posiadał on wykształcenie prawnicze i biegłość w posługiwaniu się prawem. Jak pokazuje analiza źródłoznawcza tekstu denuncjacji, autor w trakcie swojej pracy sięgał przynajmniej ośmiokrotnie do tekstów kanonicznych, głównie do Dekretu Gracjana (6 razy), ale również Constitutiones Clementinae i Decretales Gregorii IX. Ponadto czterokrotnie opatrzył swoje interpretacje i wyjaśnienia stosownym autorytetem patrystycznym, sięgając do Ambrożego z Mediolanu, Hieronima, Augustyna z Hippony oraz Grzegorza Wielkiego, przy czym - co trzeba podkreślić - wszystkie cytaty zostały zaczerpnięte w rzeczywistości za pośrednictwem Dekretu Gracjana. Autor przytoczył wreszcie implicite również podstawowy komentarz do tego dzieła (Glossa ordinaria). Nie ulega wątpliwości, że zbiór prawa kanonicznego był dla niego głównym narzędziem w codziennej pracy. O wiedzy i wysokich umiejętnościach autora denuncjacji świadczy również komentarz do piątego zarzutu, w którym ocenie poddano twierdzenie dominikanina, że bracia mogą spowiadać sine omni licentia. Autor, wyjaśniając błędność tego rodzaju koncepcji - o czym napiszę więcej nieco dalej - przywołał sprawę czternastowiecznego zagorzałego przeciwnika przywilejów mendykanckich Jana de Polliaco. Tych kilka obserwacji skłania wprost do poszukiwania naszego autora wśród elity prawniczej piętnastowiecznego Krakowa.

Prawo nie było wszakże jedyną dziedziną, w której celował twórca denuncjacji. Był on również biegły w teologii, czemu dał najlepszy wyraz w prologu, a zwłaszcza w opinii na temat ostatniego zarzutu, zajmującej prawie $40 \%$ tekstu denuncjacji (art. 9). Prolog niewiele różni się od areng religijnych, jakie spotykamy w dokumentach średniowiecznych ${ }^{57}$. Autor dokładnie wyjaśnił motyw sporządzenia swojego pisma, podnosząc troskę o posługę kaznodziejską i wypowiadane słowo. W konstrukcji prologu zastosował aż osiem odniesień do Biblii, które miały ilustrować, kim powinien, a kim nie powinien być kaznodzieja oraz jak winno wyglądać głoszenie kazań. Szczególnie ciekawy jest jeden fragment prologu - wspomniany już wcześniej - pokazujący niezwykłą giętkość pióra autora w przetwarzaniu tekstów biblijnych.

${ }^{57}$ Zob. T. N o w a k ow s k i, Idea areng dokumentów książąt polskich do połowy XIII wieku, Bydgoszcz 1999, s. 27-32. 


\begin{tabular}{|l|l|}
\hline Prologus: Predicatoris eunangelici uerbum & Rev. 3, 18: Suadeo tibi emere a me aurum \\
debet esse uelud aurum ignitum probatum et & ignitum probatum ut locuples fias. \\
eloquium castum igne distrectionis examinatum, & Ps 119, 140: Igne probatum est eloquium tuum \\
& valde: servus autem ruus dilexit illud. \\
& Ps 12, 7: Eloquia Domini eloquia casta, \\
argentum igne examinatum, separatum a terra, \\
purgatum septuplum.
\end{tabular}

Możemy się domyślać, że autor stworzył ten tekst, nie tyle korzystając bezpośrednio z Biblii lub innych narzędzi egzegetycznych, ile opierając się na własnej pamięci i zdolnościach stylistycznych. Dodajmy jeszcze, że w komentarzu do szóstego i ósmego zarzutu jako autorytetów nie użył on zbioru prawa, ale wyłącznie Pisma. Natomiast jako teolog w pełni ujawnił się w ostatniej i zarazem najobszerniejszej części denuncjacji. Był wyraźnie zbulwersowany doniesieniem, że dominikanin nazywał Eucharystię zwykłym jedzeniem. Postanowił zatem przypomnieć nauczanie Kościoła i trzonem swojego wykładu uczynił obszerny fragment z trzynastowiecznego komentarza franciszkańskiego teologa Ryszarda z Middletown (Mediavilla, zm. 1308) do Sentencji Piotra Lombarda ${ }^{58}$. Wśród średniowiecznych uczonych Ryszard był zaliczany do wąskiego grona „mężów zaufania w teologii”"59. Wybór tego właśnie autorytetu możemy jednak potraktować jako element wyróżniający autora denuncjacji. Z pewnością miał on zaufanie do pisarstwa franciszkanina, skoro to właśnie za pośrednictwem jego dzieła, a nie zbioru prawa, przywołał jeden cytat z Dekretu Gracjana. Nie można również wykluczyć, że przywołanie franciszkańskiego teologa było też mniej lub bardziej ukrytą aluzją (i uszczypliwością) w kierunku tomistycznego wykształcenia Mikołaja ${ }^{60}$.

Czwarty artykuł omawianej denuncjacji jest wyjątkowy. Jak wiemy, nasz autor nawet wobec doniesień o rzekomym głoszeniu przez dominikanina błędnej teologii Eucharystii zachował spokój i merytorycznie przedstawiał swoje racje. Tu jednak zmienił taktykę i język. Chodziło o jedną z wypowiedzi brata Mikołaja, publicznie kwestionującego kompetencje doktorów i mistrzów uniwersyteckich, którzy „nic nie wiedzą" (nihil sciunt). Pogłoska osobiście dotknęła naszego autora, który w przygotowanym komentarzu postanowił w nowy i oryginalny sposób wykazać błąd dominikanina. Tym razem nie przywołał żadnego autorytetu, ani prawniczego, ani teologicznego, ale precyzyjnie zidentyfikował, jakie motywy przyświecały kaznodziei i jak tragiczne konsekwencje wywołują tego rodzaju poglądy. W celu wywarcia

${ }^{58}$ Richardus de Mediavilla, Super IV libros sententiarum, lib. IV, dist. 9, a. 1, q. 1, arg. 2, resp. ad 2 (Brixiae 1691, t. IV, s. 108b-109a).

59 S. S w i e ż a w s k i, Dzieje filozofii europejskiej w XV wieku, t. IV, Warszawa 1979, s. 91, przyp. 43 (tam też obszerna literatura).

${ }^{60}$ Przypomnę, że Ryszardowi z Middletown w wielu kwestiach teologicznych było bliżej do św. Bonawentury niż św. Tomasza z Akwinu, zob. R. Z a v a 11 o n i, Richard de Mediavilla et la controverse sur la pluralité des formes. Textes inédits et études critiques, Louvain 1951, s. 67-78; H. A n zule wi c z, Um den Kodex Ms. lat. 456 der Staatsbibliothek Preußischer Kulturbesitz zu Berlin. I: Richard von Mediavilla, Franziskanische Studien 74, 1992, s. 19-43; T. G a ł u s z k a, Jan ze Schenkenfeldu - tomista inkwizytorem, w: Proces beginek świdnickich w 1332 roku. Studia historyczne i edycja łacińsko-polska, opr. P. Kras, T. Gałuszka, A. Poznański, Lublin 2017, s. 137-138. 
jeszcze większego wrażenia na czytelniku autor uciekł się do specjalnych zabiegów retorycznych i stylistycznych (art. 4): Quo nititur studium per sedem apostolicam approbatum d e s tru e r e; doctores et magistros, qui auctoritate apostolica creantur, c o $n f u n d$ a re; regi et regno in hoc, quod inscios et ignaros habent pro doctoribus et magistris, d e tra h e re; populum contra uniuersitatem c o n c i t a re et sedicionem fac e re; caritatis dulcedinem, quam habent rex, militia et populus ad eos, infice re; sapiencior omnibus doctoribus ap parere. Wypowiedź dominikanina - według interpretacji autora denuncjacji - była niczym innym, jak podważaniem autorytetu Stolicy Apostolskiej, niszczeniem uniwersytetu, ośmieszeniem grona profesorskiego, zniesławieniem króla i królestwa, podburzaniem ludu i przygotowaniem do rebelii, zatruwaniem doskonałych relacji uniwersytetu z królem, rycerstwem i mieszkańcami. Autor chciał, by czytelnik poznał i zapamiętał pełny wykaz zagrożeń, jakie powoduje działność brata Mikołaja. Służyło temu ujęcie tego fragmentu w fomie wiersza mnemotechnicznego z rymami opartymi na bezokolicznikach ${ }^{61}$. Dowodzi to wysokiej kultury językowej autora. Nie jest to jedyny przykład zastosowania przez niego anafory. Można wręcz stwierdzić, że repetycja była jego ulubionym środkiem stylistycznym, jak pokazują kolejne przykłady - na wstępie: ad ostendendum, quod articuli per me uia denuntiationis oblati quidam sunt iuri contrarii, quidam scandalosi, quidam piarum animarum offensiui, quidam de fide suspecti; w art. 8: quod ex uerbis mordacibus, detractoriis, insipidis et insulsis est relictum; w art. 9: Concluditur quod populum scandalizauit, pias aures offendit, fidei catholice iniuriam non appendens uerba in statera fecerit. Przykłady te świadczą o talencie pisarskim autora, doskonałym opanowaniu łaciny i przygotowaniu retorycznym. Człowiek, który tak umiejętnie i gorliwie zaangażował się w obronę uniwersytetu oraz tak gwałtownie i emocjonalnie reagował na jakiekolwiek słowa krytyki pod adresem tej instytucji, musiał czuć szczególną więź z uczelnią.

Wiemy więc, że nasz autor był człowiekiem wszechstronnie wykształconym, z wysokimi kwalifikacjami w dziedzinie prawa oraz teologii, uzdolnionym stylistą, który nawet w tak niewielkim tekście stosował wyszukane środki stylistyczne, a jego stosunek do uniwersytetu pozwala domniemywać, że był on członkiem tej instytucji. Ponieważ w swojej denuncjacji wielokrotnie przedstawia szereg teoretycznych i praktycznych uwag na temat posługi kaznodziejskiej, jest też bardzo prawdopodobne, że sam był aktywny na tym polu. Dobrze orientował się też w pracy duszpasterskiej lokalnego duchowieństwa diecezjalnego i cieszył się jego zaufaniem. Nie dziwi zatem, że ok. 1421 r. został przez tych duchownych poproszony o reprezentowanie ich interesów przed biskupem Wojciechem Jastrzębcem. Obserwacje te dają wystarczające i solidne podstawy, by omawianą denuncjację dopisać do obszernego zbioru pism prawnika, teologa, kanodziei, pierwszego rektora odnowionego Uniwersytetu Krakowskiego, biskupiego wikariusza generalnego Stanisława ze Skarbimierza ${ }^{62}$.

${ }^{61}$ Warto zauważyć, że w ten sam sposób były tworzone wiersze, pouczające krakowskich studentów i przekazujące im przepisy porządkowe i moralne (H. K o w a le w i c z, Średniowieczna poezja polskich żaków, Pamiętnik Literacki 64, 1973, z. 1, s. 203-204, 212-213).

${ }^{62}$ Literatura na temat Stanisława ze Skarbimierza jest bardzo obfita, zob. zwłaszcza: R. M. Z a w a dzk i, Stanisław ze Skarbimierza, w: Polski słownik biograficzny, t. XLII (2003-2004), s. 76-80; P. K r a s, „Pastor bonus et lupi rapaces”. The Polemic against Hussite 
Nie tylko nie znajdujemy żadnych argumentów, które podważałyby lub choćby osłabiałyby taką propozycję autorstwa, ale wręcz przeciwnie, pojawiają się dodatkowe informacje, które ją potwierdzają i umacniają. W pierwszej kolejności warto przypomnieć, że rękopis BJ 1629 (Kr1) zawiera prawie w całości kazania sapiencjalne Stanisława ze Skarbimierza oraz przypisywaną mu mowę rektorską. Pozostałe zawarte tam pisma to dwa anonimowe traktaty teologiczne oraz interesująca nas denuncjacja. Jej kopista użył tego samego papieru, co pracujący ok. 1417 r. pisarz kazań sapiencjalnych. Obu kopisów łączył zatem jeden warsztat pracy, być może krakowska kancelaria konsystorska Stanisława ze Skarbimierza, który w latach 14021429 pełnił funkcje sądownicze, piastując urzędy oficjała krakowskiego (sierpień 1426), wikariusza generalnego (czerwiec 1419, luty-czerwiec 1422, sierpień 1426) i surogata oficjała (lipiec 1419 - lipiec 1420) ${ }^{63}$. Hipoteza ta dobrze tłumaczy, w jaki sposób pisarz Kr1 miał ok. 1421 r. dostęp do akt sprawy brata Mikołaja, czyli konceptu denuncjacji oraz dominikańskich conclusiones. Samą denuncjację możemy zaś potraktować jako kolejne świadectwo aktywności konsystorskiej Stanisława ${ }^{64}$.

Opisując warsztat teologiczny naszego autora, wspomniałem m.in. o doskonałej znajomości Biblii oraz dość zagadkowym wykorzystaniu przez niego dzieła Ryszarda z Middletown. Roman Zawadzki w swojej klasycznej już monografii o twórczości Stanisława jako pierwszą cechę jego pisarstwa wskazał pamięciowe opanowanie tekstu Pisma św., a jednocześnie pomysłowość w przetwarzaniu tekstu bibljnego w celu wyrażania nowych treści ${ }^{65}$. Przykłady, którymi historyk zilustrował swoją tezę, przypominają zacytowany wyżej fragment prologu denuncjacji. Co się zaś tyczy odniesień do dzieł Ryszarda z Middletown, to przyglądając się opublikowanym dziełom Stanisława, nie dostrzegamy jakiejś szczególnego zainteresowania franciszkańskim teologiem. W aparatach źródłowych edycji kilkuset kazań Stanisława ze Skarbimierza powstałych przed 1415 r. nie odnajdujemy żadnego odniesienia do twórczości Ryszarda ${ }^{66}$. Autor ten nie jest też wspomniany w żadnej z dostępnych drukiem mów rekomendacyjnych Stanisława powstałych w latach $1400-1408^{67}$, ani

Doctrine in the Writings of Stanisław of Skarbimierz, w: Česko-polské kazatelské vztahy ve středověku, Praha 2016, s. 63-79; B. W o j c i e c how s k a, Stanisława ze Skarbimierza rozważania „o dwóch drogach, którymi podąża się do nieba”, w: Ambona. Teksty o kulturze średniowiecza ofiarowane Stanisławowi Bylinie, Warszawa 2016, s. 193-206.

${ }_{63}^{63}$ E. Kn a p e k, Akta, s. 197, 205, 214.

${ }^{64}$ R. M. Z a w a d zk i, Spuścizna, s. 118-123.

${ }_{65}$ Tamże, s. 142-143.

${ }^{66}$ Stanislai de Scarbimiria sermones super „Gloria in excelsis”, wyd. R. M. Zawadzki, Warszawa 1978; Stanisław ze Skarbimierza, Sermones, t. I-III; W. S eń k o, Piotr Wysz z Radolina (* ok. 1354 -+ 1414) i jego dzieło „Speculum aureum”, Warszawa 1995, s. 273-279 (mowa na ingres Piotra Wysza); D. W ó j c i k - Z e g a, W. Z e g a, Stanisława ze Skarbimierza kazanie uniwersyteckie „Nihil tuleritis in via”, Przegląd Tomistyczny 14, 2008, s. 99-134.

${ }^{67}$ J. D o m a ń s k i, Discours d'inauguration fait par Stanislas de Skarbimierz à l'occasion du renouveau de l'université de Cracovie, Mediaevalia Philosophica Polonorum 24, 1979, s. 113-132; R. Tat a r z ý s k i, Stanisława ze Skarbimierza trzy mowy rekomendacyjne, Przegląd Tomistyczny 6-7, 1997, s. 349-384; „Prima verba”. Krakowskie mowy uniwersyteckie, red. E. Jung-Palczewska, Łodź 2000, s. 92-109, 186-199; D. W ó j c i k - Z e g a, W. Z e g a, Stanisława ze Skarbimierza mowa rekomendacyjna „Ecce odor filii mei” na licencjat Macieja z Koła, Przegląd Tomistyczny 17, 2011, s. 201-234. 
też w jego trzech consilia contra Henricum de Brega z 1429 r. ${ }^{68}$ Nie oznacza to jednak, że Stanisław nie znał dzieł Ryszarda. Na jego autorytet powołał się bowiem czterokrotnie, ale - co znamienne - tylko raz, w trakcie przygotowania pierwszego z sześciu traktatów antyhusyckich (determinationes), zaczynającego się od słów $A d$ enervandum errores ${ }^{69}$. Według Zofii Włodek tekst ten powstał w latach 1420-142 $1^{70}$, natomiast Pawłeł Kras datuje go na 1421 r. $^{71}$, a Roman Zawadzki - nawet na 1424 r. ${ }^{72}$ Traktat ten poświęcony był zagadnieniu utrakwizumu. Stanisław, opisując główny powód praktyki udzielania komuniii pod postacią chleba eucharystycznego, tj. niebezpieczeństwo rozlania Krwi Pańskiej, przytoczył trzykrotnie komentarz Ryszarda do Sentencji ${ }^{73}$. Czwarty raz przywołał go w kontekście wykładu słów z Ewangelii według św. Jana $(6,53)$ : Nisi manducaveritis, stwierdzając, że należy je rozumieć jako spożywanie duchowe (manducatio spiritualis). Polski wydawca tego traktatu nie zidentyfikował owego zapożyczenia. Ponad wszelką wątpliwość chodziło zaś o ten sam fragment komentarza Ryszarda, który został obszernie i dosłownie przytoczony w analizowanej krakowskiej denuncjacji.

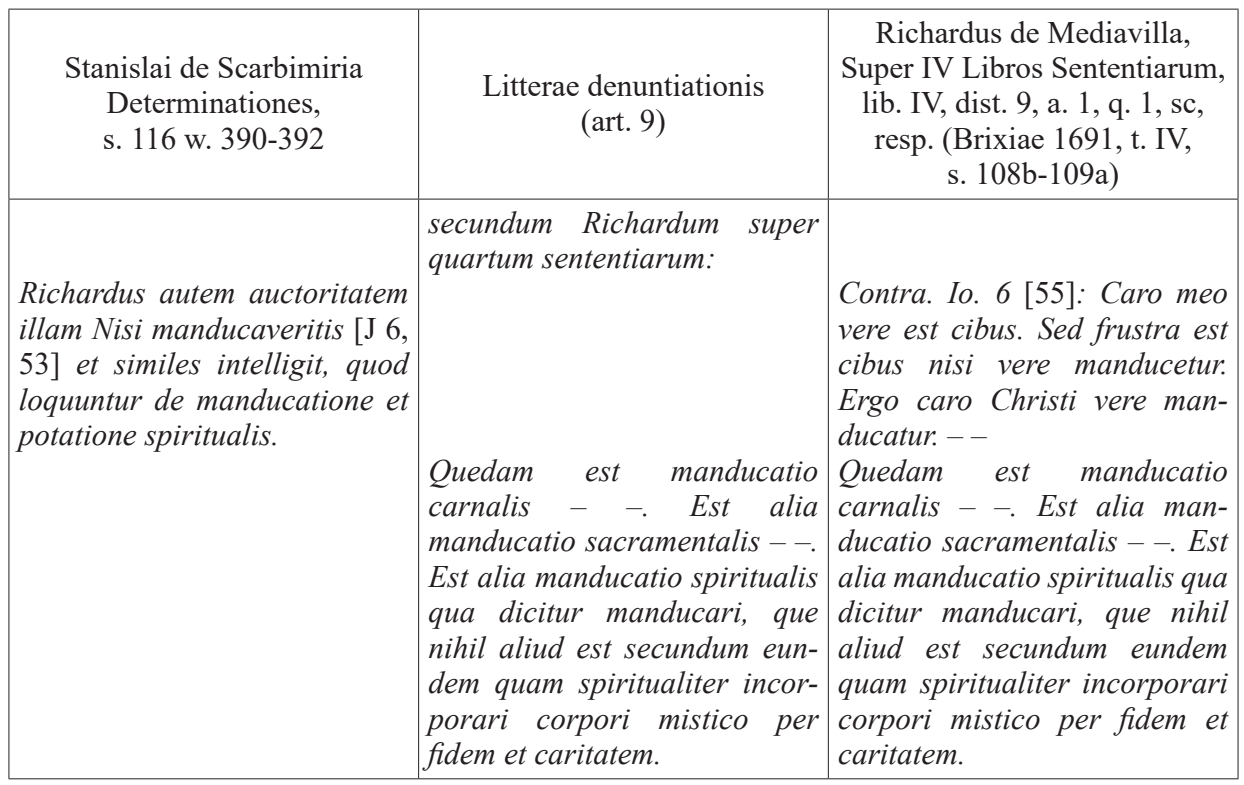

${ }^{68} \mathrm{~S} . \mathrm{W}$ i e $1 \mathrm{~g}$ u s, Consilia de Stanislas de Scarbimiria contre l'astrologue Henri Bohemus, Studia Mediewistyczne 25, 1988, z. 1, s. 145-172.

${ }^{69}$ Stanislai de Scarbimiria determinationes tres, w: „Scripta manent”. Textus ad theologiam spectantes in Universitate Cracoviensi saeculo XV conscripti, opr. Z. Włodek, Kraków 2000, s. 111-119.

70 Z. W ł o d e k, Stanisław ze Skarbimierza i utrakwizm husycki, Przegląd Tomistyczny 9, 2003, s. 142; datację tę przyjął również K. O ż ó g, Uczeni w monarchii Jadwigi Andegaweńskiej i Władysława Jagiełly (1384-1434), Kraków 2004, s. 58.

${ }^{71} \mathrm{P}$. K r a s, „Pastor bonus et lupi rapaces”, s. 74.

${ }_{72}$ R. M. Z a w a d z k i, Stanisław ze Skarbimierza, s. 78.

73 Stanislai de Scarbimiria determinationes, s. 113 w. 303-310, s. 114 w. 336-347, s. 116 w. 392-395. Wydawca nie podał dokładnego zapisu bibliograficznego dzieła Ryszarda: Richardus 
Dodajmy jeszcze, że przywołany wyżej fragment traktatu Stanisława sprawia wrażenie glosy, a nawet nie do końca powiązanego z całością wywodu wtrącenia - tak jakby uczony nagle przypomniał sobie interesujący szczegół z niedawnej lektury Ryszarda z Middletown. Doskonałą sposobnością do tak dobrego poznania i zmemoryzowania byłoby wcześniejsze skopiowanie tej części franciszkańskiego komentarza do własnej denuncjacji. Wykazanie powiązań pomiędzy tą denuncjacją i traktatem Ad enervandum errores dostarcza nam mocny, o ile nie definitywny, argument na rzecz Stanisławowego autorstwa omawianego źródła. Obserwacje te raz jeszcze potwierdzają datowanie denuncjacji na ok. $1421 \mathrm{r}$.

Fragmentem denuncjacji, w którym chyba najbardziej odsłaniają się charakterystyczne cechy osobowości Stanisława, jest artykuł 4, dotyczący lekceważących wypowiedzi brata Mikołaja na temat kadry uniwersyteckiej. Pełen emocji i retorycznej emfazy komentarz staje się zrozumiały, gdy uświadomimy sobie, że został on napisany przez dwukrotnego rektora uniwersytetu (1400, 1413), profesora, współtwórcę statutów zarówno wszechnicy, jak i poszczególnych wydziałów, autora licznych mów, rekomendacji rektorskich i graduałowych, a także kazań uniwersyteckich na różne okazje ${ }^{74}$. W jednym z tych kazań przestrzegał i nazwał głupcami (stulti) tych, którzy twierdziliby: Non sit nobis cura de doctoribus aut doctis, est enim sapientia in nobis ${ }^{75}$. Według Stanisława to właśnie uniwersytet dawał możliwość całościowego rozwoju człowieka pod względem kultury umysłowej i moralności ${ }^{76}$. Nie dziwią zatem ani słowa, ani środki stylistyczne, jakich uczony użył, komentując wypowiedź brata Mikołaja. Ustęp ten ujawnił również umiejętności retoryczne Stanisława. Przytoczony wyżej ,wiersz” możemy uznać za kolejny przykład jego ulubionej maniery pisarskiej, mianowicie - jak zauważył R. Zawadzki - „konstruowanie zdania złożonego, rozbudowanego przez zastosowanie repetycji wyrazowej lub składniowej"77.

Moglibyśmy jeszcze wskazać i omówić kilka innych elementów wskazujących na Stanisławowe autorstwo, jak choćby sygnalizowana już troska autora denuncjacji o jakość posługi kaznodziejskiej czy też zainteresowanie ówczesnymi debatami doktrynalnymi. Na koniec jednak chciałbym zwrócić uwagę na jedną, wydawałoby się, drobną obserwację odnośnie do warsztatu naukowego Stanisława. Autor denuncjacji kilkukrotnie odwołał się do autorytetów patrystycznych, które cytował za pośrednictwem Dekretu Gracjana. Identyczny zabieg Stanisław stosował również w trakcie przygotowywania swych kazań ${ }^{78}$. To szczególne dowartościowanie zbioru prawa kanonicznego w refleksji teologicznej możemy potraktować jako praktyczne przełożenie koncepcji Skarbimierczyka na temat miejsca prawa w hierarchii nauk.

de Mediavilla, Super IV libros sententiarum, lib. IV, dist. 11, q. 4, resp. et ad 1 (Brixiae 1691, t. IV, s. 146b).

${ }^{74}$ R. M. Z a w a d z k i, Spuścizna, s. 113-115; B. C h m i e l o w s k a, Stanislas de Skarbimierz - le premier recteur de l'Université de Cracovie après le renouveau de celle-ci, Mediaevalia Philosophica Polonorum 24, 1979, s. 73-112.

75 Stanisław ze Skarbimierza, Sermones, t. I, s. 109, w. 110-111.

${ }^{76}$ R. M. Z a w a d z k i, Stanisław ze Skarbimierza, s. 77; K. O ż ó g, Uczeni, s. 88-90.

77 R. M. Z aw a d zk i, Spuścizna, s. 143.

${ }^{78}$ D. W ó j c i k-Z e g a, W. Z e g a, Stanisława ze Skarbimierza kazanie uniwersyteckie, s. 104. 
Jak pisał Krzysztof Ożóg: „Jego [tj. Stanisława ze Skarbimierza - TG] zdaniem, kanonistyka, która jest nauką zajmującą się sprawami duchowymi i świeckimi, wiedzie człowieka ku doskonałości - - Stanisław ze Skarbimierza traktował prawo i teologię na równi, bowiem doktorzy dekretów i teologii są dwoma filarami Kościoła"79. Prawnik kościelny był więc zobowiązany nie tylko szukać sprawiedliwości, ale również dbać o zbawienie dusz wiernych. Jednym ze środków formacyjnych była - jak pamiętamy - ewangeliczna correctio fraterna, a w ostateczności także denuntiatio. I ten środek należało zastosować wobec brata Mikołaja.

\section{ZADENUNCJOWANY}

Czytając odpowiedzi (positiones et responsiones) brata Mikołaja, łatwo zauważyć, jak bardzo poczuł się on urażony zarzutami i zaistnieniem całej sprawy. Jego emocje odcisnęły wyraźne piętno zarówno na stylu, jak i zawartości jego pisma. Lista i rodzaj inwektyw, jakich użył wobec głównych denuncjatorów, czyli plebanów, była imponująca: heretici, huszsite, canes, oblocutores, detractores, fatui, fatuelli, in ignorantia permanentes, emuli. Zakonnik dodał jeszcze, że denuncjację złożyli oni non caritatiue sed ex inuidia et longa cordis displicentia. Pewne jest, że miał on świadomość swojej pozycji i nie akceptował aż tak otwartej krytyki swojej działalności. Natomiast interwencja w jego sprawie samego Stanisława ze Skarbimierza sugeruje, że nie chodziło o szeregowego brata z krakowskiego konwentu Św. Trójcy, ale o osobę należącą do elity krakowskich dominikanów. Zanim jednak zaproponuję identyfikację, spróbujmy naszkicować portret brata Mikołaja, jaki wyłania się z tekstu denuncjacji oraz pozycji i konkluzji.

W rękopisie BJ 1629 (Kr1) kopista odnotował jedynie inicjał imienia dominikanina - frater N. Była to, jak sądzę, kolejna ingerencja tego pisarza w kopiowany tekst. Natomiast w rękopisie BJ 1652 (Kr2) imię dominikanina odnajdujemy w pełnym brzmieniu - frater Nicolaus. W przygotowanej przez siebie odpowiedzi (9) stwierdził, że publiczną posługę kaznodziejską prowadził od wielu lat (a multis annis). Najprawdopodobniej więc jego głównym oficjum klasztornym było kaznodziejstwo. Przypomnę, że w dominikańskim klasztorze prawo głoszenia kazań ex officio miał przeor oraz lektorzy teologii, pracujący w szkołach konwentualnych, partykularnych i studium generalnym ${ }^{80}$. Jak pokazują jednak piętnastowieczne rozporządzenia polskich kapituł prowincjalnych, wymienieni oficjaliści z powodu różnych obciążeń administracyjnych i dydaktycznych nie podejmowali regularnego kaznodziejstwa ${ }^{81}$. Do głoszenia kazań byli natomiast specjalnie przeznaczeni kaznodzieje konwentualni i generalni. Praedicator conventualis po odbyciu kilkuletnich (3-5 lat) studiów teologicznych oraz zdaniu egzaminu przed kapitułą prowincjalną otrzymywał

${ }^{79}$ K. O ż ó g, Uczeni, s. 55.

${ }^{80}$ T. M. Trajdos, Kaznodzieje dominikańscy we Lwowie w XV w., w: Kaznodziejstwo średniowieczne - Polska na tle Europy. Teksty, atrybucje, audytorium, Warszawa 2014, s. 141-154; T. K a l i s z, Czy w średniowieczu istniali dominikańscy wędrowni kaznodzieje?, w: Dominikanie w czasach krucjat, katedr i herezji, Poznań 2016, s. 158-168.

${ }^{81}$ Acta capitulorum Provincie Poloniae Ordinis Praedicatorum, t. I, wyd. R. F. Madura, Roma 1972, s. 22, 91. 
nominację kaznodziejską od prowincjała lub wikariusza kontraty. Licencja pozwalała mu na publiczne głoszenie kazań do ogółu wiernych w macierzystym klasztorze oraz kościołach parafialnych należących do jego okręgu kwestarskiego ${ }^{82}$. Na urząd kaznodziei generalnego (praedicator generalis) mianowani byli z kolei głównie bracia spośród najlepszych wykładowców szkół partykularnych oraz zakonników cieszących się nieposzlakowaną opinią i posiadający duże doświadczenie ${ }^{83}$. Mieli oni prawo nauczania wiernych w całej prowincji zakonnej i uczestniczyli w obradach kapituł prowincjalnych ${ }^{84}$. Urząd kaznodziei generalnego mógł być łączony z innymi funkcjami, np. przeora, wykładowcy lub kaznodziei konwentualnego. Warto dodać, że klasztory polskiej prowincji, zwłaszcza w miastach zasiedlanych przez Polaków i Niemców, posiadały zazwyczaj dwóch oficjalnych kaznodziejów konwentualnych, głoszących dla dwóch grup językowych ${ }^{85}$. Oprócz wypełniania obowiązków kaznodziejskich we własnym klasztorze, dominikanie działali również w kościołach parafialnych i katedrach. W krakowskiej katedrze dominikanie zwyczajowo głosili kazania w ważniejsze święta, a szczególnie w Wielkim Poście - w tzw. dni stacyjne (stationes) - oraz podczas obchodów Triduum Paschalnego ${ }^{86}$. Wspomnijmy, że katedralne kazania braci wywoływały nieraz kontrowersje. Sławna jest sprawa lektora Pawła, który w 1361 r. w wygłoszonym po polsku kazaniu do duchowieństwa i ludu zaprzeczał Niepokalanemu Poczęciu Najświętszej Maryi Panny - i zaraz zmarł nagłą śmiercią ${ }^{87}$. Sto lat później zastrzeżenia kapituły katedralnej co do kazań mendykanckich były na tyle duże, że wystosowała ona nawet specjalny list do przełożonych, prosząc o przysyłanie braci odpowiednio wykształconych i zdolnych głosić Słowo Boże na wyższym poziomie ${ }^{88}$.

${ }^{82}$ T. M. Trajd o s, Kaznodzieje, s. 141; T. G a ł u s z k a, Podział dominikańskich okręgów klasztornych na Kujawach w XIV wieku. Studium historyczne i edycja tekstu widymatu prowincjała Ludolfa z 1517 roku, Roczniki Historyczne 80, 2014, s. 67-88.

${ }_{83}$ T. G a ł u s z k a, Szkolnictwo konwentualne i partykularne w strukturach polskiej prowincji dominikanów XIV stulecia. Nowe ujęcie w świetle nowych źródeł, Roczniki Historyczne 78, 2012, s. 199.

${ }^{84}$ T. M. Tr a j d o s, Kaznodzieje, s. 141-144.

${ }^{85}$ Tamże, s. 146; J. Kł o c z ow s ki, Polska prowincja dominikańska w średniowieczu i Rzeczypospolitej Obojga (wielu) Narodów, Poznań 2008, s. 159-178. W trakcie realizowanego obecnie projektu pt. Słownik biograficzny polskich mendykantów w średniowieczu. Dominikanie (NPRH, nr 11 H 120169 81), zidentyfikowani zostali wśród dominikanów XV w. 29 praedicatores Polonorum i 28 praedicatores Alemanorum.

${ }^{86}$ J. W o 1 n y, Krakowskie środowisko katedralne w czasach Jana Długosza (1431-1480), w: Dlugossiana. Studia historyczne w pięćsetlecie śmierci Jana Długosza, Warszawa 1980, s. 97-99; K. O ż ó g, Relacje mendykantów ze środowiskiem dworskim oraz katedralnym na Wawelu do końca XV wieku, w: Mendykanci w średniowiecznym Krakowie, Kraków 2007 (Studia i Źródła Dominikańskiego Instytutu Historycznego w Krakowie 4), s. 30-31. Podobnie w katedrze wrocławskiej w Wielki Czwartek i Wielki Piątek dominikanie i franciszkanie głosili kazania do ludu oraz słuchali spowiedzi (K. D o l a, Liturgia wielkiego tygodnia w katedrze wrocławskiej w XV wieku, Studia Teologiczno-Historyczne Śląska Opolskiego 7, 1979, s. 210).

${ }^{87}$ Ioannis Dlugossi Annales seu cronicae inclicti Regni Poloniae, lib. IX, Warszawa 1978, s. 306; zob. K. K a c z m a r e k, Szkoły i studia polskich dominikanów w okresie średniowiecza, Poznań 2005, s. 419, nr 67.

${ }^{88}$ Acta capitulorum Cracoviensis et Plocensis selecta, wyd. B. Ulanowski, Archiwum Komisji Historycznej, t. VI, Kraków 1891, s. 35, nr 146. 
Informacja o obecności dominikańskich kaznodziejów w katedrach w Wielkim Poście jest istotna w kontekście sprawy brata Mikołaja. Według relacji dominikanina to właśnie po kazaniu wygłoszonym przez niego w Wielki Czwartek (feria quinta bona) został on zniesławiony i potraktowany jak heretyk. I chociaż nie wiemy, czy zakonnik wygłosił swoje wiekoczwartkowe kazanie w kościele Św. Trójcy czy krakowskiej katedrze, jest pewne, że zgromadziło ono wielu słuchaczy i wywołało - jak pisał autor denuncjacji - wielki skandal. Stanisław ze Skarbimierza nie krył rozczarowania kaznodziejstwem brata Mikołaja. Frustracja uczonego musiała być tym większa, że brat Mikołaj - co sam dwukrotnie podkreślił - otrzymał specjalne pełnomocnitwo (mandatum) od inkwizytora papieskiego, by głosić kazania przeciwko „nowym herezjom” (propter novas hereses). Należał on zatem do grona bliskich współpracowników inkwizytora.

Zgodnie ze wskazówkami podanymi w Directorium inquisitorum autorstwa dominikanina Mikołaja Eymericha, inkwizytor mógł i powinien (potest et debet) wyznaczyć na terytorium diecezji jednego zastępcę, zwanego też komisarzem (vicarius, commissarius) $^{89}$. Inkwizyor mógł przekazać zastępcy pełną władzę (plena facultas, plenaria potestas) odnośnie do wszystkich etapów przewodu sądowego w postępowaniu inkwizycyjnym in causa fidei, mógł też przekazać mu ograniczone kompetencje lub wyznaczać go do konkretnych zadań. Oprócz zastępcy inkwizytor mógł korzystać ze wsparcia asystenta (socius $)^{90}$. Taki socjusz pochodził z tej samej wspólnoty zakonnej, co inkwizytor, i był wyznaczany przez generała zakonu lub prowincjała. Pełnił on funkcję doradcy inkwizytora, osobistego spowiednika i sekretarza oraz - o ile posiadał stosowne wykształcenie - notariusza w trakcie procesu. Warto dodać, że socjusz dzięki doświadczeniu, jakie zdobywał u boku inkwizytora, stawał się w przyszłości naturalnym kandydatem do pełnienia tego urzędu' ${ }^{91}$.

Ponieważ brat Mikołaj nie ujawnił, czy był komisarzem czy też socjuszem inkwizytora, musimy przyjąć, że jego pełnomocnitwo ograniczało się jedynie do pierwszego etapu postępowania inkwizycyjnego - praedicatio generalis ${ }^{92}$. Według Mikołaja Eymericha tego typu praedicatio powinno się głosić na terenach (parafia, diecezja itp.) zagrożonych lub dotkniętych herezją. Kaznodzieją był sam inkwizytor lub wyznaczony przez niego kapłan ${ }^{93}$. Głosili oni kazania przez jedną lub kilka niedziel, jednakże poza okresem Wielkiego Postu i Adwentu oraz niedzielami przypadającymi w uroczystości i święta ${ }^{94}$. W kazaniu inkwizycyjnym przypominano o konieczności obrony wiary, zagrożeniach związanych z herezją, wzywano do

${ }^{89}$ Nicolaus Eymerich, Directorium inquisitorum, p. III, Venetiis 1595, s. 403, 545-550; L. P a o lin i, Il „De officio inquisitionis”. La procedura inquisitoriale a Bologna e Ferrara nel Trecento, Bologna 1976, s. 16.

${ }^{90}$ Nicolaus Eymerich, Directorium, s. 551.

${ }^{91}$ Tak było choćby w przypadku czternastowiecznego inkwizytora tuluskiego Falco de Sancto Georgio, który był longo tempore socius inquisitoris Carcassonensis (A. F ri e d l a n d e r, Processus Bernardi Delitiosi: The Trial of Father Bernard Delicieux, 3 September - 8 December 1319, Philadelphia 1996, s. 275).

92 P. K r a s, „Ad abolendam”, s. 193-194.

${ }^{93}$ Taką możliwość przewiduje np. anonimowy podręcznik De officio inquisitionis z $1320 \mathrm{r}$.

(L. P a o 1 i n i, Il „De officio inquisitionis”, s. 130).

${ }^{94}$ Nicolaus Eymerich, Directorium inquisitorum, s. 4077. 
pokuty i dobrowolnego przystąpienia do spowiedzi, ale również pouczano na temat władzy i jurysdykcji inkwizytorów ${ }^{95}$. Słuchacze byli również zachęcani do stawienia się przed inkwizytorem i wyznania własnych win lub zgłoszenia ex caritate zarzutów wobec postępowania innych ${ }^{96}$. Kaznodzieja miał wszelkimi dostępnymi środkami merytorycznymi i retorycznymi ,skruszyć” sumienia swoich słuchaczy i skłonić do porzucenia herezji. Jeżeli chodzi o środki zastosowane przez brata Mikołaja, jak choćby publiczne nazywanie swoich oponentów heretykami i husytami, były one dość kontrowersyjne. Ich obecność dobrze pokazuje jednak, jak bardzo krakowski dominikanin przejął się funkcją współpracownika inkwizytora.

Jednak emocjonalność dominikanina nie wyklucza możliwości, że skoro została mu powierzona praedicatio generalis w Krakowie, to raczej posiadał on odpowiednie przymioty intelektualne i autorytet jako kaznodzieja. Analiza przygotowanego przez niego tekstu odpowiedzi pozwala jedynie na sformułowanie kilku ogólnych wniosków dotyczących jego wykształcenia i warszatu naukowego. Mikołaj, pisząc swą odpowiedź, skorzystał zapewne z trzech kodeksów, zawierających dzieła dwóch trzynastowiecznych dominikanów: Wincentego z Beauvais i Tomasza z Akwinu. W odpowiedzi na trzeci artykuł denuncjacji przytoczył co prawda explicite autorytet Biblii, Glosy ordynaryjnej oraz Dekretu Gracjana, ale w rzeczywistości wszystkie one zostały przywołane za pośrednictwem Tomasz z Akwinu (Contra impugnantes Dei cultum et religionem ${ }^{97}$. Wybór tego autora i konkretnie tego właśnie tytułu nie dziwi. Dziełko to bowiem było poświęcone obronie życia mendykanckiego przed atakami ze strony kleru diecezjalnego ${ }^{98}$. Sposób, w jaki brat Mikołaj skonstruował swoją odpowiedź, wprost sugeruje, że do tego właśnie tekstu Tomasza sięgał nie po raz pierwszy. Swoją odpowiedź uzupełnił ponadto jeszcze krótkim wyjaśnieniem, jakie odnalazł w encyklopedycznym Speculum morale pióra Wincentego z Beauvais ${ }^{99}$. Do twórczości Tomasza $\mathrm{z}$ Akwinu nasz dominikanin powrócił $\mathrm{w}$ trakcie pisania odpowiedzi na ostatni zarzut. Tym razem inspiracji poszukał w trzeciej części Summy teologii ${ }^{100}$. Nie tylko dokładnie przestudiował jeden artykuł tego dzieła, ale własnymi słowami precyzyjnie oddał istotę wykładu Akwinaty. Dodam jeszcze, że w odpowiedzi Mikołaja natrafiamy na jeszcze jedno nawiązanie do dzieła przypisywanego w średniowieczu Tomaszowi z Akwinu, mianowicie komentarza do Księgi Rodzaju ${ }^{101}$. Na podstawie tych kilku obserwacji możemy przyjąć, że brat Mikołaj był wierny tomistycznej szkole teologicznej. Biorąc natomiast pod uwagę użyte przez niego źródła, sposób argumentacji i poprawność językową, nic

${ }_{95}$ Ch. C a ldwe 11 A m e s, Inkwizycja i bracia św. Dominika. Słuszne prześladowanie, tłum. A. Gomola, Poznań 2013, s. 86-92.

96 P. K r a s, „Ad abolendam”, s. 190-191, 194.

${ }_{97}$ Thomas de Aquino, Contra impugnantes, c. 3 (ed. Commissio Leonina, t. XLI, s. A68, w. 451-454); c. 24, arg. 4, ad 4 (s. A140, w. 24-32, s. A141, w. 132-138).

98 J.-P. To r r e 11, Tomasz z Akwinu - człowiek i dzieło, tłum. A. Kuryś, Warszawa 2008, s. $104-109$.

99 Vincentius Bellovacensis, Speculum Morale, p. I, lib. III, dist. 4 (Duaci 1624, kol. 787b).

100 Thomas de Aquino, Summa theologiae, Pars IIIa, q. 80, a. 3, resp., et ad 3 (ed. Commissio Leonina, t. XII, Romae 1904, s. 230-231).

101 (Pseudo-)Thomas de Aquino, Postilla in Librum Genesim, c. 6 (Opera omnia, t. VI, Parisiis 1876, s. 51a). 
nie stoi na przeszkodzie, by widzieć w nim co najmniej absolwenta partykularnej szkoły teologii ${ }^{102}$.

Mówiąc o wykształceniu brata Mikołaja, warto powrócić jeszcze do tekstu denuncjacji. W siódmym artykule Stanisław stwierdził, że język, jakiego używał dominikanin, nie tylko nie przystoi posłudze kaznodziejskiej, ale nawet rozmowom w karczmie. Zasugerował przy tej sposobności, by brat Mikołaj legat enim et relegat omnia uolumina doctorum. Zachęta do ponownego przeczytania dzieł teologów sugeruje, że według autora denuncjacji nasz zakonnik raczej nie był ignorantem, ale kimś, kto posiada już wiedzę i powinien ją sobie powtórzyć i uporządkować. Natomiast w kolejnym, ósmym artykule autor denuncjacji, zastanawiając się generalnie nad publiczną działalnością brata Mikołaja, retorycznie zapytał: Que enim edificatio discipuli potest surgere ex magistri furia, conuiciis, uituperiis? Oczywiście użyty przez Stanisława termin magister w stosunku do dominikanina nie musi oznaczać stopnia naukowego lub godności akademickiej. Przywołanie bowiem obrazu nauczyciela i uczniów miało raczej podkreślić, jak bardzo postawa dominikanina kłóci się ze sprawowaną godnością ewangelicznego kaznodziei. Tym zaś, co najbardziej dotknęło Stanisława w wypowiedziach dominikanina, było rzekome krytykowanie przez niego kadry uniwersyteckiej (art. 4). Jednak brat Mikołaj w swojej odpowiedzi (ad 4) jednoznacznie zdementował doniesienie, że kiedykolwiek wypowiadał się na temat kompetencji profesorów. Wyjaśnił, że w swoim kazaniu krytykował wyłącznie niewiedzę plebanów, którzy pomimo obecności profesorów w Krakowie, w ogóle nie korzystali z ich wiedzy. Według dominikanina zagrożeniem dla prawa nie jest człowiek uczony (vir doctus), ale „tacy mali głupcy” (tales fatuelli), czyli oskarżający go plebani. Widzimy zatem wyraźnie, że zaistnienie czwartego zarzutu było wynikiem albo nieporozumienia, albo złej woli ze strony denuncjatorów. Lektura tego artykułu oraz odpowiedzi dominikanina ujawnia jeszcze jeden szczegół: Stanisław pisał mianowicie o Mikołaju jako osobie spoza uniwersytetu, atakującej go z zewnątrz. Dominikanin również pisał o uniwersytecie z perspektywy człowieka, który co prawda szanuje wspólnotę akademicką, ale do niej nie należy. Obserwacja ta - jak zobaczymy dalej - będzie ważna w kontekście identyfikacji brata Mikołaja.

Kilka słów komentarza wypada poświęcić jeszcze konkluzjom, które - jak zaznaczył kopista rękopisu Kr1 - frater Nicolaus publice coram populo proponet. Pismo to pokazuje nam zupełnie inne oblicze dominikanina. W trakcie krytyki tekstu wspomniałem, że w pięciu na sześć konkluzji (1-3, 5-6) przytoczone zostały prawie dosłownie fragmenty statutów synodalnych, a trzeba dodać, że również ostatnia, siódma konkluzja została skonstruowana z zapożyczeń z listu denuncjacyjnego. Do denuncjacji autor sięgnął również przy przygotowaniu drugiej konkluzji. Generalnie conclusiones są kompilacją tekstów z niewielką liczbą autorskich komentarzy. Brak w nich jakichkolwiek odniesień do źródeł i argumentacji z odpowiedzi, ale również charakterystycznego dla dominikanina „buńczucznego stylu”. Co więcej, w drugiej konkluzji brat Mikołaj nawet pokornie przyznał, że sposób, w jaki krytykował plebanów, był niewłaściwy i zasługujący na karę (pena dignus). Czytając

102 T. G a ł u s z k a, Szkolnictwo, s. 200-202. 
to pismo, można odnieść wrażenie, że autorem tekstu nie był brat Mikołaj, ale ktoś zupełnie inny. Nie ulega wątpliwości, że Mikołaj odczytał publicznie te konkluzje jako własne stanowisko i najprawdopodobniej zgodził się z ich treścią, tym bardziej że w większości zawierały one oficjalne nauczanie Kościoła powszechnego i bardzo korzystny dla mendykantów 20 rozdział artykułów synodalnych. Przypuszczam jednak, że konkluzje, choć zapewne stanowią kompromis wypracowany przez dominikanina i składającego denuncjację, swój ostateczny kształt nabrały w kancelarii konsystorskiej. Hipotezę tę może potwierdzać następująca obserwacja. Autor drugiej konkluzji niewątpliwie musiał być biegłym dekretalistą, skoro zmienił pierwotny tekst drugiego punktu wspomnianego artykułu synodalnego z: ex fomite invidie, odii et rancoris, na inspirowaną komentarzem Hugoccia do Dekretu Gracjana wersję: ex fomite odii uel zelo ultionis ${ }^{103}$. Wspomnę, że wykład włoskiego kanonisty dotyczył sposobów i motywacji reagowania na doznaną krzywdę. Była to bezpośrednia aluzja do niewłaściwych metod, jakie stosował pozwany dominikanin w publicznej krytyce plebanów.

Z zebranych informacji wyłania się ciekawy portret brata Mikołaja: miał on odpowiednie wykształcenie i doświadczenie duszpasterskie; od kilku lat głosił w Krakowie kazania do ludu i współpracował z inkwizytorem w zakresie głoszenia praedicationis generalis; w środowisku krakowskiego duchowieństwa zajmował wysoką pozycję, czego był w pełni świadomy; jak ważną był osobistością, najlepiej pokazuje wszczęcie przeciwko niemu procesu, w który zaangażował się były rektor, profesor prawa i praktykujący kaznodzieja Stanisław ze Skarbimierza. Wadami Mikołaja były zapewne impulsywność, konfliktowość, a zwłaszcza niefrasobliwość w mowie. Spróbujmy zatem zidentyfikować pozwanego dominikanina.

Dzięki prowadzonym od kilku lat badaniom nad prozopografią klasztoru Św. Trójcy posiadamy informacje o siedmiu braciach Mikołajach, mieszkających tutaj w latach 1420-1425. Byli to: Mikołaj zakrystianin, Mikołaj z Brześcia, Mikołaj Lipoldowic, Mikołaj z Łęczycy, Mikołaj Olan, Mikołaj z Pniew, Mikołaj Wójt (Woyt ${ }^{104}$. Ponieważ pozwany dominikanin przyznał, że głosił kazania „od wielu lat”, z naszych poszukiwań możemy wykluczyć Mikołaja Olana i Mikołaja z Łęczycy, którzy dopiero w drugiej połowie $1421 \mathrm{r}$. otrzymali asygnaty do zakonnego studium generalnego w Krakowie na stanowiska kursora i sentencjariusza ${ }^{105}$. Na temat Mikołaja Wójta nie mamy żadnych dodatkowych informacji, poza faktem, że w 1422 r. był członkiem konwentu ${ }^{106}$. Mikołaj zakrystianin sprawował tę funkcję w latach 1425 1434 i trudno sobie wyobrazić, by łączył ją z posługą kaznodziei konwentualnego

${ }^{103}$ Hugoccio, Summa decretorum ad Decretum Gratiani, p. II, C. XXIII, q. 4, c. 1 (ed. E. Friedberg, t. I, kol. 899): Vindicta quandoque infertur ex odio et zelo ultionis et non iusticie, quandoque infertur amore correctionis et afflictorum liberationis; cyt. za: H. W a $1 \mathrm{t}$ h e r, Häresie und päpstliche Politik: Ketzerbegriff und Ketzergesetzgebung in der Übergangsphase von der Dekretistik zur Dekretalistik, w: The Concept of Heresy in the Middle Ages (11th-13th C.), Louven 1983, s. 127, przyp. 90.

104 Zob. wyżej, przyp. 85.

${ }^{105}$ K. K a c z m a r e k, Szkoły, s. 523 nr 361, s. 526, nr 371, s. 533-534 nr 403; M. Z d a n e k, Szkoły, s. 166, 171, 180. Zob. P. Kra s, Husyci w piętnastowiecznej Polsce, Lublin 1998, s. 269-270, który błędnie utożsamił Mikołaja z Łęczycy z Mikołajem z Brześcia.

106 Archiwum Kurii Metropolitalnej w Krakowie, AOff. 4, k. 246v (s. 496). 
i współpracownika inkwizytora ${ }^{107}$. Z tych samych powodów pozwanym nie mógł być Mikołaj z Pniew, który w latach 1419-1431 piastował nieprzerwanie urząd prowincjała $^{108}$. Na naszej liście pozostało zatem już tylko dwóch braci, których biografie wymagają nieco większej uwagi.

Mikołaj Lipoldowic po odbytych w latach siedemdziesiątych XIV w. studiach w Pizie lub Sienie rozpoczął pracę dydaktyczną w polskich ośrodkach studiów, najpierw w Raciborzu, a od 1410 r. również w Krakowie, gdzie został ustanowiony wykładowcą sentencji109. Co szczególnie dla nas ważne, w 1384 r. kapituła prowincjalna ustanowiła go kaznodzieją generalnym ${ }^{110}$. Według przypuszczeń Pawła Kielara OP, dominikanin ten od lat dziewięćdziesiątych utrzymywał bliskie kontakty z Uniwersytetem Krakowskim i nawet został wykładowcą na Wydziale Sztuk ${ }^{111}$. Na takie związki rzeczywiście mógłby wskazywać zapis z 1420 r. w metryce uniwersyteckiej, w której Mikołaj występuje jako magister sztuk i bakałarz teologii. Ostatnia prawdopodobna wzmianka na jego temat pochodzi z 1422 r., kiedy wystąpił jako „profesor teologii i były przeor krakowski" ${ }^{112}$. W momencie złożenia denuncjacji ok. 1421 r. Mikołaj mógł zatem liczyć sobie ponad 70 lat. Nie można wykluczyć, że oprócz pracy dydaktycznej nadal prowadził także działalność kaznodziejską, w ramach której mógł współpracować z inkwizytorem papieskim. Z pewnością był człowiekiem rozpoznawanym w Krakowie, choćby z powodu zamieszkiwania tutaj od ponad 10 lat. Czy więc był on tożsamy z zadenuncjowanym bratem Mikołajem? Taką hipotezę osłabiają dwie obserwacje. Obciążenie pracą dydaktyczną wydaje się utrudniać, o ile nie wykluczać, regularne głoszenie publicznych kazań. Z kolei jego bliskie relacje z uniwersytetem skutecznie podważają domysł, że ktoś mógłby go oskarżyć o tak otwarte i ostre krytykowanie tej instytucji. Doniesienie, że brat Mikołaj Lipoldowic gardzi własnym środowiskiem akademickim, byłoby z pewnością uznane za absurdalne kłamstwo.

107 Zbiór dokumentów małopolskich, t. II, wyd. S. Kuraś, Wrocław 1963, nr 378, 435, 468; ostatni dokument jest falsyfikatem, o czym M. Z d a n e k, Inkwizytorzy dominikańscy w diecezji krakowskiej w średniowieczu, w: Inkwizycja papieska w Europie Srodkowo-Wschodniej, Kraków 2010 (Studia i Źródła Dominikańskiego Instytutu Historycznego w Krakowie 7), s. 232 , przyp. 26.

${ }_{108}$ Tamże, s. 232, nr 6. Autor ten utożsamił Mikołaja z Pniew ze wzmiankowanym w dokumencie z 7 VII 1425 r. „Mikołajem, byłym prowincjałem i kaznodzieją dla Polaków” (Zbiór dokumentów małopolskich, t. II, nr 378). Hipoteza ta jest trudna do przyjęcia, gdyż zakładałby najpierw usunięcie Mikołaja z Pniew z urzędu na majowej kapitule generalnej, o czy nie mamy żadnych informacji, a następnie jesienią tego samego roku przywrócenie go na ten urząd przez polską kapitułę prowincjalną. W dokumencie z 1425 r. chodzi zatem o innego byłego prowincjała, którego identyfikuję z Mikołajem z Brześcia, zarządzającym polskimi dominikanami w latach 1417-1419.

${ }_{109}$ K. K a c z m a r e k, Szkoły, s. 417 nr 59; M. Z d a n e k, Szkoły, s. 103, 107, 171 przyp. 7; G. K u bli n, Piśmiennictwo średniowiecznych dominikanów związanych z klasztorem w Raciborzu, Przegląd Piśmiennictwa Teologicznego 21, 2015, s. 14-16.

${ }^{110}$ Cracovia artificium. Supplementa, wyd. B. Przybyszewski, Wrocław 1985, nr 171. M. Z d a n e k, Szkoły, s. 170, przyp. 7.

${ }_{111}$ P. K i e 1 a r, Mikołaj Lypoldi dominikanin magister artium i bakałarz teologii, w: Studia nad historią dominikanów w Polsce, t. I, Warszawa 1975, s. 420-423, zwłaszcza przyp. 8.

112 Zob. wyżej, przyp. 109. 
Ostatnim „kandydatem” na głównego bohatera denuncjacji jest Mikołaj Aurifabri z Brześcia. Po raz pierwszy w źródłach pojawia się dopiero w marcu 1418 r. i od razu jako prowincjał, najwyższy urzędnik w polskiej prowincji ${ }^{113}$. Stanowisko to objął na jesiennej kapitule prowincjalnej w 1417 r., kilka miesięcy po przyjęciu infuły przez poprzednika, Jana Biskupca z Opatowca ${ }^{114}$. Biorąc pod uwagę biografie wcześniejszych prowincjałów, możemy przyjąć, że był on człowiekiem wykształconym, legitymującym się co najmniej tytułem lektora teologii oraz posiadającym doświadczenie organizacyjne, zdobyte w trakcie wcześniejszych kadencji przeorskich ${ }^{115}$. Swoje urzędowanie rozpoczął w czasie niełatwym dla polskich dominikanów. W $1415 \mathrm{r}$ grupa braci podjęła udaną próbę podziału polskiej prowincji na dwie: polską i dolnoniemiecką. Po dwóch latach walk dzięki wysiłkom Jana Biskupca udało się w 1417 r. przywrócić jedność ${ }^{116}$. Mikołaj z Brześcia otrzymał trudne zadanie odbudowy zaufania wewnątrz prowincji i złagodzenia konfliktów. Musiał stawić czoła nie tylko różnym separatyzmom, które tliły się wśród braci, ale także spełniać nałożone mu przez prawo zakonne obowiązki ordynariusza prowincji, czyli administrować, wizytować klasztory oraz dbać o jak najwyższe standardy życia zakonnego. Z pewnością nieraz miał okazję usłyszeć o licznych problemach, z jakimi borykali się bracia w pracy duszpasterskiej, zwłaszcza o konfliktach z klerem diecezjalnym. Jako prowincjał utrzymywał ponadto kontakty z generałem zakonu, władzami kościelnymi i świeckimi. Nie wiemy, czy wyzwanie to przerosło Mikołaja, czy też niechęć braci była tak duża, ale kapituła generalna w 1419 r. podjęła decyzje o usunięciu go z urzędu, a wikariuszem prowincji ustanowiła Mikołaja z Pniew, który niedługo potem został wybrany na prowincjała ${ }^{117}$. Jako były prowincjał Mikołaj z Brześcia pozostał w domu prowincjalnym, czyli konwencie krakowskim ${ }^{118}$. Znamienne, że po zejściu z urzędu prowincjała nie zaprzestał działalności publicznej, ale przeniósł się na krakowską ambonę jako oficjalnie mianowany kaznodzieja dla Polaków ${ }^{119}$. Zapewne też dzięki wcześniejszym funkcjom cieszył się dużym autorytetem w lokalnym środowisku. Jego zaangażowanie w działalność kaznodziejską i obronę doktryny Kościoła zostały dostrzeżone przez przełożonych zakonnych i ok. 1428/1429 r., po śmierci inkwizytora papieskiego Jana z Polski, otrzymał nominację na ten urząd od prowincjała Mikołaja z Pniew ${ }^{120}$. Mikołaj z Brześcia był zatem kolejnym byłym dominikańskim

${ }_{113}$ Kraków, Archiwum Polskiej Prowincji Dominikanów, Śr 1.

114 J. Tu re k, Jan Biskupiec, prowincjał polskich dominikanów w latach 1411-1417, w: Ecclesia, regnum, fontes. Studia z dziejów średniowiecza, Warszawa 2014, s. 87-95.

115 T. G a ł u s z k a, Podział, s. 116. Być może był tożsamy z Mikołajem przeorem w Poznaniu (1410) i Żninie (1415), zob. Zbiór formuł zakonu dominikańskiego, wyd. J. Fijałek, Kraków 1938, nr 112; Gniezno, Archiwum Archidiecezjalne, ACons. A 5, k. 10 (1415).

116 J. Tu rek, Podział polskiej prowincji dominikanów w czasach prowincjalatu Jana Biskupca w latach 1415-1417, Przegląd Historyczny 106, 2015, s. 289-324.

117 Tamże, s. 307.

118 Acta scabinalia Casimiriensia 1407-1427, wyd. B. Wyrozumska, Kraków 1996, nr 2283.

119 Zbiór dokumentów małopolskich, t. II, nr 378.

120 Tamże, nr 435 (7 VII 1431). Przekazu tego nie odnotowali P. K r a s, Dominican Inquisitors in Medieval Poland (14th-15th c.), w: Praedicatores, Inquisitores, I. The Dominicans and the Medieval Inquisition. Acts of the 1st International Seminar on the Dominicans and the Inquisition. Rome, Roma 2004, s. 298 nr 10, 304 nr 24; t e n ż e, Działalność inkwizycyjna 
prowincjałem, który w średniowieczu objął urząd inkwizytora ${ }^{121}$. W latach trzydziestych XV w. mamy tylko jedno świadectwo jego działalności inkwizytorskiej. Około 1431 r. Mikołaj wspólnie z biskupem i rektorem Uniwersytetu Krakowskiego ogłosili akcję poszukiwania wśród studentów książek proweniencji husyckiej ${ }^{122}$. Według Jana Długosza i części historiografii Mikołaj z Brześcia sprawował urząd inkwizytora jeszcze w latach 1440-1463, łącząc go z funkcją przeora krakowskiego (1451-1453) i ponownie prowincjała (1450-1451) ${ }^{123}$. Długoszowa identyfikacja budzi jednak uzasadnione wątpliwości z przyczyn chronologicznych ${ }^{124}$.

Widać, że biografia Mikołaja z Brześcia jest zdumiewająco zbieżna z przedstawionym wcześniej portretem zadenuncjowanego brata Mikołaja. Nawzajem się uzupełniają i wyjaśniają. Zwróćmy uwagę raz jeszcze na takie choćby elementy, jak wykształcenie teologiczne, wysoka pozycja, posługa kaznodziejska, zaangażowanie w działalność inkwizytorską, znajomość kontrowersji pastoralnych, a wreszcie najprawdopodobniej podobne cechy charakteru. Akta sprawy z ok. 1421 r. pokazują, że brat Mikołaj był niewątpliwie osobistością w lokalnym środowisku (np. jako były prowincjał), a równocześnie nie pełnił już tak eksponowanego urzędu (np. jako prowincjał), by nie można było złożyć na niego skargi. W świetle tych obserwacji możemy z bardzo dużym prawdopodobieństwem zidentyfikować bohatera denuncjacji z ok. 1421 r. z byłym prowincjałem i przyszłym krakowskim inkwizytorem Mikołajem Aurifabri z Brześcia.

\section{POWÓD DENUNCJACJI}

Mikołaj z Brześcia, wyraźnie zaskoczony, w odpowiedzi na ostatni zarzut stwierdził: Numquam fui impeditus ab eis pro ista materia nisi anno isto sum diffamatus tamquam hereticus. Przez wiele lat bowiem głosił kazania na temat teologii Eucharystii i piętnował ,nowe herezje” (novae haereses), ale dotychczas nigdy nie wywoływały one żadnych kontrowersji. Wszystko zmieniło się dopiero „w tym roku” (anno isto) po kazaniu w Wielki Czwartek (feria quinta bona). Zdziwienie Mikołaja było w pełni uzasadnione. Domyślał się bowiem, że oskarżenie go o głoszenie nieortodoksyjnych treści było tylko pretekstem (ansa), nie zaś główną przyczyną (causa) zaistnienia denuncjacji. Pretekst ten pełnił funkcję propagandową i miał raczej usprawiedliwić działania plebanów w oczach biskupa i opinii publicznej niż odgrywać rzeczywistą rolę. Co więcej, sprawa była organicznie powiązana z bieżącą sytuacją w Polsce

dominikanów krakowskich w średniowieczu, w: Mendykanci (jak w przyp. 86), s. 393, 404, przyp. 76, a także M. Z d a n e k, Inkwizytorzy, s. 230-232, nr 3, 5 (choć przytoczył je wcześniej t e n ż e, Szkoły, s. 171, przyp. 7). Pozostawili oni lukę pomiędzy działalnością inkwizytorską Jana z Polski (według M. Zdanka 1422-1428/29; według P. Krasa 1422-1429/30) oraz Mikołaja z Brześcia (według M. Zdanka 1440-1463; według P. Krasa 1451-1463).

${ }^{121}$ P. K r a s, Działalność inkwizycyjna, s. 394-395.

122 Jednym z przyłapanych na posiadaniu tego typu literatury był Wincenty, późniejszy pleban w Żydowie, który z tego powodu ściągnął na siebie ekskomunikę, zob. Bullarium Poloniae, t. V, wyd. I. Sułkowska-Kuraś, S. Kuraś, Roma 1995, nr 790; P. K r a s, Husyci, s. 278; t e n że, Działalność inkwizycyjna, s. 404.

${ }^{123}$ J. K ł o c z o w s k i, Polska prowincja, s. 77 (tam starsza literatura).

${ }^{124}$ M. Z d a n e k, Inkwizytorzy, s. 231-232, nr 5. 
i wywołanymi przez nią emocjami społecznymi. Zastanówmy się zatem krótko, co mogło rozpalać umysły krakowskiego duchowieństwa w $1421 \mathrm{r}$.

W Rocznikach Jana Długosza pod rokiem 1421 wyróżniają się trzy tematy: sprawy matrymonialne królewny Jadwigi i króla Władysława, kontakty króla Władysława z husyckimi Czechami oraz budowanie sojuszy przeciwko Krzyżakom ${ }^{125}$. Zatrzymajmy się przy drugim zagadnieniu, które zapewne było żywo dyskutowane w kręgach uniwersyteckich i kościelnych. Po śmierci Wacława IV w 1419 r. umiarkowani husyci zaproponowali koronę królowi polskiemu ${ }^{126}$. W 1420 r. posłowie czescy dwukrotnie spotykali się z Jagiełłą, który dyplomatycznie unikał jednoznacznej odpowiedzi. Dopiero w lutym 1421 r., po oficjalnej wizycie panów czeskich na Litwie, definitywnie oddalił ofertę tronu praskiego, ale nie zerwał z nimi kontaktów. Na decyzję króla, obok powodów czysto politycznych, wpływ miały również kwestie religijne. Liczył bowiem na to, że uda się doprowadzić do jakiegoś porozumienia husytów z Kościołem rzymskim. Już w marcu tegoż roku, w oktawie Wielkanocy, a zatem kilka dni po wygłoszeni przez Mikołaja z Brześcia kontrowersyjnego kazania, poselstwo husyckie zjechało do Krakowa z misją polityczną i aby nawiązać kontakt z miejscowym uniwersytetem. W tym celu reprezentanci Uniwersytetu Praskiego Jan Kardynał i angielski wiklefista Piotr Payne - zwrócili się z dość śmiałą prośbą do krakowskiego rektora Jakuba z Zaborowa o wyznaczenie publicznego miejsca, w którym mogliby przeprowadzić dysputę na temat czterech artykułów praskich. Rektor, idąc za wskazaniami biskupów gnieźnieńskiego, krakowskiego, poznańskiego i płockiego, odrzucił tę petycję i odesłał proszących wprost do Stolicy Apostolskiej. Odmowa nie powstrzymała jednak posłów husyckich przed upublicznieniem w Krakowie artykułów praskich. Przedstawili je in publica audiencia u samego królala ${ }^{127}$. Opisane wyżej wydarzenie z wiosny 1421 r. jest tylko jednym z wielu przykładów antyhusyckiego nastawienia profesorów Uniwersytetu Krakowskiego ${ }^{128}$. Już dwa lata później (1423) władze uniwersyteckie wprowadziły do uroczystej przysięgi składanej przez studentów rektorowi ustęp o tym, że przysięgający nie podziela poglądów Husa ${ }^{129}$.

Polski episkopat starał się nie tylko ograniczyć wpływy husytyzmu na Uniwersytecie Krakowskim, ale również chronić przed „czeską herezją” wiernych w całym

125 Joannis Dlugossii Annales seu cronicae incliti Regni Poloniae, lib. XI, Warszawa 2000, s. $143-157$.

126 J. N i k o d e m, Polska i Litwa wobec husyckich Czech w latach 1420-1433, Poznań 2004, s. 180-263; T. G r a ff, Hierarchia kościelna państwa jagiellońskiego wobec problematyki czeskiej w pierwszej połowie XV wieku, w: Wspólnoty małe i duże w społeczeństwach Czech i Polski w średniowieczu i w czasach wczesnonowożytnych, Kraków 2010, s. 123-130; J. Gry g i e 1, Zygmunt Korybutowicz. Litewski książę w husyckich Czechach (ok. 1395 wrzesień 1435), Kraków 2016, s. 11-37.

${ }_{127}$ M. M a r k o w s k i, Stanowisko Uniwersytetu Krakowskiego wobec petycji husyckiej z 1421 roku, Materiały i Studia Zakładu Historii Filozofii Starożytnej i Średniowiecznej 4, 1965, s. 354-360; K. O ż ó g, Uczeni, s. 300; J. N i k o d e m, Polska, s. 229. Warto wspomnieć, że pochodząca z lat trzydziestych XV w. kopia traktatu pt. Portae inferi Stefana Palecza, zawierającego informacje o przybyciu poselstwa husyckiego do Krakowa w 1421 r., znajduje się również w Archiwum Dominikanów Krakowskich, Mss. LV 14, k. 190r-204v.

${ }_{128}$ K. O żó g, Uczeni, s. 299-308.

129 Tamże, s. 299. 
Królestwie. Akcja ta była przede wszystkim odpowiedzią na wezwanie zawarte w bulli Inter cunctas papieża Marcina V (22 II 1418), by ścigać zwolenników Jana Wiklefa i Jana Husa ${ }^{130}$. W 1420 r. arcybiskup Mikołaj Trąba zwołał najpierw do Wielunia (styczeń), a później do Kalisza (wrzesień) synod prowincjalny metropolii gnieźnieńskiej ${ }^{131}$. W obradach brali udział również biskup krakowski Wojciech Jastrzębiec i Stanisław ze Skarbimierza. Ten ostatni należał do grona ,ekspertów synodalnych”, odpowiedzialnych za uporządkowanie wcześniejszych ustaw i redakcję 72 artykułów nowych statutów $^{132}$. Jednym z tematów obrad było zagrożenie husyckie i temu problemowi poświęcono w statutach dwa artykuły: De haereticis i Remedia contra haereticos ${ }^{133}$. W pierwszym z nich przypomniano, że obowiązkiem biskupa i inkwizytora było chronienie wiernych przed błędem i herezją. Dlatego też powinni oni wszelkimi sposobami wyszukiwać, sądzić i karać heretyków. Drugi artykuł zawierał z kolei ośmiopunktowy program zwalczania ,podejrzanej nowej nauki” (doctrina nova suspecta), czyli przede wszystkim husytyzmu. $Z$ perspektywy naszego studium na uwagę zasługują dwa punkty, których głównymi adresatami byli plebani. Pierwszym remedium przeciwko herezji było wyczulenie na jakiekolwiek nowinki doktrynalne, które głosiliby clerici vel laici et persone utriusque sexus. W razie uzasadnionych podejrzeń plebani byli zobowiązani w sposób dyskretny (secrete) zawiadomić o tym swoich przełożonych. Winni również zachęcać parafian do informowania o wszelkich podejrzeniach. Remedia zakazywały plebanom zapraszania i przyjmowania do swoich parafii podejrzanych kaznodziejów. Ostatni punkt, z którego mieli korzystać biskup, oficjał lub inkwizytor, zawierał wezwanie, by stosowali wszelkie środki prawne w ściganiu i karaniu heretyków. Postanowienia synodu stworzyły prawne podstawy walki z husytyzmem, która stała się odtąd jednym z priorytetów duszpasterskich w polskim Kościele.

Po zamknięciu jesienią 1420 r. synodu prowincjalnego biskupi podjęli się uporządkowania własnego prawa ${ }^{134}$. Jeszcze w tym roku Wojciech Jastrzębiec zwołał synod diecezjalny i ogłosił własne statuty, będące logiczną konsekwencją ustawodawstwa wieluńsko-kaliskiego ${ }^{135}$. Ich lektura nie pozostawia żadnych wątpliwości, że biskup Wojciech - jak pisał Władysław Kłapkowski - „nienawidzi husytyzmu całą duszą i kiedy wypadnie mu o nim mówić, cisną mu się na usta najsilniejsze wyrażenia: przewrotność, perfidia, zaraza"136. Już w trzecim artykule zauważył, że quidam heretici kwestionują transsubstancjację i dlatego konieczne jest przypomnienie ortodoksyjnej doktryny Kościoła ${ }^{137}$. Dalej z kolei przestrzegł duchowieństwo,

${ }^{130}$ Sacrorum conciliorum nova et amplissima collectio, wyd. J.D. Mansi, t. XXVII, Venetiis 1784, kol. 1204-1215.

${ }^{131}$ P. Kra s, Husyci, s. 212-215.

132 K. O ż ó g, Uczeni, s. 300.

133 Statuty synodalne wieluńsko-kaliskie Mikołaja Trąby z r. 1420, wyd. B. Ulanowski, J. Fijałek, A. Vetulani, Kraków 1951, s. 94-96, art. 4-5; zob. P. K r a s, Husyci, s. 212-215.

${ }^{134}$ L. Z y g n e r, Działalność synodalna arcybiskupa Mikołaja Trąby, w: Piśmienność pragmatyczna - edytorstwo źródeł historycznych - archiwistyka, Toruń 2015, s. 218-226.

${ }_{135}$ Zob. wyżej, przyp. 14, a także G. L i c h o ń c z a k - N u r e k, Wojciech herbu Jastrzębiec, s. 110 .

${ }^{136}$ W. Kła p k o w s k i, Działalność kościelna biskupa Wojciecha Jastrzębca, Warszawa 1932, s. 34.

${ }^{137}$ Statuta Alberti, s. 66, art. 3. 
by nie głosiło kazań w domach prywatnych, gdyż mogłoby to zrodzić podejrzenie sympatyzowania $z$ heretykami, i nakazał, by nie pozwalano na głoszenie kazań podejrzanym kaznodziejom, a już pod żadnym warunkiem - świeckim ${ }^{138}$. Biskup krakowski w swojej antyhusyckiej gorliwości poszedł krok dalej niż wspomniane statuty prowincjalne i zarządził wyszukiwanie i usuwanie błędów doktrynalnych nawet $\mathrm{w}$ księgach liturgicznych. W statutach diecezjalnych przedstawione zostały błędne i heretyckie fragmenty rubryk mszalnych na liturgię Wielkiego Piątku i Soboty wraz z ich teologiczną korektą ${ }^{139}$. Aby uniknąć fermentum heresis hussitarum, biskup zarządził m.in. usunięcie $\mathrm{z}$ mszałów przepisów zabraniających udzielania komunii św. nowo ochrzczonym dzieciom ${ }^{140}$.

Najprawdopodobniej już na początku 1421 r. krakowscy plebani mieli dostęp do uchwał statutów wieluńsko-kaliskich oraz krakowskich. Kopie tych dokumentów miały być bowiem złożone w katedrze i kościołach kolegiackich, archiprezbiterzy zaś byli zobowiązani do sporządzenia poświadczonych urzędowo odpisów i przekazywania ich plebanom $^{141}$. Ci natomiast w swojej parafii upubliczniali statuty albo przez wywieszanie na ścianach lub drzwiach kościołów, albo odczytanie w ramach nabożeństw ${ }^{142}$. Fakt, że treść statutów idealnie współgrała z ówczesnymi nastrojami społecznymi, sytuacją polityczną oraz debatami teologicznymi, z pewnością nie pozostał bez wpływu na ich recepcję w kręgach kościelnych. Ich wydźwięk i aktualność zostały jeszcze wzmocnione, gdy na wiosnę 1421 r. posłowie husyccy przybyli do Krakowa i próbowali rozpowszechniać artykuły praskie. Wszystko wskazywało na to, że zagrożenie herezją Jana Husa - tak jak przewidywali biskupi oraz ojcowie synodalni - stało się realne i domagało się stanowczej, natychmiastowej reakcji przede wszystkim ze strony duchowieństwa. Antyheretycka atmosfera udzieliła się wszystkim. Mikołaj z Brześcia tak bardzo przejął się zaistniałą sytuacją (oraz rolą kaznodziei inkwizycyjnego), że zaczął nazywać heretykami i husytami nawet skonfliktowanych z nim plebanów. Z kolei plebani poruszeni tak poważnymi oskarżeniami i publiczną krytyką ich postępowania, dostrzegli w zachowaniu i słowach dominikanina przewrotnego heretyka. Wiadomo bowiem, że jedną z charakterystycznych cech ruchu husyckiego było krytykowanie kleru ${ }^{143}$. Kiedy zatem usłyszeli wielkoczwartkowe antyheretyckie

138 Tamże, art. 15 , s. 78 .

139 Tamże, s. 82-83, art. 19. Na przełomie 1429 i 1430 r. Wojciech Jastrzębiec, już jako arcybiskup, na synodzie prowincjalnym w Łęczycy powrócił do kwestii poprawy w mszałach rubryk na oficjum Wielkiego Piątku. Głównym ekspertem i autorem zamian był dominikanin Jan z Ząbkowic, zob. A. Z a j c h o w s k a, Między uniwersytetem a zakonem. Biografia i spuścizna pisarska Jana z Ząbkowic (+1446), Warszawa 2013, s. 56, 206-209.

140 Statuta Alberti, s. 83, art. 19; o sporach o komunię niemowląt zob. J. S a li j, Główne kontrowersje teologiczne wokół komunii niemowląt, Warszawa 1982, s. 52-86.

${ }^{141}$ Concilia Poloniae. Źródła i studia historyczne, t. X, opr. J. Sawicki, Wrocław 1963, s. 121-123; P. K r a s, Husyci, s. 217.

142 Tamże, s. 82-83; T. G a ł u s z k a, Dominikanie i spory, s. 13-14. W następnych latach kolejni biskupi krakowscy będą nakazywali plebanom posiadanie własnych egzemplarzy statutów i odczytywanie ich przynajmniej dwa razy w roku, zob. Statuty synodalne krakowskie Zbigniewa Oleśnickiego (1436, 1446), wyd. S. Zachorowski, Kraków 1915, s. 54; Statuta Thomae Strzępiński, wyd. U. Heyzmann, w: Starodawne prawa polskiego pomniki, t. IV, Kraków 1875, s. 113-114.

${ }^{143}$ P. K r a s, Husyci, s. 174. 
kazanie dominikanina, znaleźli wreszcie doskonały pretekst, by złożyć denuncjację. Czy chodziło im tylko o czystość doktryny Kościoła i nawrócenie brata Mikołaja? Bynajmniej. Jak zobaczymy, denuncjacja ta była w rzeczywistości kolejną odsłoną w odwiecznym konflikcie mendykantów z klerem parafialnym, głównie o posługę duszpasterską (cura animarum).

\section{TREŚĆ DENUNCJACJI I ODPOWIEDZI DOMINIKANINA}

Zapewne zaraz po Wielkanocy 1421 r. (23 marca) plebani przygotowali doniesienie na dominikańskiego kaznodzieję, zawierające listę kontrowersyjnych, ich zdaniem, jego wypowiedzi, i przedstawili je wikariuszowi biskupiemu Stanisławowi ze Skarbimierza. On natomiast przygotował skierowany do biskupa krakowskiego list denuncjacyjny, zawierający wykaz dziewięciu artykułów, wśród których - jak ocenił - jedne były przeciwne prawu kościelnemu, inne gorszące i obraźliwe, a wreszcie jeden - podejrzany o herezję. Artykuły te i odpowiedzi dominikanina oraz ogłoszone przez niego konkluzje, ze względu na bogactwo tematów i liczbę wątków, wymagają osobnych analiz. Dlatego też przedstawię tylko kilka obserwacji i komentarzy historyczno-prawno-teologicznych.

a) Articuli iuri contrarii (art. 1-2, 5-6; ad 1-2, 5-6; con. 1, 3, 5-6)

Nie będzie przesadą stwierdzenie, że Stanisławowi ze Skarbimierza udało się w czterech krótkich opiniach prawnych streścić długą i burzliwą średniowieczną debatę na temat prawa zakonników do słuchania spowiedzi ${ }^{144}$. Każda z przytoczonych wypowiedzi Mikołaja z Brześcia była dla krakowskiego uczonego punktem wyjścia do zaprezentowania jakiejś kwestii spornej i miejsca zapalnego. Już w pierwszym artykule swojej denuncjacji Stanisław przywołał niewątpliwie najważniejszy dokument regulujący współpracę duchownych w zakresie pracy duszpasterskiej -Dudum, w którym przytoczono bullę Bonifacego VIII Super cathedram $^{145}$. Dominikanin, według relacji plebanów, miał publicznie głosić, że to zakonnicy mają większą władzę w zakresie spowiedzi wiernych niż duchowieństwo diecezjalne. Oczywiście twierdzenie tego typu było niezgodne z nakazem wyrażonym w dekrecie Dudum, w którym stwierdzano jasno, że mendykanci mają takie same uprawienia w zakresie rozgrzeszania jak plebani, czyli z wyłączeniem rezerwat biskupich i papieskich ${ }^{146}$. Dla Stanisława był to wystarczający dowód, że skoro dominikanin lekceważy tak podstawowe normy prawne, to z pewnością nie szanuje on również innych, bardziej szczegółowych przepisów kościelnych. Dominikanin natomiast, odpowiadając krótko na takie oskarżenie, ujawnił inteligencję i spryt. Nie zaprzeczył bowiem, że z jego ust padły słowa o większej władzy spowiedniczej zakonników niż kleru diecezjalnego, ale - jak wyjaśnił - chodziło mu wyłącznie o większy zasięg ich posługi.

144 J. T u re k, Spory dominikanów, s. 387-430; T. G a ł u s z k a, Dominikanie i spory, s. 3-22 (tu obfita literatura).

145 Dokumenty soborów powszechnych, t. II, opr. A. Baron, H. Pietras, Kraków 2003, s. 546-555, nr 10.

146 Tamże, s. 552-553, nr 10,8b. 
Zakonnicy bowiem mogli spowiadać każdego penitenta, plebani natomiast jedynie swoich parafian.

Czy jednak rzeczywiście każdy wierny mógł bez pozwolenia swojego plebana spowiadać się np. u dominikanów? Na początku piątego artykułu denuncjacji odnajdujemy rzekomą odpowiedź Mikołaja na powyższą kwestię: parafianie nie są zobowiązani do posiadania jakiegokolwiek specjalnego pozwolenia (licentia confitendi) od swojego biskupa i plebana, ale mogą bezpośrednio przychodzić do dominikanów i otrzymywać u nich rozgrzeszenie. W ocenie Stanisława wypowiedź w tym brzmieniu była błędna, a jeżeli byłaby nadal podtrzymywana przez pozwanego, to nawet heretycka. Co ciekawe, zupełnie przemilczał on główną kontrowersję zawartą w opinii dominikanina, czyli możliwość przystępowania do spowiedzi u zakonników bez licencji od plebana, a skierował uwagę na inny temat, mianowicie licencji, jaką powinni posiadać dominikanie. Z kolei Mikołaj w swojej odpowiedzi stwierdził krótko, że wystarczy sprawdzić, co „mówią prawa” (iura dicunt). Pojawiają się więc kolejne dwie kwestie: dlaczego autor denuncjacji nie ustosunkował się do problemu licentia confitendi? O jakich prawach mówił Mikołaj z Brześcia?

Problem posiadania przez parafian licentiae confitendi pojawił się wraz z ogłoszeniem przez Sobór Laterański IV dekretu XXI: Omnis utriusque sexus, w którym nakazano: „Jeśli ktoś ze słusznej przyczyny chciałby wyznawać grzechy innemu kapłanowi (alieno sacerdoti), niech prosi i otrzyma pozwolenie (licentiam) od własnego kapłana (a proprio sacerdote)"147. Jeszcze w XIII w. rozpoczęła się debata, czy kapłani zakonni są alieni, czy też proprii w stosunku do parafian. Debata ta - co warto podkreślić - nigdy nie została definitywnie rozstrzygnięta ani przez późniejsze sobory, ani orzeczenia papieskie ${ }^{148}$. Papieże starali się raczej regulować współpracę pomiędzy duchownymi, a głos w dyskusji zabierali dopiero wówczas, gdy pojawiały się ewidentne błędy interpretacyjne. Tak było choćby w sprawie wspomnianego również przez Stanisława ze Skarbimierza - mistrza paryskiego Jana de Polliaco, który przyjmował wąskie tłumaczenie sformułowania proprius sacerdos, jako odnoszące się tylko do plebana. W lipcu 1321 r. papież Jan XXII ogłosił bullę Vas electionis, w której uznał za błędne trzy jego twierdzenia: że grzechy wyznane przed zakonnikiem należy raz jeszcze powtórzyć przed plebanem, że ani papież, ani nawet Bóg nie może zmienić postanowień soborowych odnośnie do obowiązku corocznej spowiedzi przed własnym plebanem i że papież nie może dać pozwolenia na wyspowiadanie parafian przez innych kapłanów bez konieczności powtórzenia spowiedzi przed własnym plebanem ${ }^{149}$. Dokument Jana XXII w żaden sposób nie kończył całej kontrowersji, ale przynajmniej wskazywał ślepe uliczki w toczonych sporach oraz znacząco wzbogacał kanon tekstów potwierdzających prawo zakonników do słuchania spowiedzi.

Dyskusje toczyły się nie tylko na temat prawa zakonników do spowiadania parafian, ale również prawa parafian do spowiadania się u zakonników. Generalnie spowiedź poza parafią bez specjalnej licencji od plebana lub biskupa była zakazana przez prawo kościelne, a przez niektórych duchownych traktowana nawet jako grzech

147 Tamże, s. 259, nr 21,3.

148 T. G a ł u s z k a, Dominikanie i spory, s. 4-10.

149 Łacińska edycja bulli Vas electionis w: tamże, s. 18-19. 
duchowego cudzołóstwa ${ }^{150}$. Trzeba jednak zaznaczyć, że przepisy te nie precyzowały, czy obejmują one również spowiedź u mendykantów. Żadnych wątpliwości w interesującej nas kwestii nie mieli natomiast teologowie, choć - jak zobaczymy - ich opinie bywały skrajnie różne. Henryk z Gandawy, mistrz paryski i autor poczytnego w średniowieczu Tractatus super facto praelatorum et fratrum ${ }^{151}$, starał się wszelkimi sposobami udowodnić, że warunkiem ważnej spowiedzi u zakonnika jest posiadanie przez penitenta specjalnej zgody od swego plebana. Głównym autorytetem potwierdzającym swoją tezę uczynił komentarz prawny Henryka z Suzy, który zwrócił uwagę, że w sytuacji spowiedzi u mendykantów requirenda est licentia sacerdotis parochialis. Henryk z Suzy jednak nie sprecyzował, czy miał na myśli zgodę wydaną mendykantom czy parafianom ${ }^{152}$. Henryk z Gandawy zaproponował zatem swoją interpretację: quod istud liceat sine sua licentia, intelligo obtinenda, et hoc non pro fratre ut possit absolvere, sed potius pro subdito ut possit a fratre absolvi ${ }^{153}$. Z kolei z taką interpretacją zupełnie nie zgadzał się Ryszard z Middletown. Wskazał on na konstytucję Klemensa IV Quidam temere sentientes z 1265 oraz bullę Marcina IV Ad fructus uberes z $1281 \mathrm{r}$. jako oficjalne dokumenty papieskie, dające mendykantom pełną władzę spowiedniczą wobec wiernych, a co za tym idzie, również otwierające parafianom pełny dostęp do posługi braci ${ }^{154}$.

Wymóg posiadania licentia confitendi był również wielokrotnie powtarzany w polskich ustawach partykularnych ${ }^{155}$. Co więcej, tutejsze władze kościelne nie ograniczały się tylko do przypomnienia ogólnych norm, ale zajęły się również tak szczegółowymi kwestiami, jak właśnie prawo parafian do spowiedzi u mendykantów. W 1420 r. na wspomnianym już synodzie diecezji krakowskiej ogłoszono, że pleban przystępując do słuchania spowiedzi, musi w pierwszej kolejności spytać penitenta, czy ten należy do jego parafii lub czy posiada odpowiednie pozwolenia z własnej parafii ${ }^{156}$. Natomiast jeżeli parafianin wyraził chęć wyspowiadania się u zakonników, mógł to uczynić bez jakiejkolwiek zgody ze strony swojego plebana: Tertio, quod parochiani quorumcumque rectorum volentes fratribus presentatis secundum formam iuris confiteri, de necessitate non oportet, ut requirant licenciam a suis sacerdotibus. Nam privilegiati sunt a iure vel ab homine, et habent licenciam confessiones fidelium libere audiendi ${ }^{157}$. Warto podkreślić, że zacytowany wyżej przepis nie ma analogii w żadnym znanym zbiorze średniowiecznych statutów synodalnych

${ }_{150}$ J. Avrile, À propos du ,proprius sacerdos”. Quelques réflexions sur les pouvoirs du prêtre de paroisse, w: Proceedings of the Fifth International Congress of Medieval Canon Law, Salamanca 21-25 September 1976, Città del Vaticano 1980, s. 471.

${ }^{151}$ Henricus de Gandavo, Tractatus super facto praelatorum et fratrum (Quodlibet XII, quaestio 31), wyd. L. Hödl, M. Haverals, Leuven 1989, s. 5-25.

${ }^{152}$ Henricus de Segusio, In quintum Decretalium librum commentaria, tit. 38, c. 12, Venetiis 1581, k. 102v, nr 22; Henricus de Gandavo, Tractatus, s. 12, w. 29-33.

153 Tamże, s. 12, w. 33-35.

${ }^{154}$ Fr. Richardi de Mediavilla quaestio disputata de privilegio Martini papae IV, wyd. F. M. Delorme, Quaracchi 1925, s. 72.

155 I. S k i e r s k a, Obowiązek mszalny w średniowiecznej Polsce, Warszawa 2003, s. 243 244.

156 Statuta Alberti, s. 71, art. 7.

157 Tamże, s. 84, art. 20. 
w metropolii gnieźnieńskiej. Dopiero w świetle tych kilku obserwacji możemy zrozumieć, dlaczego Stanisław ze Skarbimierza nie odniósł się w ogóle do istoty wypowiedzi dominikanina, ale skierował uwagę na inny aspekt doniesienia. On sam bowiem, jako zapewne redaktor statutów krakowskich, wiedział doskonale, że sprawa jest już rozstrzygnięta i brat Mikołaj mógł legalnie głosić takie treści. Jasna jest również krótka odpowiedź dominikanina, który po prostu zachęcił autora denuncjacji do zobaczenia, co „mówią prawa”.

Stanisław, recenzując piąte doniesienie, zwrócił uwagę na inne niebezpieczeństwo, które kryło się w tezie Mikołaja z Brześcia - wypowiedź dominikanina mogła rodzić u słuchaczy wrażenie, że wszyscy zakonnicy posiadający święcenia mogą ważnie spowiadać wiernych. Mikołaj bowiem nie zaznaczył, że uprawnionymi do słuchania spowiedzi są tylko ci bracia, którzy przeszli odpowiednią procedurę i otrzymali jurysdykcję od biskupa diecezjalnego. Bez względu na posiadane przez mendykantów różne przywileje papieskie, w sprawach sakramentu pokuty podlegają oni władzom diecezji. Mówiąc o procedurze udzielania jurysdykcji, Skarbimierczyk miał na myśli rozporządzenie z dekretu Dudum, opisujące powoływanie spowiedników zakonnych w diecezji. Modus procedendi był następujący: przełożeni mendykantów wybierali spośród braci odpowiednich kandydatów i przedstawiali ich biskupowi, który uwzględniając potrzeby diecezji, mógł udzielić przedstawionym pozwolenia na spowiadanie (licentia audiendi) $)^{158}$. Stanisław stanowczo zaznaczył, że zakonnicy, którzy nie zostali przedstawieni ani nie uzyskali pozwolenia, nie mogą podejmować posługi spowiedniczej. Uprzedzając jakby ewentualną krytykę ze strony zakonników, odradzał ponadto używania jako argumentu sprawy mistrza Jana de Polliaco. Trafnie zauważył, że ta czternastowieczna kontrowersja dotyczyła przede wszystkim problemu powtórzenia spowiedzi odbytej u zakonników. Nie można wykluczyć, że Mikołaj z Brześcia w swoich kazaniach odwoływał się do bulli Vas electionis, a może nawet publicznie pokazywał jej kopię z 1330 r., przechowywaną po dziś dzień w dominikańskim archiwum w Krakowie ${ }^{159}$.

Do tematu zakonnych spowiedników Stanisław powrócił jeszcze w szóstym artykule. Mikołaj z Brześcia miał powiedzieć, że plebani zakazują swoim parafianom spowiadać się poza parafią nie z powodu szczególnej troski o ich zbawienie, ale chęci sprzedaży im mszy i nabożeństw. Według Skarbimierczyka dominikanin, wydając tak surową ocenę, nie wziął pod uwagę, że plebani - zgodnie z Pismem Świętym oraz prawem kościelnym - „odpowiadają własną krwią” za dobro i zbawienie parafian. Dlatego też rozsądnie (rationabiliter) postępują, jeżeli zabraniają wiernym spowiadania się u kapłanów, którzy nie posiadają odpowiedniej licencji. Przyznał jednak, że rzeczywiście plebani nie powinni ani nie mogą utrudniać posługi spowiednikom, którzy otrzymali pozwolenie od biskupa. Tym jednak, co autor denuncjacji uznał za najgorsze w wypowiedzi Mikołaja, to niesprawiedliwa generalizacja - tak jakby wszyscy plebani byli złymi duchownymi. Dla Stanisława takie uogólnienie było nieprawdziwe i gorszące. Warto zauważyć, że równie krytyczna wypowiedź dominikanina na temat plebanów została przywołana także w drugim artykule. Tym

${ }^{158}$ Dokumenty soborów, t. II, s. 551-553, nr 10,6-10,8b.

159 Zob. wyżej, przyp. 149. 
razem Mikołaj miał stwierdzić wprost, że głównym powodem kontrowersji wokół słuchania spowiedzi jest chciwość plebanów. Dla Stanisława tak otwarte piętnowanie, może i prawdziwych, przewin innych duchownych było zarówno nieprzyzwoite, jak i niezgodne z kulturą prawną. Uczony przypomniał jedną z rudymentarnych zasad prawnych, że w dochodzeniu sprawiedliwości należy zastosować w pierwszej kolejności zwykłe środki prawne (iuris remedia ordinaria), dominikanin zaś od razu zastosował remedium extraordinarium ${ }^{160}$.

Mikołaj z Brześcia, odnosząc się do drugiego i szóstego artykułu denuncjacji, nie zaprzeczył, że komentował na ambonie zachowania oraz decyzje plebanów odnośnie do licentia confitendi ich parafian. Zaznaczył jednak, że wyrażane przez niego opinie nie miały formy sądów kategorycznych, ale hipotetycznych. W rzeczywistości bowiem miał powiedzieć, że gdyby plebani miłowali swoich parafian, to nie przeszkadzaliby im poszukiwać lepszych spowiedników. Natomiast dotychczasowe zachowanie plebanów rodziło przypuszczenie, że kierują się jedynie chciwością, czego dowodem było nakładanie na penitentów pokut pieniężnych, tj. zamawiania w kościele parafialnym intencji mszalnych. Powyższe sprostowanie było oficjalnym stanowiskiem Mikołaja wobec zarzutów przedstawionych w obu artykułach.

Ogłoszone przez Mikołaja z Brześcia publice coram populo konkluzje, dotyczące „zarzutów przeciwnych prawu”, możemy niewątpliwie uznać za idealne rozstrzygnięcie zaistniałego sporu. Z pewnością były one korzystne zarówno dla dominikanina, jak i Stanisława ze Skarbimierza, a także dla biskupa Wojciecha Jastrzębca. Jak pamiętamy, cztery konkluzje zawierają przytoczony prawie w całości czwarty punkt z 20 artykułu statutów krakowskich z 1420 r. Okazało się zatem, że ogłoszone zaledwie kilka miesięcy wcześniej akta synodalne stanowią doskonałe narzędzie w rozwiązywaniu bieżących problemów i zgodnie z zamysłem ustawodawcy skutecznie regulują funkcjonowanie Kościoła krakowskiego. Mikołaj z Brześcia zapewne z zadowoleniem odczytał konkluzje trzecią i piątą, zawierające następujące tezy: plebani popełniają grzech, jeżeli zabraniają parafianom przystępowania do spowiedzi u zakonnych licencjonowanych spowiedników, a nawet stają się heretykami, gdyby twierdzili, że inni kapłani posiadający pozwolenie biskupa nie mają prawa spowiadać ich parafian; jeżeli wierni chcą wyspowiadać się u mendykantów, nie muszą prosić o specjalne pozwolenie od plebana. Stanisław ze Skarbimierza i składający denuncjację plebani mogli poczuć się również usatysfakcjonowani, już bowiem w pierwszej konkluzji dowiedzieli się, że zakonnicy nie mają większej władzy w rozgrzeszaniu niż plebani. Z kolei w szóstej konkluzji zostało podkreślone, że skoro plebani są szczególnie odpowiedzialni za parafię, to postępują rozsądnie, sprawdzając, u kogo spowiadają się ich parafianie, oraz stanowczo zakazując korzystania im z sakramentu pokuty u nielicencjonowanych spowiedników.

b) Articuli scandalosi et offensivi (art. 3-4, 7-8; ad 3-4, 7-8; con. 2-3)

Wiemy już, że Mikołaj z Brześcia uciekał się do krzywdzących uogólnień. Jednak był to tylko jeden z licznych przykładów jego niefrasobliwości w mowie.

160 Zob. G. F. Wh a rto n, Legal Maxims, with Observations and Cases, London 1865, s. 263: Ubi cessat remedium ordinarium ibi decurritur ad extraordinarium. 
W trzecim artykule Stanisław zajął się dość oryginalną wypowiedzią dominikanina, że duchowni, którzy przeszkadzają dominikanom w posłudze duszpasterskiej, są heretykami i husytami. Jak wiadomo, temat husytów był żywo dyskutowany w Krakowie ok. 1421 r., stąd też nie dziwi obecność tego wątku w denuncjacji. Stanisław jednak w swojej opinii nie poruszył problemu poglądów Jana Husa, ale skupił się wyłącznie na przypomnieniu dwóch prostych rozróżnień. Najpierw bardzo spokojnie i rzeczowo wyjaśnił, że nie każdy podejrzany o herezję jest od razu heretykiem, ale tylko ten, kto świadomie trwa w błędnym przekonaniu. Następnie dostrzegając łatwy do zidentyfikowania błąd logiczny (tzw. paralogizm materialny), dodał, że nie każdy heretyk jest husytą, choć każdy husyta jest heretykiem. Dla Stanisława określenie husyta i heretyk nie były prostymi synonimami. Warto mocno podkreślić, że to, wydawałoby się, zdroworozsądkowe rozróżnienie i troska o precyzję terminologiczną były czymś wręcz niespotykanym w piętnastowiecznym piśmiennictwie. Przytoczmy tutaj ciekawą obserwację Stanisława Byliny: „Praktyka sądowa konsekwentnie utrwalała utożsamienie pojęcia heretyka z husytą i herezji z husytyzmem - -. Zauważmy, że wspomniane utożsamienie funkcjonowało w różnych warstwach kultury piętnastowiecznej; wymowne jest to, że glosatorzy tekstów łacińskich słowa hereticus, heretici uzupełniali słowami husz, huszovye. Ludzie świeccy zeznający w sądach kościelnych używali tych określeń wymiennie, nie mając wątpliwości co do tego, że będą zrozumiani"'161. W wypowiedzi Mikołaja ujawniła się po raz kolejny (i nie ostatni) tendencja do generalizacji oraz braku precyzji. Jednak jeszcze bardziej zdumiewająca jest reakcja dominikanina na powyższe doniesienie. W swojej odpowiedzi nie tylko kompletnie zignorował uwagi Stanisława, ale raz jeszcze powtórzył, że heretyk i husyta to synonimy, gdyż jeden i drugi podważają autortetet papieża oraz udzielone przez niego przywileje. W konsekwencji również plebani kwestionujący prawo mendykantów do posługi spowiedniczej są heretykami i... husytami. Dopiero w tekście konkluzji przyznał, że użycie tych obelg w stosunku do plebanów było przesadne (excessiue), o ile - zgodnie z nakazem synodu krakowskiego z 1420 r. - nie będą oni podważać autorytetu spowiedników posiadających ważną licencję.

W denuncjacji przytoczono jeszcze inną obelgę Mikołaja w stosunku do plebanów. Podczas kazania miał ogłosić, że kłamią oni jak psy. Stanisław ze Skarbimierza oczywiście zgorszył się tymi słowami, aczkolwiek potraktował dominikanina stosunkowo łagodnie. Odwołując się do tekstu biblijnego, stwierdził, że te same usta ewanglicznego kaznodziei, które błogosławią Boga, nie mogą wypowiadać przekleństw. Czytając opinię Stanisława, możemy odnieść wrażenie, że z nieznanych nam powodów nie wykorzystał przeciwko dominikaninowi całego „,potencjału” drzemiącego w tym zarzucie. Chodziło w końcu o przestępstwo zniewagi i naruszenia czci dokonane przez duchownego, za które prawo kanoniczne przewidywało surowe sankcje, włącznie z suspensą i pozbawieniem urzędu ${ }^{162}$. By lepiej zrozumieć powagę tego typu przestępstwa, warto przypomnieć, że w prawie świeckim,

161 S. B y 1 i n a, Wizerunek heretyka w Polsce późnośredniowiecznej, Odrodzenie i Reformacja w Polsce 30, 1985, s. 19.

${ }_{162}$ Decretum Gratiani, p. I, dist. 46, c. 5 (wyd. E. Friedberg, t. I, kol. 168); p. II, C. 5, q. 1, c. 1, 2 (kol. 544); C. 6, q. 1, c. 17 (kol. 558); C. 17, q. 4, c. 21 (kol. 820); Decretales Gregorii IX, lib. II, tit. 27, c. 23 (wyd. E. Friedberg, t. II, kol. 408). 
np. statutach Kazimierza Wielkiego, za obrazę czci rycerskiej wyznaczano podobną karę jak za zabicie rycerza, czyli 60 grzywien. Osoba dopuszczająca się zniewagi słownej (iniuria verbalis) musiała poza karą pieniężną odwołać zarzut za pomocą formuły „com mówił, łgałem jak pies” ${ }^{163}$. Wbrew niektórym opiniom polskie prawo nie przewidywało jednak kary odszczekiwania zniewag pod stołem psim głosem ${ }^{164}$.

Jeżeli nawet Mikołaj z Brześcia nie byłby zmuszony „odszczekać” swoich obelg, to ewidentnie uświadomił sobie ciężar oskarżeń pod swoim adresem. Było już jednak za późno na zaprzeczanie lub odwoływanie słów, których użył w swoim kazaniu. Dlatego też w swojej odpowiedzi przyjął inną, dość ryzykowną, linię obrony. Postanowił mianowicie wykazać, że plebani jak najbardziej zasłużyli na nazwanie ich psami. Idąc za Biblią, Glosą i Wincentym z Beauvais, przyjął skrajnie negatywną interpretację psa jako obrazu oszczerców, krzywidzicieli, plotkarzy, niszczycieli prawa i dobrego imienia innych ludzi ${ }^{165}$. Opis ten, zdaniem Mikołaja, doskonale pasował do plebanów, którzy przychodzili na jego kazania, łapali go za słowa, plotkowali, oczerniali go wobec osób świeckich, chodzili po mieście i rozpowszechniali fałszywe informacje na jego temat, a nawet nazywali heretykiem. W tej sytuacji dominikanin doszedł do wniosku, że pozostało mu już tylko jedno, raczej kontrowersyjne, rozwiązanie - ogłosić publicznie, że plebani „łżą jak psy”.

Jednak nie tylko obelgi Mikołaja zostały uznane przez Stanisława za skandaliczne i obraźliwe. Wypowiedź, która najbardziej oburzyła Skarbimierczyka - o czym już kilkukrotnie wspominałem - dotyczyła krytyki kadry uniwersyteckiej. Mikołaj wobec tego zarzutu zareagował równie stanowczo i emocjonalnie, jak sam Stanisław, choć niewątpliwie nie tak elokwentnie i poetycko jak tamten. Dominikanin stanowczo zaprzeczył prawdziwości tego doniesienia i raz jeszcze obwinił plebanów o ignorację i złą wolę. Podana przez niego odpowiedź jest o tyle istotna z perspektywy naszego studium, że pozwala definitywnie odrzucić przedstawione wyżej hipotezy o rzekomych napięciach i walkach między środowiskiem Uniwersytetu Krakowskiego i dominikańskim studium generalnym w Krakowie w pierwszej połowie XV w. Okazuje się, że było wręcz przeciwnie. Analizowany tekst wprost potwierdza duży szacunek i zaufanie dominikanów do tutejszych profesorów.

W siódmym i ósmym artykule swojej denuncjacji Stanisław ze Skarbimierza nie przytaczał już żadnych wypowiedzi dominikanina, ale ograniczył się do stwierdzenia, że zarówno język, styl i generalnie treść kazań dominikanina, jak i jego zachowanie nie licowały z godnością kaznodziei i były po prostu skandaliczne. Jako swego rodzaju

${ }^{163}$ I. Z g o 1 i ń s k i, Zniesławienie w polskim prawie karnym. Zagadnienia teorii i praktyki, Warszawa 2013, s. 34-37; A. B e r e z a, Przestępstwa przeciwko czci i nietyklaności cielesnej w dawnej Polsce, w: Przestępstwa przeciwko czci i nietyklaności cielesnej, Warszawa 2013, s. 32-50 (tu obfita literatura); zob. też przyp. następny.

164 Według Jana Długosza na taką właśnie karę został skazany w 1389 r. Gniewosz z Dalewic za zniesławienie królowej Jadwigi (Joannis Dlugossii Annales seu cronicae incliti Regni Poloniae, lib. X, Warszawa 1985, s. 177; zob. B. Pr z y b y s z e w s k i, Jadwiga i Wilhelm, Analecta Cracoviensia 7, 1975, s. 141-143; J. N i k o d e m, Gniewosz - Jadwiga - Wilhelm. Krytyka przekazu Annales Jana Długosza, Przegląd Historyczny 98, 2007, s. 175-195).

165 Zob. M. W i 1 s k a, Biały piesek w kulturze dworskiej późnego średniowiecza, w: Ludzie - Kościół - wierzenia. Studia z dziejów kultury i społeczeństwa Europy Środkowej (średniowiecze - wczesna nowożytność), Warszawa 2001, s. 463-473. 
podsumowanie listy zarzutów i ostrzeżenie dla Mikołaja autor denuncjacji wybrał jeden cytat z - co znamienne - wybitnie „dominikańskiej” Ewangelii według św. Mateusza $^{166}$ : „Biada człowiekowi, przez którego przychodzi zgorszenie” (Mt 18, 7).

Nie ulega wątpliwości, że Mikołaj z Brześcia, rozwiązując osobiste konflikty z plebanami w trakcie publicznego głoszenia kazań, nadużył swojej pozycji kaznodziei i wywołał zgorszenie wśród swoich słuchaczy. Dlatego też nie dziwi treść drugiej z ogłoszonych przez niego konkluzji. Nie próbował już usprawiedliwiać swojego zachowania, ale ogłosił coram populo, że zakonnik, który używał takich słów (w domyśle - jak przytoczone w denuncjacji) i stosował niesprawiedliwe generalizacje (w domyśle - odnośnie do plebanów), zgrzeszył i zasługuje na karę. Warto zauważyć, że autor tej konkluzji zrobił wszystko, by miała ona formę ogólnoobowiązującej i uroczystej uchwały, tak jakby chciał on „dopisać” kolejny artykuł do krakowskich statutów synodalnych z 1420 r. Autor konkluzji, jak już pisałem wyżej ${ }^{167}$, wyjaśniając motywy działania zakonnika, przytoczył przeredagowany fragment z 20 artykułu tych statutów - ex fomite odii uel zelo ultionis. Co szczególnie intersujące, w oficjalnym tekście statutów fraza ta odnosiła się nie do mendykantów, ale właśnie wprost do plebanów, którzy przeszkadzają braciom w posłudze spowiedniczej. Ten niewątpliwie sprytny zabieg redaktorski potwierdza nasze wcześniejsze przypuszczenie, że tekst konkluzji przedstawionych przez dominikanina powstał raczej w kancelarii Stanisława ze Skarbimierza niż w celi zakonnej Mikołaja z Brześcia.

Articuli scandalosi et offensiui okazały się zatem prawdziwe i Mikołaj wyraził gotowość przyjęcia kary. Z jaką karą mógł się liczyć? Średniowieczni dominikanie posiadali bardzo rozbudownay system penitencjarny, opisany dokładnie w kilku ostatnich rozdziałach pierwszej dysktynkcji konstytucji zakonnych ${ }^{168}$. Prawo wyróżniało cztery rodzaje wykroczeń (culpae): lekkie (leviores), ciężkie (graves), cięższe (graviores) i najcięższe (gravissimae). Przypadek Mikołaja, w zależności od interpretacji jego przełożonych, mógł być rozpatrywany jako wykroczenie lekkie albo ciężkie. W katalogu wykroczeń lekkich odnajdujemy kazus zakonnika, który w trakcie kazań mówi rzeczy błahe i niepotrzebe (otiosa). Kara za tego rodzaju zachowanie była bardzo łagodna i polegała na odmówieniu jednego psalmu ${ }^{169}$. Z kolei wykroczeniem ciężkim było kłócenie się z innymi w obecności świeckich, obrona własnego lub cudzego grzechu, a wreszcie używanie niestosownego języka i przekleństw. Za te wykroczenia zakonnik mógł otrzymać karę cielesną w postaci trzydniowego postu o chlebie i wodzie ${ }^{170}$. Łatwo zauważyć, że lista culpae graves dobrze opisuje

${ }^{166}$ Zob. T. Gałuszka, „Super Psalmum XXIII”. Badania nad Biblią w XIII wieku, Kraków 2005, s. 139-140.

167 Zob. wyżej, przyp. 103.

168 Constitutiones antiquae Ordinis Fratrum Praedicatorum, dist. I, c. 21-25, w: De oudste constitutes van de dominicanen, wyd. A. H. Thomas, Leuven 1965, s. 331-339. Na temat systemu penitencjarnego dominikanów polskich w średniowieczu zob. T. G a ł u s z k a, Kara więzienia, s. 65-79.

169 Constitutiones, dist. 1, c. 21 (s. 332, w. 25-26, 30-32): Si in predicationem vadens otiosa locutus fuerit vel agerit - - pro singulis harum culparum iniungatur pro pena petenti veniam unus psalmus.

170 Tamże, c. 22 (s. 334, w. 2-3, 7-10): Si quis inhoneste in audientia secularium cum aliquo contenderit - - si quis culpam suam vel alterius defenderit - - si in illum, a quo clamatus 
przewinienia brata Mikołaja. Nie sposób jednak stwierdzić, czy władze zakonne w ogóle zastosowały wobec byłego prowincjała ten właśnie przepis prawa zakonnego.

c) Articulus de fide suspectus (art. 9; ad 9; con. 7)

Dziewiąty artykuł denuncjacji mocno wyróżniał się na tle pozostałych zarzutów, zarówno objętością, jak i użytymi autorytetami, a przede wszystkim tematyką. Tym razem nie chodziło bowiem o sprawy prawne, pastoralne ani obyczajowe, ale kwestie najpoważniejszą - podejrzenie o herezję. Według przedstawionych przez plebanów doniesień brat Mikołaj w Wielki Czwartek miał powiedzieć, że Ciało Chrystusa (Corpus Christi) w trakcie Eucharystii przyjmowane jest przez wiernych na wzór zwykłego posiłku (velud aliter cibus), czyli jest gryzione, przeżuwane, połykane, aż wreszcie przechodzi do żołądka. Stanisław nie tylko nie pominął ani jednego z wyżej przedstawionych etapów przyjmowania pokarmu, lecz w sposób wręcz fizjologiczny podkreślił każdy z nich, tak jakby chciał uzmysłowić czytelnikowi powagę błędu dominikańskiego kaznodziei. Nie ulega wątpliwości, że tego rodzaju twierdzenie musiało zszokować każdego, kto posiadał chociaż podstawowe przygotowanie teologiczne. Trudno jest również sobie wyobrazić, by Mikołaj z Brześcia rzeczywiście głosił tego rodzaju niedorzeczne poglądy. Z drugiej jednak strony moglibyśmy zapytać: czy plebani kłamaliby w aż tak poważnej materii, jaką jest sakrament Eucharystii? Zagadkę tę rozwiązuje dopiero wyjaśnienie podane przez dominikanina w jego odpowiedzi. Zanim jednak sięgniemy do jego tekstu, warto krótko przyjrzeć się opinii prawno-teologicznej przygotowanej przez Stanisława ze Skarbimierza.

Krakowski uczony punktem wyjścia i odniesienia w tym artykule uczynił - jak już wspominałem - dzieło Ryszarda z Middletown. W pierwszej kolejności przytoczył jego typologię spożywania Ciała Chrystusa (manducatio): cielesne, sakramentalne i duchowe ${ }^{171}$. Pierwsze (manducatio carnalis) dotyczyło naturalnego procesu przyjmowania, trawienia i wydalania postaci (species) chleba i wina eucharystycznego, pod którymi kryło się prawdziwe Ciało Chrystusa. Manducatio sacramentalis odnosi się do spożycia Ciała Chrystusa pod postacią sakramentu: Ciało Chrystusa jest dopóty w człowieku, dopóki trwają postaci sakramentalne. Wreszcie manducatio spiritualis polega na zjednoczeniu przez miłość i wiarę z ciałem mistycznym Chrystusa, czyli

est, vel in quemlibet alium minas vel maledicta seu verba inordinata et irreligiosa malitiose invexisse deprehensus fuerit.

171 Zob. wyżej, przyp. 73 i odpowiadający mu tekst. Warto zauważyć, że nawiązania do typologii Ryszarda $\mathrm{z}$ Middletown odnajdujemy również w statutach synodalnych diecezji krakowskiej z 1420 r. Manducant tamen istud sacramentum quidam sacramentaliter, et ita boni sicut mali; spiritualiter, et ita soli boni. Ille vero manducat spiritualiter, qui in unitate Christi et ecclesie, quam sacramentum significat, manet; et sic spiritualiter manducare, est ecclesie incorporari (Statuta Alberti, s. 66, art. 3). Dotychczas nie udało się zidentyfikować autora (jednego lub wielu) części pastoralnej statutów (art. 1-18). K. O ż ó g, Uczeni, s. 301, przypuszczał, że dużą rolę w synodzie krakowskim odegrał Stanisław ze Skarbimierza. Poczynione w niniejszym studium obserwacje, zwłaszcza dostrzeżenie bezpośrednich związków twórczości Ryszarda z Middletown z pisarstwem Stanisława ze Skarbimierza z ok. 1421 r., pozwalają postawić wysoce prawdopodobną hipotezę, że Stanisław brał czynny udział nie tylko w pracach synodu, lecz także w przygotowaniu tekstu statutów. 
Kościołem. Typologia zaproponowana przez franciszkańskiego teologa ma dwie podstawowe zalety: prostotę i wydobycie aspektu eklezjalnego w przypadku spożywania duchowego ${ }^{172}$. Stanisław, idąc za wykładem Ryszarda, przypomniał, na czym polega spożywanie sakramentalne. Wbrew temu, co miał mówić brat Mikołaj, nie można łamać i gryźć Ciała Chrystusa w jego prawdziwej postaci, jest on bowiem nieskończony i niepodlegający cierpieniu. Fizjologicznym procesom podlegają jedynie postacie sakramentalne chleba i wina. Brak szacunku do tego fundamentalnego rozróżnienia Stanisław otwarcie nazywa hereticum et insanium. Co więcej, według Stanisława wypowiedź dominikanina dowodzi, że dla tego kaznodziei spożywanie komunii św. i jedzenie posiłków było identyczną czynnością. Był to zarzut poważny i milcząco sugerował, że dominikanin nie spełnia, podobnie jak dzieci czy umysłowo chorzy, pierwszego warunku przystępowania do Eucharystii ${ }^{173}$. Stanisław podsumował całą swoją recenzję jednym, acz znaczącym słowem - scandalum.

Mikołaj z Brześcia po przeczytaniu tego doniesienia i opinii Stanisława zapewne pojął, że nastąpiło wielkie nieporozumienie, a jego własne słowa nie tyle nawet zostały przeinaczone, ile kompletnie opacznie zinterpretowane. Wielkoczwartkowe kazanie dominikanina nie było bowiem typowym dominikańskim sermo de Corpore Christi $^{174}$, ale elementem większej akcji kaznodziejskiej, mającej na celu zwalczanie „,nowych herezji”, czyli husytyzmu i wiklefizmu. Mikołaj postanowił przedstawić i obalić jedną dość oryginalną herezję: Ciało Chrystusa w momencie zetknięcia się z ustami komunikowanego przestaje istnieć pod postaciami eucharystycznymi. Możemy się tylko domyślać, że dominikanin, wykazując błąd tej doktryny, zbyt mocno zaakcentował tezę, że obecność Chrystusa w hostii jest realna i trwała, nawet gdy wierny ją pogryzie, przeżuje i połknie. Najprawdopodobniej jednak zapomniał wspomnieć, że procesy fizjologiczne dotyczą wyłącznie postaci sakramentalnych, nie zaś Ciała Chrystusa, które pozostaje nietknięte. Ewidentnie gorliwość i retoryka kaznodziejska wzięły tu górę nad precyzją teologiczną. Dopiero w swojej odpowiedzi w pełni ortodoksyjnie i jednoznacznie stwierdził, idąc wiernie za wykładem Tomasza z Akwinu, że nawet gdy Ciało Chrystusa spożywane jest przez grzesznika, to trwa ono dopóty, dopóki trwają postaci eucharystyczne.

172 Dominikański teolog Tomasz z Akwinu wyróżnił manducatio sacramentalis oraz spiritualis, aczkolwiek w przypadku spożywania duchowego, pisał jeszcze o kolejnych dwóch typach właściwych ludziom i aniołom. W przypadku manducatio spiritualis Akwinata - inaczej niż Ryszard z Middletown - mówił wprost o bezpośrednim zjednoczeniu z Chrystusem (Thomas de Aquino, Summa theologiae, pars III, q. 80, a. 1-2, s. 228-230).

173 Warunek ten został przytoczony expressis verbis $\mathrm{w}$ krakowskich statutach synodalnych z 1420 r.: Item nec pueris usu racionis vel discrecionis carentibus, qui non possunt discernere inter cibum spiritualem et corporalem (Statuta Alberti, s. 66, art. 3). Na temat warunków przystępowania do komunii św. zob. I. S k i e r s k a, Obowiązek, s. 261-270; B. C e s e a u, „Sancta sanctis”. Normes et gestes de la commmunion entre Antiquité et haut Moyen Âge, w: Pratiques de l'eucharistie dans les Églises d'Orient et d'Occident (Antiquité et Moyen Âge), t. I, Paris 2009, s. 378-379.

${ }_{174}$ Zob. A. Z a j c how s k a, „Desiderium et reverentia”. Godne i niegodne przyjmowanie Komunii świętej w świetle średniowiecznych kazań „de Corpore Christi” z późnośredniowiecznych rękopisów bibliotek polskiej prowincji zakonu Braci Kaznodziejów, w: Między teologią a duszpasterstwem powszechnym na ziemiach Korony doby przedtrydenckiej. Dziedzictwo średniowiecza i wyzwania XV-XVI wieku, Warszawa 2017, s. 16-60. 
Kilku słów komentarza wymaga sama herezja wspomniana przez Mikołaja. Genezy tego poglądu należy poszukiwać już w XI w. Wówczas to francuski teo$\log$ i filozof Berengariusz z Tours zaczął głosić, że w trakcie konsekracji mszalnej nie następuje transsubstancjacja, a substancje chleba i wina pozostają niezmienne. Chrystus jest obecny jedynie symbolicznie w chlebie i winie, nie zaś realnie jako chleb i wino. Jednym z argumentów użytych przez tego teologa była obserwacja, że hipotetycznie może zaistnieć sytuacja, że konsekrowana hostia zostanie zjedzona przez zwierzę (np. mysz) lub, co gorsza, człowieka w stanie grzechu ciężkiego. Czy zatem zwierzę spożyłoby realne Ciało Chrystusa? Czy Bóg dopuściłby do aż tak wielkiej profanacji? Berengariusz negatywnie ustosunkował się do takiej możliwości, twierdząc, że eucharystyczny chleb i wino to tylko sakramentalne symbole. Pogląd ten został potępiony przez liczne synody, ale kazus hostii zjedzonej przez mysz lub grzesznika na stałe zagościł w grupie klasycznych zarzutów przeciwko nauce o transsubstancjacji ${ }^{175}$. W XIII w. Tomasz z Akwinu w Summie teologii poświęcił temu problemowi nawet osobny artykuł. Czytamy tam: Quidam antiqui erraverunt, dicentes quod corpus Christi-- cito labiis peccatoris figitur, tam cito sub speciebus sacramentalibus desinit esse corpus Christi. Sed hoc est erroneum ${ }^{176}$. Z tekstu tego - jak pamiętamy - skorzystał również Mikołaj z Brześcia w trakcie pisania swej odpowiedzi. O tezach i argumentacji Berengariusza z Tours na nowo zrobiło się głośno w XIV w. za sprawą Jana Wiklefa i jego doktryny symbolicznej obecności Chrystusa w Eucharystii ${ }^{177}$. Angielski teolog, przywołując kilkakrotnie „kazus myszy”, stanowczo odrzucał transsubstancjację ${ }^{178}$. Dodajmy, że według Wiklefa głównymi propagatorami tej - jak pisał - „fałszywej doktryny” byli bracia dominikanie ${ }^{179}$. Wkrótce Wiklef pozyskał gorliwego i wpływowego obrońcę w osobie Jana Husa, który co prawda nigdy nie przyjął wiklefistycznej nauki o Eucharystii, ale też nie uznawał jej za herezję. W jego ocenie była ona może nowatorska i kontrowersyjna, ale zupełnie ortodoksyjna, tym bardziej że Anglik czasami potwierdzał obecność Chrystusa w chlebie i winie zarówno vere et realiter, jak i figuraliter et virtualiter ${ }^{180}$. Oczywiście entuzjastyczne przywiązanie Husa do Wiklefa automatycznie ściągnęło na Czecha i cały ruch husycki oskarżenia o podważanie nauki Kościoła w sprawach Eucharystii ${ }^{181}$. W rzeczywistości wśród husytów było niewielu przeciwników transsubstancjacji i gromadzili się oni zwłaszcza wokół angielskiego wiklefisty Piotra

175 G. M a c y, Of Mice and Manna: „Quid Mus Sumit” as a Pastoral Question, Recherches de Théologie Ancienne et Médiévale 58, 1991, s. 157-166.

176 Zob. np. Thomas de Aquino, Summa theologiae, pars III', q. 80, a. 3, resp (s. 230).

177 Literatura zagadnienia jest bardzo bogata, zob. zwłaszcza L. K a c z m a r e k, Nauka Jana Wiklefa o tropicznej obecności Chrystusa Pana w Eucharystii, Studia Theologica Varsaviensia 7/1, 1969, s. 55-89; S. E. L a h e y, Late Medieval Eucharistic Theology, w: A Companion to the Eucharist in the Middle Ages, Leiden-Boston 2012, s. 532-539; T. M. I z b i c k i, The Eucharist in Medieval Canon Law, Cambridge 2015, s. 45-47.

178 John Wyclif, Trialogus, IV 2, 8-9, tłum. S. Lahey, Cambridge 2013, s. 197, 216, 218.

179 T. M. I z b i c k i, The Eucharist, s. 46.

180 J. S a li j, Główne kontrowersje, s. 58-59.

181 D. R. Holeto n, Wyclif's Bohemian Fate. Reflection on the Contextualization of Wyclif in Bohemia, Communio Viatorum 32, 1989, s. 209-222. 
Payne'a ${ }^{182}$. Przypomnijmy, że to właśnie on chciał w marcu 1421 r. zorganizować teologiczną dysputę z profesorami Uniwersytetu Krakowskiego.

Co ciekawe, w przededniu przyjazdu Payne’a do Krakowa, Mikołaj z Brześcia próbował obalić jeden z argumentów, stawianych przez wiklefistów przeciwko transsubstancjacji. Oczywiście nie sposób dowieść bezpośrednich związków pomiędzy tymi dwoma wydarzeniami, aczkolwiek wciąż otwartą pozostaje kwestia: dlaczego w ogóle przywołał to, jakby nie było, dość szczegółowe heretyckie twierdzenie? Przypuszczam, że nie było ono głównym tematem wielkoczwartkowej akcji kaznodziejskiej brata Mikołaja, ale stanowiło tylko jeden z wątków jego antyheretyckiego kazania na temat teologii Eucharystii ${ }^{183}$. Faktem pozostaje, że brat Mikołaj przywołał w trakcie głoszenia prawdziwe subtilia theologiae, które wymagały od kaznodziei dużej biegłości teologicznej, precyzji i umiejętności dydaktycznych, a od słuchaczy uwagi i wysiłku w zrozumieniu. Zaistnienie omawianej kontrowersji pokazuje, że niestety albo kaznodzieja, albo jego słuchacze nie spełnili powyższych warunków.

Autor konkluzji przedstawionej przez Mikołaja z Brześcia nie odnosił się już do wyjaśnień złożonych w dominikańskiej pozycji, ale ograniczył się do powtórzenia tez z opinii teologicznej Stanisława ze Skarbimierza: gryzieniu podlegają jedynie postacie chleba i wina, natomiast niezniszczalne i uwielbione Ciało Chrystusa trwa dopóty, dopóki trwają postacie sakramentalne. Konkluzja ta z pewnością usatysfakcjonowała zarówno autora listu denuncjacyjnego, jak i samego pozwanego.

\section{ZAKOŃCZENIE}

Proces denuncjacyjny z ok. 1421 r. zapewne zakończył się wraz z ogłoszeniem przez brata Mikołaja z Brześcia oficjalnych konkluzji. Dominikanina oczyszczono z zarzutów naruszenia prawa kanonicznego i podważania nauczania Kościoła, musiał jedynie popracować nad własną niefrasobliwością w mowie i radzeniem sobie w sytuacjach konfliktowych. Prawdopodobnie również zrozumiał, że bycie kaznodzieją jest czymś zgoła innym niż bycie prowincjałem, czyli nie można używać ambony do rozwiązywania problemów, czy to swoich własnych, czy też zakonnych współbraci, nawet jeżeli dotyczą tak ważnych tematów, jak praca duszpasterska i słuchanie spowiedzi. Proces nie wpłynął znacząco na dalszą karierę Mikołaja i w dalszych latach zyskał on na tyle duże zaufanie w krakowskim środowisku, że pod koniec lat dwudziestych XV w. objął nawet urząd inkwizytora papieskiego i stał się współpracownikiem biskupa Zbigniewa Oleśnickiego.

${ }^{182}$ Te n ż e, The Bohemian Eucharistic Movement in its European Context, The Bohemian Reformation and Religious Practice 1, 1996, s. 40-42; P. K r a s, Husyci, s. 185.

${ }^{183}$ Mikołaj z Brześcia mógł komentować trzy błędne tezy Wiklefa, wymienione w bulli Inter cunctas papieża Marcina V: 1. Substantia panis materialis et similiter substantia vini materialis remanent in sacramento altaris. 2. Accidentia panis non manent sine subiecto in eodem sacramento. 3. Christus non est in eodem sacramento identice et realiter in propria praesentia corporali (Sacrorum conciliorum nova et amplissima collectio, t. XXVII, kol. 1209). Pytanie o realną obecność Chrystusa w Eucharystii pojawiło się również w interrogatorium antyhusyckim z lat dwudziestych XV w., używanym na terenie metropolii gnieźnieńskiej (W. Ś w i e b o d a, Jak rozpoznać heretyka? Interrogatorium antyhusyckie używane w metropolii gnieźnieńskiej, Studia Źródłoznawcze 51, 2013, s. 129, nr 24). 
Szczęśliwie zachowany list denuncjacyjny Stanisława ze Skarbimierza oraz akta sprawy brata Mikołaja dają nam unikatową okazję, by odtworzyć i prześledzić prawie wszystkie etapy postępowania denuncjacyjnego w średniowiecznej praktyce sądu kościelnego. Teksty te stanowią także jedno z pierwszych (o ile nie pierwsze) świadectwo recepcji krakowskich statutów synodalnych z 1420 r. Wreszcie trzeba zauważyć jeszcze jeden walor analizowanego źródła - tych kilka stron zapisanych na końcu rękopisów BJ 1629 i BJ 1652 przechowało atmosferę i całą gamę emocji lokalnych osobistości i osobowości, stających w obliczu z jednej strony wewnętrznych reform krakowskiego Kościoła, inicjowanych przez biskupa Wojciecha Jastrzębca, z drugiej zaś - zewnętrznych zagrożeń ze strony husytów.

\section{ANEKS}

Aneks zawiera edycję trzech tekstów, przekazanych w rękopisach BJ 1629 (Kr1) i BJ $1652(\mathrm{Kr} 2)$ :

1) list denuncjacyjny (litterae denuntiationis) Stanisława ze Skarbimierza; stosownie do ustalonej genealogii przekazów rękopiśmiennych oraz poczynionych wyżej obserwacji, celem edycji będzie rekonstrukcja pierwowzoru rękopisów Kr1 i Kr2; w aparacie filologicznym zaznaczono wszystkie różnice pomiędzy ustalonym tekstem edycji a rękopisami;

2) odpowiedź (positiones et responsiones) Mikołaja z Brześcia; tekst zachowany tylko w rekopisie $\mathrm{Kr} 2$;

3) konkluzje (conclusiones), przedstawione przez Mikołaja z Brześcia; tekst zachowany tylko w rekopisie $\mathrm{Kr} 1$.

Dla wyróżnienia cytatów dosłownych, które zostały zasygnalizowane przez autorów, stosuję kursywę; wyróżniam nią cały fragment, nawet jeżeli niektóre wyrazy różnią się od cytowanego źródła. Pozostałe, zarówno dosłowne, jak i niedosłowne, zapożyczenia niesygalizowane przez autorów notuję w aparacie źródłowym; zostają tam oznaczone przez cf.

W edycji zastosowałem ortografię średniowieczną: w przypadku minuskulnych samogłosek $u$ i spółgłosek $v$ zostały one zredukowane do samogłoski $u$; w miejscu dwugłosek $a e, o e$, zachowana została pisownia $e$.

W celu uzyskania większej przejrzystości tekstu w edycji został wprowadzony, oprócz podziału na akapity, podział na artykuły wraz z odsyłaczami. Komentarz w aparacie edycji został sporządzony w języku łacińskim.

Zastosowane skróty:

+- addidit,

$<$ aaa $>-$ textus ab editore additus,

cancel. - cancelatus,

coni. - conicimus,

hom. - homoioteleuton,

inv. - inversit,

om. - omisit,

rep. - repetit,

suprascr. - suprascripsit. 


\section{$<$ I $>$ \\ $<$ Litterae denuntiationis Stanislai de Scarbimiria $>$}

$<\mathrm{Kr} 1$, f. 340v; Kr2, p. 521>

Reueredissime Pater, in denuntiationis materia ad ostendendum, quod articuli per me uia denuntiationis oblati quidam sunt iuri contrarii, quidam scandalosi, quidam piarum animarum offensiui, quidam de fide suspecti.

Presupponitur quod a-predicatoris euuangelici uerbum ${ }^{\text {a }}$ debet esse uelud aurum ignitum probatum et eloquium castum igne distrectionis examinatum ${ }^{1}$, b-hoc satis patet $^{-b}$. Item predicator debet esse minister pacis $^{-\mathrm{c}}$, portans oliue ramum, unctis adinstar columbe $^{2}$, ut sit Christo conformis, qui dixit suis amatoribus: Pax uobis ${ }^{3}$. Item debet loqui ad edificationem fidelium, ut non sit petra scandali et lapis offensionis ${ }^{4}$. Item rudibus et indoctis non debet alta illa presertim proponere, que capi per eos non possunt more ueritatis, que dixit: Adhuc multa habeo uobis dicere sed non potestis portare modo ${ }^{5}$. In Leuitico quippe scribitur: Vir qui fluxum seminis patitur immundus erit ${ }^{6}$, quod tractans beatus Gregorius in Pastorali, c. XV, sic inquit: Vir qui fluxum seminis sustinet, immundus asseritur, quia multiloquio subditus ex eo se inquinat, quod si recte promeret, prolem recte cogitationis edere in audientium corda potuisset; dumque incautus per loquacitatem diffluit, non ad usum generis, sed ad immunditiam semen fundit ${ }^{7}$.

$<$ Art. $1>$ Hiis premissis declaretur primus articulus, qui dicit, quod magis licet audire confessiones $<\mathrm{Kr} 2$, p. 522 $>$ fratribus predicatoribus seu monachis quam plebanis; et qui dicunt aliter populo ipsi enim decipiunt. Cuius falsitas ostenditur, quoniam secundum Ieronimum ad Riparium et Desiderium: Monachus non docentis, sed plangentis habet officium, qui uel se et $t^{\mathrm{d}}$ mundum lugeat et Domini pauidus prestoletur aduentum $^{8}$, quod uenit ex eo quia non habet officium cui cura immineat aminarum. Ex quo patet quod regulare ${ }^{\mathrm{e}-\mathrm{est}}$ istud $^{-\mathrm{e}}$ in omnibus, licet ordo predicatorum in officio predicationis sit priuilegiatus. Item patet falsitas per Clementinam Dudum, De sepulturis ${ }^{9}$, in Clementinis: per huiusmodi autem concessionem ubi non intendit papa fratribus huiusmodi ampliorem dare auctoritatem quam parochialibus sacerdotibus $^{10}$. Ex quo patet quod se equa est fratris et parochialis sacerdotis auctoritas falsum est quod magis, licet illi quam isti, cum pro isto scilicet parochiali sacerdote ius ordinarium pro illo uero priuilegium interpellet restrictum.

1 aurum...examinatum] cf. Rev 3,18; Ps 119, 140; Ps 12, 7.

2 portans...columbe] cf. Gen 8, 10-11.

3 Luc 24, 36; J 20, 21. 26.

${ }^{4}$ I P $2,8$.

${ }^{5}$ Ioh $16,12$.

${ }^{6}$ Lev 15, 2.

7 Gregorius, Regula pastoralis, p. II, c. 4 ex Decret. Grat., p. I, dist. 43, c. 1 (ed. E. Friedberg, t. I, col. 135).

${ }^{8}$ Hieronymus, Contra vigilantium liber unus, nr 15 (ed. J. P. Migne, Patrologia Latina, t. XXIII, Parisiis 1845, col. 351B), ex Decreto Gratiani, C. 16, q. 1, c. 4 (ed. E. Friedberg, t. I, col. 762).

${ }^{9}$ Constitutiones Clementinae, lib. III, tit. 7, c. 2 (ed. E. Friedberg, t. II, col. 1161-1164).

${ }^{10}$ Ibidem (col. 1163); cf. etiam Statuta Alberti Jastrzębiec episcopi Cracoviensis, art 20 [1], ed. U. Heyzmann, in: Starodawne prawa polskiego pomniki, t. IV, Kraków 1875, p. 84. 
$<$ Art. 2> Secundus quod propter auariciam plebani dicentes, quod magis liceat eis audire quam fratribus, faciunt et non propter salutem, et quod in hoc populum seducunt. Ostenditur quod ingerit conuicia. Si enim plebani in hoc excessissent, posito sed non concesso, habent iuris remedia ordinaria. Et ideo non opportebat fratrem Nicolaum ad conuicia in predicationis officio euuangelico conuolare.

$<$ Art. $3>$ Tertius articulus qui continet in effectum, quod qui passim fratribus predicatoribus inhibent sunt heretici et hussonite ${ }^{f}$ et in hoc mentiuntur ut canes. Quisquis adhunc sensum, qui fratribus putatis legitime inhibent confiteri et in hoc sedem apostolicam, que dat eis licentiam contempnunt, sunt de fide suspecti et de heresi. Non tamen proprie possunt dici heretici enim hoc duo hereticum constituunt error in ratione et pertinacia in uoluntate ${ }^{11}$. Et quod ${ }^{\mathrm{g}}$ de hussonistis addidit ex habundantia cordis ${ }^{12}$ est locutus. Non enim sequitur iste est hereticus igitur est hussonista, tamen heretici diuersitas facies habeant, licet habeant caudas adinuicem colligatas ${ }^{13}$. Illud uero, quod subiunxit: mentiuntur ut canes, ubi didicit, si enim secundum Ieronimum in Epistola ad Tytum: Michael non fuit ausus maledicere dyabolo et certe maledictionis dignissimo iudicium inferre blasfemie quanto magis homines ab omni maledicto puri esse debent. Merebatur diabolus maledictum sed per os angeli blasphemia exire non debuit ${ }^{14}$. Sic per os euuangelici predicatoris exire non debuit maledictionis conuicium ne eadem ligwa, qua benedicit Deo maledicat hominibus et ex eodem foramine emanet dulcem et amaram aquam ${ }^{15}$.

$<$ Art. 4> Quartus articulus in effectu continet licet hic fiunt doctores et magistri tamen nichil sciunt et quod ipsi uellent cum doctoribus tractare et inuenire quod est ita. Quo nititur studium per sedem apostolicam approbatum destruere; doctores et magistros, qui auctoritate apostolica creantur confundare; regi et regno in hoc quod inscios et ignaros habent pro doctoribus et magistris detrahere; populum contra uniuersitatem concitare et sedicionem facere; caritatis dulcedinem, quam habent rex ${ }^{\mathrm{h}}$, militia et populus ad eos inficere; sapiencior omnibus doctoribus apparere. Falsitas autem $^{i}$ istius patet per experientiam enim per Dei clementia sint tales, qui in Ytalia, Parisius et alibi ualentes reputari patent.

$<$ Art. 5> Quintus articulus dicit in effectu, quod non sit neccesarium quod subditi uadant ad plebanos pro licentia confitendi sed simpliciter sine omni licentia prope episcopi uel plebani uadant ad eosdem ${ }^{j}$ et ipsi uelint eos salubriter expedire. Et hic articulus sic intellectus est de fide, si defenditur, suspectus. Non enim habent materiam, in quam agerant, nisi ipsis per illorum trium alterum ministretur. Et ideo sic sentire est Sedi Apostolice, que limitare habet $\mathrm{et}^{\mathrm{k}}$ restringere, detrahere. Nec credatur, quod fermentum Iohanis de Poliaco iste contineat articulus non enim articulatur, quod confessi fratribus iterum debeant suis parochialis sacerdotibus confiteri, sed

${ }^{11}$ error...uoluntate] cf. Petrus Lombardus, Sent., lib. IV, d. XIII, c. II (ed. Colegii S. Bonaventurae, t. II, Grottaferrata 1981, p. 314-315); Guido de Baysio, Rosarium decretorum, C. XXIV, q. 3, c. XXVII (Venetiis 1480, f. 145vb).

${ }_{12}$ Mt 12, 34.

${ }^{13}$ Heretici...colligatas] cf. Decretales Gregorii, lib. V, tit. 7, c. 13, 15 (ed. E. Friedberg, t. II, col. 787, 789).

${ }^{14}$ Decretum Gratiani, P. II, C. XXIV, q. 3, c. 10 (ed. E. Friedberg I, col. 993).

15 lingwa...aquam] cf. Iac. 3, 8-11. 
hoc quod illicentiati, nec presentati possunt confessiones audire et fidelibus iniungere primas salutares.

$<$ Art. $6>$ Sixtus articulus continet, quod plebani non propter salutem subditis inhibent confiteri fratribus predicatoribus sed quod populo uendant missas et psalteria. Stant enim quod inhibere racionabiliter possunt ne confiteantur aliis quam presentatis, ipsorum enim est uidere nec pereant, enim sanguis ouium de ipsorum manibus requiratur $^{16}$, licet inhibere non debeant neque possint ne presentatis legitime confiteantur enim illud habeant ex indulto. Finis autem [Kr2, p. 523] istius articuli criminatur uniuersitatem plabanorum, in qua possunt boni esse et mali. Et ideo constat, quod pessime in hoc est ${ }^{1}$ locutus ${ }^{1}$.

$<$ Art. 7> Septimus articulus continet, quod hoc omnia furiose increpatorie cum talibus uituperiis frater Nicolaus est locutus, que uix liceret loqui in thaberna. Et hic requirit ${ }^{\mathrm{m}}$ ut puniatur in quo delinquit, ut discat tacere aliquanto tempore a docendo ${ }^{17}$, donec proficiat recte loqui, legat enim et relegat omnia uolumina doctorum, omnes scripturas nusquam inueniet sanctum et iustum hominem sic locutum.

$<$ Art. 8> Ultimus articulus continet, quod predicatio quam resumpsit aliquotiens magnum scandalum in populo generauit. Que enim edificatio discipuli potest surgere ex magistri furia, conuiciis, uituperiis? Et utique: Ve homini per quem scandalum uenit $^{18}$. Opportet igitur ut tollatur scandalum de medio, quod ex uerbis mordacibus, detractoriis, insipidis et insulsis est relictum.

$<$ Art. 9 $><$ Kr1, f. 341r $>$ Super materiam uero qua locutus est frater Nicolaus de corpore Christi. Primus articulus continet in effectu, quod corpus Christi commeditur per hominem dentibus diuiditur, masticatur, deglutitur, in stomachum uelud aliter cibus transmittitur. Pro cuius declaratione premitto, quod secundum Richardum super quartum Sententiarum: Quedam est manducatio carnalis, qua comestum masticatur et in stomachum trahitur et postea digeritur et ultimo in substantiam manducantis conuertitur et sic uere manducatur illa species sub qua realiter continetur uerum corpus Christi. Est alia manducatio sacramentalis, qua corpus uerum realiter sub specie contentum sumitur et sic sumptum masticatur et descendit in stomachum per descensum speciei, sub qua continetur corpus Christi, sub qua tamdiu continetur quam diu species in propria forma saluatur. Sed per uirtutem manducantis non ${ }^{\mathrm{n}}$ unitur ${ }^{0-}$ manducanti sed per ipsum manducans unitur-o spiritualiter Christo capiti si digne manducat. Est alia manducatio spiritualis, qua dicitur manducari, que nihil aliud est secundum eundem quam spiritualiter incorporari corpori mistico per fidem et caritatem, uel magis incorporari per augumentum fidei et caritatis que manducatio ${ }^{\mathrm{p}-}$ non conuenit ${ }^{\mathrm{p}}$ indigne suscipientibus hoc sacramentum ${ }^{19}$. Non obstat de consecratione, dist. II Ego Berengarius, super quo se fortasse fundasse uidetur ubi reuocando

${ }^{16}$ sanguis...requiratur] cf. Ez 3, 18; 33, 8, quem allegat etiam Decretales Gregorii, lib. I, tit. 31 , c. 13 (ed. E. Friedberg, t. II, col. 191).

17 discat...docendo] cf. Stanislaus de Scarbimira, Sermones de Sapientia selecti, sermo XXXIII: Praedicator enim vel doctor non debet pro aliquo scandalo falsum docere vel dicere evitando, licet possit et debeat tacere (ed. B. Chmielowska, Varsaviae 2016, p. 80, lin. 137-139).

${ }_{18}$ Mt 18, 7.

19 Richardus de Mediavilla, Super IV libros Sententiarum, lib. IV, dist. 9, a. 1, q. 1, resp. (t. IV, Brixiae 1691, p. 109a). 
errorem dicit: Verum corpus Domini nostri Ihesu Christi in ueritate manibus sacerdotum tractari et frangi et fidelium dentibus atteri ${ }^{20}$, quia illa attricio et fractio debet referri ad species, non ad uerum corpus Christi. Ille enim Berengarius fuerat infamatus, quod non credebat corpus Christi realiter contineri sub specie panis propter quod ad sui purgationem uerbis expressisius utebatur ${ }^{21}$. Alioquin si uerba Berengarii sane non intelligerentur maior esset heresis quam ipse habuit. Omnia enim hoc debent referri ad ipsas species ${ }^{r}$. Nam de corpore Christi partes non facimus, eadem decretis Qui manducat notat Glossa sub uerbo dentibus in dicto canone Ego Berengarius. Ex quibus patet quod cum, ut in secundo articulo articulatur, frater Nicolaus non fuit locutus de specibus sacramenti sed plane dixit quod Corpus Christi uelud aliter cibus comeditur, dentibus diuiditur, masticatur in stomachum transmittitur. Nec, ut articulatur in tertio articulo, fecit differentiam aliquam in hoc inter cibum materialem et celestem ${ }^{22}$. Nec ulla neccesitate ad hoc inductus ut articulatur in quarto. Nec talia loqui rudi populo fuit expediens ut articulatur in quinto. Nec excusari paterit quasi ex lapsu lingwe fuerit, sed ex proposito iteratis uicibus locutus est dicendo suprasimus, comedimus, masticauimus, diuersiuimus, deglutiximus et in stomachum sicut illum cibum transmisimus in articulatur in sexto. Et quia hoc sua presumptuosa predicatio insulsa sale distrectionis non condita magnum scandalum generauit, ut articulatur in ultimo. Concluditur quod populum scandalizauit, pias aures offendit, fidei catholice iniuriam non appendens uerba in statera fecerit.

Item ostanditur quod hoc predicatio est insana ait enim Ambrosius in libro De sacramentis: Non iste panis est qui uadit in corpus: sed panis uite eterne qui anime nostre substantiam fulcit ${ }^{23}$. Dicere ergo uadit in uentrem absolute et non habendo respectum ad species est hereticum et insanium.

Item Glossa ordinaria hunc errorem confundens in canono Non iste panis, de quo dist. II: Non incorporatur, sicut ceteri cibi, qui in stomacho digeruntur, uel non descendit in stomachum, sicut ille uel non transit in sustentationem corporis, sicut ille est enim cibus anime non corporis tamen uadunt in corpus ${ }^{24}$.

Item Augustinum in epistola ad Ireneum: Quando manducamus, partes de illo facimus. Et quia in sacramento sic fit, et norunt fideles quemadmodum manducent carnem Christi; unusquisque accipit partem suam, unde et ipsa gratia partes $<$ uocantur $>^{\text {s. }}$. Per partes manducatur, et manet integer ${ }^{25}$. Et hoc tollit uerum diuidimus nisi referatur ad species prout superius est premissum. Ex quo patet quod licet factum

${ }^{20}$ Decretum Gratiani, p. III, dist. 2, can. 42 (ed. E. Friedberg, t. I, col. 1328), quem sequitur Richardus de Mediavilla, Super IV libros Sententiarum, lib. IV, dist. 9, a. 1, q. 1, arg. 2 (p. 108b).

${ }^{21}$ Richardus de Mediavilla, Super IV libros Sententiarum, lib. IV, dist. 9, a. 1, q. 1, ad 2 (p. 109a).

${ }^{22}$ differentiam...celestem] cf. Statuta Alberti, art. 3, p. 66.

${ }^{23}$ Ambrosius, De sacramentis, lib. V, cap. 4 (ed. J. P. Migne, Patrologia Latina, t. XVI, Parisiis 1845, col. 471), ex Decreto Gratiani, p. III, dist. 2, can. 56 (ed. E. Friedberg, t. I, col. 1335).

${ }^{24}$ Glossa, [in:] Decretum Gratiani, p. III, dist. 2, can. 56 (Venetiis 1684, col. 2543).

${ }^{25}$ Augustinus, In Iohannis evangelium tractatus, 6, 56 (ed. J. P. Migne, Patrologia Latina, t. XXXV, Parisiis 1841, col. 1617), ex Decreto Gratiani, p. III, dist. 2, c. 58, 70, 75 (ed. E. Friedberg, t. I, col. 1336, 1341, 1345). 
per partes diuiditur sub illo tamen integrum corpus Christi latet glorificatum enim corpus non recipit aliquam lesionem. $<\mathrm{Kr} 2$, p. 524> Si ergo integrum est corpus Christi quando diuiditur, quando frangitur nisi quia fractum diuiditur aut species diuiditur. Et quia ad specierum notitiam rudes uix proueniunt non fecit profectum hoc predicatio sed scandalum.

${ }^{\mathrm{t}} \mathrm{Hoc}$ produco non faciendo me accusatorem, sed uestre paternitatis officium ad quod pertinet errores corrigere implorando ${ }^{-t}$.

${ }^{\mathrm{a}}$ predicator fidei catholice $\mathrm{Kr} 1, \quad{ }^{\mathrm{b}}$ que satis patent $\mathrm{Kr} 1, \quad{ }^{\mathrm{c}}$ paucis $\mathrm{Kr} 1 \mathrm{Kr} 2$ et coni., $\quad{ }^{\mathrm{d}}$ uel $\mathrm{Kr} 2$ et ipse Hieronymus (cf. app.), $\quad{ }^{e}$ inv. $\mathrm{Kr} 1, \quad{ }^{\mathrm{f}}$ hussoniste $\mathrm{Kr} 1,{ }_{\mathrm{g}}+\mathrm{ex} \mathrm{Kr} 1$ et cancel. ab ipso auctore, ${ }^{\mathrm{h}}+$ et $\mathrm{Kr} 1$ et cancel. ab ipso auctore, ${ }^{\mathrm{i}}$ om. $\mathrm{Kr} 1,{ }^{\mathrm{j}}$ eos $\mathrm{Kr} 2,{ }^{\mathrm{k}}$ om. $\mathrm{Kr} 1$, ${ }^{1}$ suprascr. $\mathrm{Kr} 1, \quad{ }^{\mathrm{l}}+\mathrm{est} \mathrm{Kr} 1$ et cancel. ab ipso auctore, ${ }^{\mathrm{m}}$ requirunt $\mathrm{Kr} 1,{ }^{\mathrm{n}}+\operatorname{dicitur}(?)$ $\mathrm{Kr} 2$ et cancel. ab ipso auctore, $\quad{ }^{\circ}$ om. hom. $\mathrm{Kr} 2,{ }^{\mathrm{p}}$ om. $\mathrm{Kr} 1,{ }^{\mathrm{r}}+($ per hom.) non ad uerum corpus Christi $\mathrm{Kr} 1$ et cancel. ab ipso auctore, s lacuna $\mathrm{Kr} 2 \mathrm{Kr} 2$ et coni. cum Augustino (cf. infra), ${ }^{\mathrm{t}}$ om. $\mathrm{Kr} 2$.

\section{$<$ II $>$ \\ $<$ Positiones et responsiones fratris Nicolai $>$}

$<\mathrm{Kr} 2$, p. 524 $>$

$<$ ad 1 $>$ Ad primum articulum dixi, quod licet audire magis confessionem fratribus predicatorum quam plebanis extensiue, quia audire possunt parochianos cuiuslibet plebani, quod plebanus non potest nisi enim suos.

$<$ ad 2> Ad secundum quod propter ipsorum auariciam faciunt et non propter salutem, ista ego non dixi sic simpliciter, sed sic dixi, quod si deligerunt salutem animarum suarum ouium non prohiberent eos querere eandem ubi melius possent; sed timeo presentium, quod non curant de salute earum ${ }^{\mathrm{a}-}$ sed de auaricia ${ }^{-\mathrm{a}}$, quia multi iniungunt penitentias peccuniales missarum uel psalteriorum et sibi ipsis faciunt eas dare.

$<$ ad 3> Ad tertium qui confiteri fratribus predicatoribus inhibent sunt heretici et huszsite quia manifeste inhibent iura canonica, quia heretici dicitur qui romane ecclesie priuilegium ab ipso summo ecclesiarum pontifico traditum auferre conatur ${ }^{26}$ destruere ut XX secunda dist., cap. 1. ut De hereticus dicitur. Quando autem dixi: mentiuntur ut canes, hoc in secundo sermone replicaui propter mendosam diffamationem, qua me coram secularibus diffamauerunt detrahendo michi et me hereticum faciendo, dicendo etc. Opportuit me uocare eos canes quia laceruerunt contra ueritate. Cum enim Apostolus dicat: Videte canes, uidete malos operarios ${ }^{27}$, et Glossa ${ }^{28}$ continua ibidem super apostolum, qui bonam famam denigrant et latrant. Et in multis locis

${ }^{26}$ Decretum Gratiani, dist. 22, c. 1 (ed. E. Friedberg, t. I, col. 73), quem etiam sequitur Thomas de Aquino, Contra impugnantes, c. 3 (ed. Leonina, t. XLI, Romae 1970, p. A68 lin. 451-454).

27 Phil. 3, 2.

${ }^{28}$ Glossa (ed. J. P. Migne, Patrologia Latina, t. CXCII, Parisiis 1855, col. 86C), quam sequitur Thomas de Aquino, Contra impugnantes, c. 24, arg. 4, ad 4 (p. A140 lin. 24-32; p. A141 lin. 132-138). 
Sacre Scripture oblocutores canes uocantur et detractore ${ }^{29}$. Et tales fuerunt isti, quia iuris ordine non seruato ad me uenerunt et in sermone me ceperunt ${ }^{30}$, me nesciente coram multis hominis diffamauerunt.

$<$ ad 4> Ad quartum, quod doctores diffamassem, sic dixi: multi fatui sacerdotes et plebani ignari nescientes scripturas male informant suos. Et tamen multi doctores sunt hic, et magistri multi, ipsi semper in ignorantia permanentes, nolunt ab eis informari quomodo se regere debeant. Et numquam ordo est infestatus per aliquem uirum doctum sed per tales fatuellos, qui sciencie deberent neccesaria sed studere pigrescunt.

$<$ ad 5> Ad quintum non est neccesarium, quod ipsi uadant pro licentia ad plebanos quia iura dicunt que committo doctoribis exponere.

$<$ ad 6> Ad sixtum, quod plebani non propter salutem inhibunt, uobis hoc iam supra dixi quia est unius articulus.

$<$ ad 7> Ad septimum, quod hoc omnia locutus est furiose increpatorie ibi crimen imponunt michi et infamiam, quia iuerunt per ciuitatem me diffamando occulte, ut quidam eorum magistri et probi uiri et prelati michi retulerunt, et illud ipsi non caritatiue sed ex inuidia et longa cordis displicentia ${ }^{31}$ fecerunt.

$<$ ad $8>$ Ad octauum, quod predicatio mea magnum scandalum generauit, istud committo omnibus doctoribus et probis uiris. Si fuit scandalum, quod ego me expurgaui de heresi et de talibus, que dicta michi sunt. Et submitto me correctioni ordinis mei. $<$ ad 9> Item super materia de corpore Christi, istam materiam predicaui a multis annis in conuentu isto propter nouas hereses, ad quas extirpandas mandatum habui a reuerendo inquisitore predicare, quod corpus Christi, ut id asserunt heretici, dum ad os reciperetur, desineret esse corpus Christi. Et id inquisitor auctoritate apostolica michi mandauerat istud predicare, quod et feci, et numquam fui impeditus ab eis pro ista materia nisi anno isto sum diffamatus, tamquam hereticus, quia ita dixi in sermone, feria quinta bona ${ }^{32}$, de corpore Christi, petitus a clericis per intimacionem michi positam ad ambonem. Et causa fuit quare dixi et fuerunt uerba mea et forma sic, sicut fui informatus, quod quilibet peccator recipit corpus Christi et masticatur et dentibus teritur ad stomachum uadit et tamdiu est factum corporis Christi quam diu sunt species panis et uini ${ }^{33}$. Et si ex hoc scandalum ortum est, quod ad mandatum feci et modo adscripta meorum emulorum iteraui, qui soli me petiuerunt. Subicio me informacioni mei ordinis.

a rep. ms.

${ }^{29}$ oblocutores...detractores] cf. Vincentius Bellovacensis, Speculum morale, lib. III, dist. 4, pars 1 (Duaci 1624, col. 787b).

30 in sermone...ceperunt] cf. Mt 22, 15.

31 cordis displicentia] cf. (Pseudo-)Thomas de Aquino, Postilla in Librum Genesim, c. 6 (Opera omnia, t. VI, Parisiis 1876, p. 51a): Mos autem hominum est, quod quando unum opus destruunt, faciunt ex cordis displicentia.

32 feria quinta bona] id est dies Coenae Domini.

${ }^{33}$ quilibet peccator...uini] cf. Thomas de Aquino, Summa theologiae, pars III ${ }^{\mathrm{a}}$, q. 80, a. 3, resp. et ad 3 (ed. Leonina, t. XII, Romae 1904, p. 230-231). 


\section{$<$ III $>$ \\ $<$ Conclusiones propositae a fratre Nicolao $>$}

$<$ Kr1, f. 341r $>$

Istas conclusiones frater Nicolaus publice coram populo proponet:

$<$ con. $1>$ Prima $<$ conclusio $>$. Frater presentatus legitime iuxta formam iuris habet tantam et non ampliorem auctoritatem quam habet parochialis sacerdos absoluendi confitentes, nisi ulterius per episcopum uel alium ad hoc potestatem habentem fratri presentato uel parochiali sacerdoti concessum ${ }^{34}$.

$<$ con. 2> Secunda conclusio. Licet predicatoris in conuentu uitia correguntur, ubi tamen ex fomite odii uel ${ }^{35}$ zelo ultionis ${ }^{36}$ descendit ad speciem expressam uel circumlocutam $^{\mathrm{a}}$, aut multitudinem absolute terminat ${ }^{\mathrm{b}}$, in qua sunt boni et mali ${ }^{37}$, peccet et est pena dignus.

$<$ con. $3>$ Tertia conclusio. Licet peccant grauiter, qui inhibent populo fratribus legitime presentatis confiteri, ex quo ius et Papa ad hoc eos licentiat ${ }^{38}$. Ego tamen in hoc excessiue dixi, quod hereticos et hussonistas appelaui, nisi quis pertinaciter asseret quod fratres presentati legitime audiendi confessiones non habeant ${ }^{39}$.

$<$ con. 4> Quartam < conclusionem > obmitto.

$<$ con. 5> Quinta conclusio. Parochniani plebanorum confessi fratribus presentatis legitime secundum formam iuris non oportet quod requirant licentiam a suis parochialis sacerdotibus, enim habeant a iure licentiam, ex quo presentati fratres et admissi a iure uel ab homine confessiones fidelium audiendi ${ }^{40}$.

$<$ con. 6> Sixta conclusio. Plebani, qui inhibent fratribus presentatis legitime confiteri non propter ipsarum salutem irracionabiliter faciunt. Illi uero, qui inhibent quod non confitenantur aliis quam presentatis rationaliter inhibent enim ad ipsos spectat uidere de omnibus ipsorum ne pereant ${ }^{41}$.

$<$ con. 7> Circa materiam sacramenti sit ista conclusio. Licet factum per partes diuiditur sub illo tamen corpus Christi latet glorificatum enim corpus non recipit aliquam lesionem ${ }^{42}$.

\footnotetext{
${ }^{34}$ Frater...concessum] cf. Statuta Alberti, art. 20, p. 84; cf. Litterae denuntiationis, art. 1 .

${ }^{35}$ ex fomite...uel] cf. Statuta Alberti, art. 20, p. 84.

${ }^{36}$ odio uel zelo ultionis] cf. Hugoccio, Summa decretorum [ad Decret. Grat., p. II, C. XXIII, q. 4, c. 1 (ed. E. Friedberg, t. I, col. 899)]: Vindicta quandoque infertur ex odio et zelo ultionis et non iusticie, quandoque infertur amore correctionis et afflictorum liberationis, laudatur a H. Walther, Häresie und päpstliche Politik: Ketzerbegriff und Ketzergesetzgebung in der Übergangsphase von der Dekretistik zur Dekretalistik, in: The Concept of Heresy in the Middle Ages (11th-13th C.), Louven 1983, p. 127, app. 90.

37 multitudinem...et mali] cf. Litterae denuntiationis, art. 6.

${ }^{38}$ Licet...eos licentiat] cf. Statuta Alberti, art. 20, p. 84

39 quis...habeant] cf. ibidem.

${ }^{40}$ Parochniani... audiendi] cf. ibidem.

${ }^{41}$ qui inhibent...pereant] cf. Litterae denuntiationis, art. 6; cf. Statuta Alberti, art. 20, p. 84-85.

${ }^{42}$ Licet...lesionem] cf. Litterae denuntiationis, art. 9.
} 
Attricio et fractio fit in specibus non in corpore $\mathrm{Christi}^{43}$, et quam diu durantur species, tam diu est ibi uerum corpus Christi ${ }^{44}$.

${ }^{\mathrm{a}}$ circumlocutiam $m s$. et coni. $\quad{ }^{\mathrm{b}}$ terminatur $m s$. et coni.

\section{BIBLIOGRAFIA}

Amielańczyk K., Zasada skargowości i zakaz orzekania ponad żądanie stron w procesie rzymskim, Gdańskie Studia Prawnicze 33, 2015.

Anzulewicz H., Um den Kodex Ms. lat. 456 der Staatsbibliothek Preußischer Kulturbesitz zu Berlin: I: Richard von Mediavilla, Franziskanische Studien 74, 1992.

Avrile J., À propos du „proprius sacerdos”. Quelques réflexions sur les pouvoirs du prêtre de paroisse, w: Proceedings of the Fifth International Congress of Medieval Canon Law, Salamanca 21-25 September 1976, Città del Vaticano 1980.

Bellini P., „Denunciatio evangelica” e „denunciatio iudicialis privata”. Un capitulo di storia disciplinare della Chiesa, Milano 1986.

Bereza A., Przestępstwa przeciwko czci i nietyklaności cielesnej w dawnej Polsce, w: Przestępstwa przeciwko czci i nietyklaności cielesnej, Warszawa 2013.

Boüard A. de, Les „conservatores et judices” de la Basilique de S. Pierre de Rome, Mélanges d'Archéologie et d'Histoire de l'Ecole française de Rome 30, 1910.

Budkowa Z., Rękopisy kazania „De bellis iustis”, w: L. Ehrlich, Polski wykład prawa wojny XV wieku. Kazanie Stanisława ze Skarbimierza „De bellis iustis”, Warszawa 1955.

Bylina S., Wizerunek heretyka w Polsce późnośredniowiecznej, Odrodzenie i Reformacja w Polsce 30, 1985.

Caldwell Ames Ch., Inkwizycja i bracia św. Dominika. Słuszne prześladowanie, tłum. A. Gomola, Poznań 2013.

Ceseau B., „Sancta sanctis”. Normes et gestes de la commmunion entre Antiquité et haut Moyen Âge, w: Pratiques de l'eucharistie dans les Églises d'Orient et d'Occident (Antiquité et Moyen Âge), t. I, Paris 2009.

Chmielowska B., Stanislas de Skarbimierz - le premier recteur de l'Université de Cracovie après le renouveau de celle-ci, Mediaevalia Philosophica Polonorum 24, 1979.

Decock W., Theologians and Contract Law: The Moral Transformation of the „Ius Commune” (ca. 1500-1650), Leiden-Boston 2013.

Dola K., Liturgia wielkiego tygodnia w katedrze wrocławskiej w XV wieku, Studia Teologiczno-Historyczne Śląska Opolskiego 7, 1979.

Domański J., Discours d'inauguration fait par Stanislas de Skarbimierz à l'occasion du renouveau de l'université de Cracovie, Mediaevalia Philosophica Polonorum 24, 1979.

Esmein E., A History of Continental Criminal Procedure: With Special Reference to France, thum. J. Simpson, Boston 1913.

Friedlander A., Processus Bernardi Delitiosi: The Trial of Father Bernard Delicieux, 3 September - 8 December 1319, Philadelphia 1996.

Gałuszka T., „Super Psalmum XXIII”. Badania nad Biblią w XIII wieku, Kraków 2005.

Gałuszka T., Dominikanie i spory wokół prawa do słuchania spowiedzi. Recepcja bulli Jana XXII „Vas electionis” w diecezji wrocławskiej w 1. połowie XIV wieku, Studia Źródłoznawcze 52, 2014.

Gałuszka T., Jan ze Schenkenfeldu - tomista inkwizytorem, w: Proces beginek świdnickich w 1332 roku. Studia historyczne i edycja łacińsko-polska, opr. P. Kras, T. Gałuszka, A. Poznański, Lublin 2017.

${ }^{43}$ Attricio...Christi] cf. ibidem. p. 66 .

${ }^{44}$ quam...Christi] cf. Positiones et responsiones fratris Nicolai, ad 9; Statuta Alberti, art. 3, 
Gałuszka T., Kara więzienia w późnośredniowiecznej polityce penitencjarnej dominikanów polskich, Kwartalnik Historyczny 117, 2010, nr 4.

Gałuszka T., Kolektor Piotr z Auvergne i plebani versus biskup Jan Grotowic i dominikanie. Studium historyczne instrumentu notarialnego z 1333 roku ze zbiorów Archivio Secreto w Watykanie, Przegląd Historyczny 105, 2014.

Gałuszka T., Mikołaja Duthorowa OP „Error condemnatus ab Ecclesia”. Dominikanie polscy wobec herezji i nowych nurtów pobożności w 1. połowie XIV wieku, Kwartalnik Historyczny $122,2014, \mathrm{nr} 1$.

Gałuszka T., Podział dominikańskich okręgów klasztornych na Kujawach w XIV wieku. Studium historyczne i edycja tekstu widymatu prowincjała Ludolfa z 1517 roku, Roczniki Historyczne 80, 2014.

Gałuszka T., Szkolnictwo konwentualne i partykularne w strukturach polskiej prowincji dominikanów XIV stulecia. Nowe ujęcie w świetle nowych źródeł, Roczniki Historyczne 78, 2012.

Graff T., Hierarchia kościelna państwa jagiellońskiego wobec problematyki czeskiej w pierwszej połowie XV wieku, w: Wspólnoty małe i duże w społeczeństwach Czech i Polski w średniowieczu i w czasach wczesnonowożytnych, Kraków 2010.

Grygiel J., Zygmunt Korybutowicz. Litewski książę w husyckich Czechach (ok. 1395 - wrzesień 1435), Kraków 2016.

Holeton D. R., The Bohemian Eucharistic Movement in its European Context, The Bohemian Reformation and Religious Practice 1, 1996.

Holeton D. R., Wyclif's Bohemian Fate. Reflection on the Contextualization of Wyclif in Bohemia, Communio Viatorum 32, 1989.

Izbicki T. M., The Eucharist in Medieval Canon Law, Cambridge 2015.

Kaczmarek K., Szkoły i studia polskich dominikanów w okresie średniowiecza, Poznań 2005.

Kaczmarek L., Nauka Jana Wiklefa o tropicznej obecności Chrystusa Pana w Eucharystii, Studia Theologica Varsaviensia 7/1, 1969.

Kalisz T., Czy w średniowieczu istnieli dominikańscy wędrowni kaznodzieje?, w: Dominikanie w czasach krucjat, katedr i herezji, Poznań 2016.

Kielar P., Mikołaj Lypoldi dominikanin magister artium I bakałarz teologii, w: Studia nad historią dominikanów w Polsce, t. I, Warszawa 1975.

Kłapkowski W., Działalność kościelna biskupa Wojciecha Jastrzębca, Warszawa 1932.

Kłoczowski J., Dominikanie polscy na Śląsku w XIII-XIV wieku, Lublin 1956.

Kłoczowski J., Polska prowincja dominikańska w średniowieczu i Rzeczypospolitej Obojga (wielu) Narodów, Poznań 2008.

Knapek E., Akta oficjalatu i wikariatu generalnego krakowskiego do połowy XVI wieku, Kraków 2010.

Kowalewicz H., Średniowieczna poezja polskich żaków, Pamiętnik Literacki 64, 1973, z. 1.

Kozłowska-Budkowa Z., Opis rękopisu BJ 1652 (maszynopis w Oddziale Rękopisów BJ). Chmielowska B., „Ars praedicandi” Stanisława ze Skarbimierza, w: Retoryka w XV wieku, Wrocław 1988.

Kras P., „Ad abolendam diversarum haeresium pravitatem”. System inkwizycyjny w średniowiecznej Europie, Lublin 2006.

Kras P., „Pastor bonus et lupi rapaces”. The polemic against Hussite doctrine in the writings of Stanisław of Skarbimierz, w: Česko-polské kazatelské vztahy ve středověku, Praha 2016.

Kras P., Dominican inquisitors in Medieval Poland (14th-15th c.), w: Praedicatores, Inquisitores, I. The Dominicans and the Medieval Inquisition. Acts of the 1st International Seminar on the Dominicans and the Inquisition. Rome, Roma 2004.

Kras P., Działalność inkwizycyjna dominikanów krakowskich w średniowieczu, w: Mendykanci w średniowiecznym Krakowie, Kraków 2007 (Studia i Źródła Dominikańskiego Instytutu Historycznego w Krakowie 4).

Kras P., Husyci w piętnastowiecznej Polsce, Lublin 1998.

Kublin G., Piśmiennictwo średniowiecznych dominikanów związanych z klasztorem w Raciborzu, Przegląd Piśmiennictwa Teologicznego 21, 2015. 
Kuraś S., Przywileje prawa niemieckiego miast i wsi malopolskich XIV-XV wieku, Wrocław 1971.

Lahey S. E., Late Medieval Eucharistic Theology, w: A Companion to the Eucharist in the Middle Ages, Leiden-Boston 2012.

Lefebvre C., Gratien et les origines de la dénonciation évangélique, De l'accusatio à la denunciatio, Studia Gratiana 4, 1956/57.

Lichończak-Nurek G., Wojciech herbu Jastrzębiec. Arcybiskup i mąż stanu, Kraków 1996.

Macy G., Of Mice and Manna: „Quid Mus Sumit” as a Pastoral Question, Recherches de Théologie Ancienne et Médiévale 58, 1991.

Markowski M., Stanowisko Uniwersytetu Krakowskiego wobec petycji husyckiej z 1421 roku, Materiały i Studia Zakładu Historii Filozofii Starożytnej i Średniowiecznej 4, 1965.

Nikodem J., Gniewosz - Jadwiga - Wilhelm: Krytyka przekazu Annales Jana Długosza, Przegląd Historyczny 98, 2007.

Nikodem J., Polska i Litwa wobec husyckich Czech w latach 1420-1433, Poznań 2004.

Nowakowski T., Idea areng dokumentów książąt polskich do połowy XIII wieku, Bydgoszcz 1999.

Ożóg K., Biskupa Wojciecha Jastrzębca „paterna sollicitudo” o Kościół krakowski. Statuty synodalne z roku 1420, w: Wojciech Jastrzębiec - dyplomata i arcybiskup, Katowice 2017 [w druku].

Ożóg K., Relacje mendykantów ze środowiskiem dworskim oraz katedralnym na Wawelu do końca XV wieku, w: Mendykanci w średniowiecznym Krakowie, Kraków 2007 (Studia i Źródła Dominikańskiego Instytutu Historycznego w Krakowie 4).

Ożóg K., Uczeni w monarchii Jadwigi Andegaweńskiej i Władysława Jagiełły (1384-1434), Kraków 2004.

Paolini L., Il „De officio inquisitionis”. La procedura inquisitoriale a Bologna e Ferrara nel Trecento, Bologna 1976.

Pennington K., Enrico da Susa, detto l'Ostiense, w: Dizionario biografico degli Italiani, t. XLII, Roma 1993.

Przybyszewski B., Jadwiga i Wilhelm, Analecta Cracoviensia 7, 1975.

Salij J., Główne kontrowersje teologiczne wokół komunii niemowląt, Warszawa 1982.

Sawicki J., Concilia Poloniae. Źródła i studia krytyczne, [t. IV:] Najdawniejsze statuty synodalne diecezji chełmskiej z XV w., Lublin 1948.

Seńko W., Piotr Wysz z Radolina (* ok. 1354 - + 1414) i jego dzieło „Speculum aureum”, Warszawa 1995.

Skierska I., Obowiązek mszalny w średniowiecznej Polsce, Warszawa 2003.

Swieżawski S., Dzieje filozofii europejskiej w XV wieku, t. IV, Warszawa 1979.

Świeboda W., Jak rozpoznać heretyka? Interrogatorium antyhusyckie używane w metropolii gnieźnieńskiej, Studia Źródłoznawcze 51, 2013.

Tatarzyński R., Stanisława ze Skarbimierza trzy mowy rekomendacyjne, Przegląd Tomistyczny 6-7, 1997

Teeuwen M., The Vocabulary of Intellectual Life in the Middle Ages, Turnhout 2003.

Torrell J.-P., Tomasz z Akwinu - człowiek i dzieło, tłum. A. Kuryś, Warszawa 2008.

Trajdos T. M., Kaznodzieje dominikańscy we Lwowie w XV w., w: Kaznodziejstwo średniowieczne - Polska na tle Europy. Teksty, atrybucje, audytorium, Warszawa 2014.

Turek J., Jan Biskupiec, prowincjał polskich dominikanów w latach 1411-1417, w: Ecclesia, regnum, fontes. Studia z dziejów średniowiecza, Warszawa 2014.

Turek J., Podział polskiej prowincji dominikanów w czasach prowincjalatu Jana Biskupca w latach 1415-1417, Przegląd Historyczny 106, 2015.

Turek J., Spory dominikanów polskiej prowincji z duchowieństwem diecezjalnym w okresie od XIII do XV wieku, Przegląd Tomistyczny 15, 2009.

Walther H., Häresie und päpstliche Politik: Ketzerbegriff und Ketzergesetzgebung in der Übergangsphase von der Dekretistik zur Dekretalistik, w: The Concept of Heresy in the Middle Ages (11th-13th C.), Louven 1983. 
Weiss A., Biskupstwa bezpośrednio zależne od Stolicy Apostolskiej w średniowiecznej Europie, Lublin 1992.

Wharton G. F., Legal Maxims, with Observations and Cases, London 1865.

Wielgus S., Consilia de Stanislas de Scarbimiria contre l'astrologue Henri Bohemus, Studia Mediewistyczne 25, 1988, z. 1.

Wilska M., Biały piesek w kulturze dworskiej późnego średniowiecza, w: Ludzie - Kościół - wierzenia. Studia z dziejów kultury i społeczeństwa Europy Środkowej (średniowiecze - wczesna nowożytność), Warszawa 2001.

Wisłocki W., Katalog rękopisów Biblioteki Uniwersytetu Jagiellońskiego, t. I, Kraków1877-1881.

Włodek Z., Stanisława ze Skarbimierza I utrakwizm husycki, Przegląd Tomistyczny 9, 2003.

Wojciechowska B., Stanisława ze Skarbimierza rozważania „o dwóch drogach, którymi podąża się do nieba", w: Ambona. Teksty o kulturze średniowiecza ofiarowane Stanisławowi Bylinie, Warszawa 2016.

Wolny J., Krakowskie środowisko katedralne w czasach Jana Długosza (1431-1480), w: Dlugossiana. Studia historyczne w pięćsetlecie śmierci Jana Długosza, Warszawa 1980.

Wójcik-Zega D., Zega W., Stanisława ze Skarbimierza kazanie uniwersyteckie „Nihil tuleritis in via", Przegląd Tomistyczny 14, 2008.

Wójcik-Zega D., Zega W., Stanisława ze Skarbimierza mowa rekomendacyjna „Ecce odor filii mei” na licencjat Macieja z Koła, Przegląd Tomistyczny 17, 2011.

Zajchowska A., „Desiderium et reverentia”. Godne i niegodne przyjmowanie Komunii świętej w świetle średniowiecznych kazań „de Corpore Christi” z późnośredniowiecznych rękopisów bibliotek polskiej prowincji zakonu Braci Kaznodziejów, w: Między teologią a duszpasterstwem powszechnym na ziemiach Korony doby przedtrydenckiej. Dziedzictwo średniowiecza i wyzwania XV-XVI wieku, Warszawa 2017.

Zajchowska A., Między uniwersytetem a zakonem. Biografia i spuścizna pisarska Jana z Ząbkowic (+1446), Warszawa 2013.

Zavalloni R., Richard de Mediavilla et la controverse sur la pluralité des formes. Textes inédits et études critiques, Louvain 1951.

Zawadzki R. M., Stanisław ze Skarbimierza, w: Polski słownik biograficzny, t. XLII (20032004).

Zawadzki R., Spuścizna pisarska Stanisława ze Skarbimierza, Kraków 1979.

Zawodzińska C., Pisma Stanisława ze Skarbimierza, pierwszego rektora UJ, w kodeksach Biblioteki Jagiellońskiej, Roczniki Biblioteczne 4, 1960.

Zdanek M., Inkwizytorzy dominikańscy w diecezji krakowskiej w średniowieczu, w: Inkwizycja papieska w Europie Środkowo-Wschodniej, Kraków 2010 (Studia i Źródła Dominikańskiego Instytutu Historycznego w Krakowie 7).

Zdanek M., Szkoły i studia dominikanów krakowskich w średniowieczu, Warszawa 2005.

Zgoliński I., Zniesławienie w polskim prawie karnym: Zagadnienia teorii i praktyki, Warszawa 2013.

Zygner L., Działalność synodalna arcybiskupa Mikołaja Trąby, w: Piśmienność pragmatyczna - edytorstwo źródeł historycznych - archiwistyka, Toruń 2015.

Zygner L., Działalność synodalna arcybiskupa Wojciecha Jastrzębca (próba retrospekcji i reinterpretacji), Studia Mazowieckie 10/24, 2015, z. 3. 


\section{Denunciation of a Dominican}

A historical study and text edition of a denunciatory letter by Stanisław of Skarbimierz and the records of the case of friar Mikołaj of Brześć (circa 1421)

\section{Summary}

The aim of this paper is an analysis and edition of three texts contained in two 15th century manuscripts from the Jagiellonian Library (BJ 1629, BJ 1652): a denunciatory letter (litterae denuntiationis) by the first rector of the reactivated Cracow University, the vicar general of the bishop, Stanisław of Skarbimierz, concerning the views proclaimed by the former provincial of Polish Dominicans, Mikołaj of Brześć; the reply (positiones et responsiones) to the accusations by Mikołaj of Brześć; conclusions (conclusiones) publicly presented by Mikołaj of Brześć. Both manuscripts contain part of the records of the denunciatory process (per denuntiationem; denuntiatio iudicalis publica), which took place in Cracow about 1421. Stanisław of Skarbimierz, when preparing his letter, accepted the function of the procurator of a group of local clergymen (sacerdotes et plebani). The letter was addressed to the bishop of Cracow, Wojciech Jastrzębiec, and contained a list of nine controversial theses, which Mikołaj of Brześć was supposedly preaching in his sermons. He claimed, inter alia, that Dominicans had greater power concerning the confession of the faithful than diocesan clergy but parish priests forbid them to confess with the Dominicans because of their greed (they wanted to sell masses and services to them); that parish priests who prevented the Dominicans from performing their ministrations, were heretics and Hussites, and concerning the privileges of the Dominicans they lied like dogs; that the Cracovian professors were incompetent; that the Body of Christ (Corpus Christi) during the Eucharist was received by the faithful like an ordinary meal (velud aliter cibus). On the basis of that litterae denuntiationis a summons was drawn, to which the monk prepared his reply (positiones et responsiones), and also lodged several allegations concerning the persons who produced the denunciation. At the last stage of the proceedings, maybe during the sitting which closed the evidentiary hearings, the Dominican publicised six general conclusions (conclusiones), probably prepared at the bishop's chancery. Their author restricted himself mainly to literally quoting fragments from the Cracovian synodal statutes of 1420 . The denunciatory process ended with the publication of the conclusions and the Dominican was found not guilty of infringement of Canon law and questioning the teachings of the Church, but he should have worked on his own insouciance in speech. The case of friar Mikołaj of Brześć is an original testimony of internal reforms in the Cracovian church and complicated relations of Polish Dominicans with diocesan clergy, as well as reactions of local clergy to the external threat of Hussitism and new theological currents. 